\title{
Photoreceptor cell death and rescue in retinal detachment and degenerations
}

\section{Citation}

Murakami, Yusuke, Shoji Notomi, Toshio Hisatomi, Toru Nakazawa, Tatsuro Ishibashi, Joan W. Miller, and Demetrios G. Vavvas. "Photoreceptor Cell Death and Rescue in Retinal Detachment and Degenerations." Progress in Retinal and Eye Research 37 (2013): 114-140.

\section{Published Version}

10.1016/j.preteyeres.2013.08.001

\section{Permanent link}

http://nrs.harvard.edu/urn-3:HUL.InstRepos:32490557

\section{Terms of Use}

This article was downloaded from Harvard University's DASH repository, and is made available under the terms and conditions applicable to Other Posted Material, as set forth at http:// nrs.harvard.edu/urn-3:HUL.InstRepos:dash.current.terms-of-use\#LAA

\section{Share Your Story}

The Harvard community has made this article openly available.

Please share how this access benefits you. Submit a story.

Accessibility 


\title{
Photoreceptor cell death and rescue in retinal detachment and degenerations
}

\author{
Yusuke Murakamia,b, Shoji Notomi ${ }^{a}, b$, Toshio Hisatomi ${ }^{\mathrm{b}}$, Toru Nakazawac ${ }^{\mathrm{c}}$, Tatsuro \\ Ishibash $^{\mathrm{b}}$, Joan W. Miller ${ }^{\mathrm{a}}$, and Demetrios G. Vavvas ${ }^{\mathrm{a}, 1}$ \\ aRetina Service, Angiogenesis Laboratory, Department of Ophthalmology, Massachusetts Eye \\ and Ear Infirmary, Harvard Medical School, Boston, Massachusetts, 02114, USA \\ bDepartment of Ophthalmology, Graduate School of Medical Sciences, Kyushu University, \\ Fukuoka, 812-8582, JAPAN \\ 'Department of Ophthalmology, Tohoku University, Graduate School of Medicine, Sendai, \\ 980-8574, JAPAN
}

\begin{abstract}
Photoreceptor cell death is the ultimate cause of vision loss in various retinal disorders, including retinal detachment (RD). Photoreceptor cell death has been thought to occur mainly through apoptosis, which is the most characterized form of programmed cell death. The caspase family of cysteine proteases plays a central role for inducing apoptosis, and in experimental models of RD, dying photoreceptor cells exhibit caspase activation; however, there is a paradox that caspase inhibition alone does not provide a sufficient protection against photoreceptor cell loss, suggesting that other mechanisms of cell death are involved. Recent accumulating evidence demonstrates that non-apoptotic forms of cell death, such as autophagy and necrosis, are also regulated by specific molecular machinery, such as those mediated by autophagy-related proteins and receptorinteracting protein kinases, respectively. Here we summarize the current knowledge of cell death signaling and its roles in photoreceptor cell death after RD and other retinal degenerative diseases. A body of studies indicate that not only apoptotic but also autophagic and necrotic signaling are involved in photoreceptor cell death, and that combined targeting of these pathways may be an effective neuroprotective strategy for retinal diseases associated with photoreceptor cell loss.
\end{abstract}

\section{Introduction}

Photoreceptor cells die when they are physically separated from the underlying retinal pigment epithelium (RPE) and choroidal vessels, which provide metabolic support to the outer layers of the retina. Retinal detachment occurs in various retinal disorders, including age-related macular degeneration (AMD) (Dunaief et al., 2002), diabetic retinopathy (Barber et al., 1998), as well as rhegmatogenous, tractional, and exudative retinal detachment (RD)

\footnotetext{
(C) 2013 The Authors, Published by Elsevier Ltd. All rights reserved.

${ }^{1}$ Corresponding author: Retina Service, Angiogenesis Laboratory, Department of Ophthalmology, Massachusetts Eye and Ear Infirmary, Harvard Medical School, 243 Charles St., Boston, Massachusetts, 02114, USA Phone: 617 573 6874 Fax 617-573-3011 demetrios_vavvas@meei.harvard.edu.

Publisher's Disclaimer: This is a PDF file of an unedited manuscript that has been accepted for publication. As a service to our customers we are providing this early version of the manuscript. The manuscript will undergo copyediting, typesetting, and review of the resulting proof before it is published in its final citable form. Please note that during the production process errors may be discovered which could affect the content, and all legal disclaimers that apply to the journal pertain.
}

Competing interests statement. The Massachusetts Eye and Ear Infirmary Institution has filed patents on the subject of neuroprotection in retinal degenerations. Y.M., J.W.M., and D.G.V. are named inventors. 
(Cook et al., 1995). Although surgery is carried out to reattach the retina, only two-fifths of patients with rhegmatogenous RD involving the macula recover 20/40 or better vision (Campo et al., 1999). In other conditions mentioned, sustained serous RD causes progressive visual decline. Although various pathological changes occur in detached retina (Anderson et al., 1981; Lewis et al., 1994; Jablonski et al., 2000), studies on experimental models and human patient samples have shown that photoreceptor cell death is immediately induced as early as 12 hours and peaks at around 2-3 days after RD (Cook et al., 1995; Hisatomi et al., 2001; Arroyo et al., 2005). Retinal imaging by optical coherence tomography have demonstrated that the microstructure of foveal photoreceptor cells is a critical factor predicting better visual function in patients who received successful RD repair (Schocket et al., 2006; Wakabayashi et al., 2009). These findings suggest that loss of photoreceptor cells may be an important cause of vision loss after RD. Photoreceptor cell death also underlies the pathology of other retinal disorders such as retinitis pigmentosa (RP) and AMD, and is the basis for visual decline. Although the causes and clinical characteristic of each retinal disorder differ, accumulating evidence suggests that some molecular pathways leading to photoreceptor cell death appear to be shared by these diseases at leaset in part. Therefore, identification of the mechanisms involved in photoreceptor cell death will be critical to developing new treatment strategies for these retinal diseases associated with photoreceptor cell loss. In the present review, we summarize the current knowledge of cell death mechanisms and their roles in RD and other retinal disorders.

\section{Classification of cell death: Apoptosis, autophagic cell death, and necrosis}

\subsection{Morphological features}

Apoptosis, autophagy, and necrosis are three major forms of cell death defined by morphological appearance (Kroemer et al., 2009; Galluzzi et al., 2012). Schweichel and Merker proposed this classification in an ultrastructural study of physiological cell death in prenatal tissues. The morphological characteristics of each form of cell death are as follows: Type I (apoptosis): condensation of the nucleus and cytoplasm, rounding-up of the cell, reduction of cellular volume, and engulfment by resident phagocyte; Type II (autophagy): formation of large inclusions (autophagosomes and autolysosomes) in the cytoplasm and lack of condensation and fragmentation of cells; Type III (necrosis): swelling of the cytoplasm and organelles, a gain in cell volume, plasma membrane rupture, and connections with the extracellular cavity (Schweichel and Merker, 1973). Although there are some exceptional criteria or nomenclature of cell death based on biochemical features, this basic threefold classification is accepted and widely used in a number of literature from the 1970s to date (Clarke, 1990).

\subsection{Genetic/Biochemical features}

In various species, cell death during normal development always appears in the same place and at the same developmental stage. In 1960s, Lockshin and Williams published a set of papers focused on "programmed cell death" based on their proposed theory that 'the cells that will die have been programmed to do so' (Lockshin and Williams, 1965). Saunders showed that the cells in the axillae of embryonic chicken wing, which would die later in development, followed the same fate even when they were explanted in tissue culture (Saunders, 1966). From these findings, researchers speculated that cell death is actively regulated at the level of genetic transcription and translation. Indeed, by the late 1960s, it was shown that physiological cell death requires RNA and protein synthesis for its execution (Tata, 1966; Lockshin, 1969; Makman et al., 1971). 
In 1972, Kerr, Wyllie and Currie highlighted a specific form of cell death, for which they coined the term apoptosis (Greek for "falling off), and suspected it as a general mechanism of controlled dell deletion (Kerr et al., 1972). Using C. elegans as a model to study the genetic basis of cell death, Ellis and Horvitz identified essential genes that control cell death during development such as ced-3 (Ellis and Horvitz, 1986). Ced-3 gene was cloned by Yuan, Horvitz and colleagues (Yuan et al., 1993), which led to the identification of mammalian homologs of the ced-3 gene, namely the caspase family of cysteine proteases (Miura et al., 1993; Li and Yuan, 2008). Accumulating evidence indicate that caspases are essential for signal transduction and execution of apoptosis during development as well as in certain diseases. However, it should be noted that caspases do not necessarily regulate all forms of apoptosis. Some mitochondrial proteins such as apoptosis-inducing factor (AIF) and endonuclease $\mathrm{G}$ were shown to induce apoptosis independently of caspases when they were released from the mitochondria (Susin et al., 1999). Calpains, cathepsins or poly(ADPribose) polymerases (PARPs) also trigger cell death in a caspase-independent manner (Krantic et al., 2007). The detailed mechanisms of caspase-dependent and -independent apoptosis and their roles in retinal degeneration are described later in this review.

Autophagy (Greek for "self-eating) is a process by which a cell's own components, such as macromolecules (e.g., proteins, lipids and nucleic acids) and organelles (e.g., mitochondria), are degraded by the lysosome (Mizushima et al., 2008). Macroautophagy (hereafter referred to autophagy) is the best-characterized autophagy pathway and involves the formation of autophagosomes and autolysosomes. The autophagosome is a double- or multi-membrane vacuole that sequesters cytoplasmic materials and fuses with lysosomes to form autolysosomes, where its content is degraded. It is induced by nutrient starvation in order to provide recycled energy and eliminate damaged organelles (Schworer and Mortimore, 1979). From the genetic screening of autophagy-defective mutants in yeast, Tsukada, Ohsumi and colleagues discovered a set of autophagy-related (Atg) genes, most of which have mammalian homologues (Tsukada and Ohsumi, 1993; Mizushima et al., 1998). Although previous morphological studies identified accumulation of numerous autophagosomes/autolysosomes in dying cells, the roles of autophagy, either promoting or protecting against cell death, has been controversial. In specific circumstances, autophagy appears to mediate cell death via excessive self-degradation (Yu et al., 2004). Nonetheless, accumulating evidence has shown that autophagy is crucial for cell survival by regulating the turnover of intracellular contents in normal and most pathological conditions (Mizushima and Levine, 2010).

Although necrosis (Greek for "dead") was traditionally thought to be an uncontrolled process of cell death, it is now known to also have regulated components in certain instances. This regulated type of necrosis was discovered from the extensive studies of death receptor-induced cell death. Laster and colleagues observed that TNF-a caused not only apoptosis but also necrosis depending on cell types (Laster et al., 1988). Intriguingly, Vercammen and colleagues demonstrated that when death receptor-induced apoptosis is suppressed by caspase inhibitors, murine L929 fibrosarcoma cells undergo an alternative necrotic cell death (Vercammen et al., 1998a; Vercammen et al., 1998b). Twelve years later, Holler and colleagues identified that this death receptor-induced necrosis is mediated by the activation of receptor-interacting protein 1 (RIP1) (Holler et al., 2000). Furthermore, three independent studies recently discovered that RIP3 is a crucial regulator of RIP1 kinase activation and subsequent necrosis (Cho et al., 2009; He et al., 2009; Zhang et al., 2009a). These advances in understanding the molecular basis of necrosis have revealed previously unrecognized roles of necrosis in physiological and pathological processes, including retinal degeneration (Vandenabeele et al., 2010). This RIP kinase-dependent regulated necrosis is termed as 'necroptosis' or 'programmed necrosis' (Chan et al., 2003; Degterev et al., 2005).

Prog Retin Eye Res. Author manuscript; available in PMC 2014 November 01. 
However, in order to avoid confusion, we here express it descriptively as 'RIP kinasedependent necrosis' according to recent studies (Green et al., 2011; Oberst et al., 2011).

\subsection{Methods of detection and classification}

Because apoptosis, autophagy, and necrosis were originally defined based on their morphological appearance (particularly in ultrastructural studies), it is evident that morphological analysis using transmission electron microscopy (TEM) is one of the most sensitive and direct methods to classify cell death. Although TEM has been used less frequently in the laboratory over the past decades, it is still useful to know what kind of cell death is involved in disease processes (Eskelinen, 2008). However, limitations exist in a morphological study by itself. First, morphological features do not indicate the involvement of specific molecules among multiple death signaling pathways, albeit they may suggest a link to certain pathways. Second, the information for functional aspects of cell death is unavailable from morphological studies.

Several biochemical methods to detect cell death have been developed. Cell death can be easily labeled and quantified by these methods; however, it is still difficult to specifically discriminate the types of cell death. For example, whereas detection of phosphatidylserine (PS) exposure is known as a marker of early apoptosis, necrotic cells also externalize PS before membrane permeabilization in certain cells (Krysko et al., 2004). TUNEL staining, which was initially thought to specifically detect apoptotic cells, also labels DNA breaks in necrotic cells (Grasl-Kraupp et al., 1995; Artus et al., 2010). Conversely, cell-impermeable dye such as propidium iodide, which is used to label necrotic cells, also detects late-stage apoptosis. Biochemical detection of key molecular events in apoptosis (e.g., caspase cleavage), necrosis (e.g., RIP kinase phosphorylation), and autophagic cell death [e.g., light chain 3 (LC3) conversion], or inhibition of these molecules by pharmacological or genetic approaches, may provide significant information for the specific roles of each molecule and cell death type. However, because these molecular pathways are not completely independent and are activated redundantly during death execution, it is important to use care when interpreting the results from these experiments. For example, even if caspase inhibition fails to prevent cell death, it does not necessarily mean that caspases are not involved in cell death; other caspase-independent pathways may compensate for caspase inhibition. Moreover, because one molecule can mediate diverse and sometimes opposite effects in multiple cells and conditions, it is complex to define the precise biological mechanisms behind the phenotypes induced by its blockade. For experiments using small compound inhibitors, the target specificity and off-target effects should always be carefully considered.

Taken together, each of the morphological and biochemical approaches has advantages and drawbacks in detecting and classifying cell death. Therefore, a combination of these techniques should be considered for proper classification and better understanding of cell death.

\section{Caspase-dependent apoptosis}

\subsection{Caspase signaling}

3.1.1. Initiator and effector caspases-While there is only one caspase (CED-3) in $C$. elegans, multiple caspases are found in more complex organisms ( $\mathrm{Li}$ and Yuan, 2008). Thus far, 10 murine caspases (caspase-1, -2, -3, -6, -7, -8, -9, -11, -12 and -14) and 11 human caspases (caspase- $1,-2,-3,-4,-5,-6,-7,-8,-9,-10$ and -14 ) have been identified. The human caspase- 4 and -5 are functional orthologs of mouse caspase- 11 and -12 , whereas human caspase-10 is not present in the mouse genome. The remaining caspases with the same numbers in human and mouse are functional orthologs of each other. 
The caspase family proteins consist of the prodomain, p20 and p10 subunits. They are produced as catalytically inactive zymogens and their activation requires proteolytic cleavage at specific Asp residues and/or allosteric conformational changes. According to the length of the prodomains, caspases are divided into initiator caspases (caspase- $1,-2,-4,-5$, $-8,-9,-10,-11$, and -12 ) and effector caspases (caspase-3, -6 , and -7 ). Initiator caspases have long prodomains containing protein-protein interaction motifs, i.e. the death effector domain (DED) in caspase- 8 and -10 or the caspase recruitment domain (CARD) in caspase-1, -2, -4, $-5,-9,-11$, and -12. In contrast, effector caspases possess short prodomains (Fig. 1A). The initiator caspases are activated in the multiple-protein complex where they interact with their regulatory adaptor proteins through the DED or CARD domain. The initiator caspases further activate the downstream effector caspases through the cleavage at specific Asp residues. Once activated, the effector caspases cleave a broad spectrum of protein substrates, thereby inducing apoptosis or other biological functions.

\subsubsection{Caspase activating complexes: DISC, apoptosome, PIDDosome, and} inflammasome-Four distinct caspase activating complexes are formed with the initiator caspases. These include death inducing signaling complex (DISC), which mediates caspase-8 activation; apoptosome, which activates caspase-9; PIDDosome, $(\mathrm{PIDD}=\mathrm{p} 53$ induced death domain protein) which activates caspase-2; and inflammasome, which activates caspase-1. Each of these protein complexes is induced by distinct signals and has specialized functions.

Formation of the DISC is initiated by the binding of extracellular death ligands, such as Fas ligand and TNF-a, to their cell-surface death receptors (Peter and Krammer, 2003). Upon activation, death receptors undergo multimerization and recruit Fas-associated death domain (FADD) and RIP1 through the death domain (DD). FADD in turn interacts with caspase-8 via the DED. The oligomerizaton of caspase- 8 in the DISC leads to its activation and cleavage of the downstream effector caspases. This cell surface receptor-mediated process of apoptois is called the 'extrinsic pathway' (Fig. 1A and B). Of note, in certain cell types, the extrinsic pathway can cross-talk to the mitochondria-mediated apoptotic pathway (the 'intrinsic pathway'). Active caspase-8 cleaves Bid, a BH3-only pro-apoptotic Bcl-2 family protein, thereby triggering the release of mitochondrial proteins and the formation of the apoptosome as described below (Li et al., 1998; Luo et al., 1998).

The apoptosome is a wheel-shaped protein complex, which contains apoptotic protease activating factor-1 (Apaf-1), cytochrome $c$ and caspase-9. It is initiated through the release of pro-apoptotic proteins from the mitochondria. The mitochondrial membrane integrity is regulated by the balance between pro-apoptotic and anti-apoptotic B cell lymphoma 2 (Bcl-2) family proteins. When the pro-apoptotic signal is activated over a certain threshold in response to intracellular and environmental stress, Bcl-2-associated X protein (Bax) channels are formed at the outer mitochondrial membrane, which leads to the release of cytochrome $c$ and second mitochondria-derived activator of caspases (Smac) [also known as direct inhibitor of apoptosis-binding protein with low pI (Diablo)]. Released cytochrome $c$ triggers the formation of the apoptosome in the presence of ATP, which mediates conformational change and activation of caspase-9 (Li et al., 1997). In addition, Smac enhances caspase activation through the neutralization of inhibitor of apoptosis (IAP) proteins (Du et al., 2000; Verhagen et al., 2000) (Fig. 1A and B).

The PIDDosome contains the $\mathrm{p} 53$-induced protein with a death domain (PIDD), RIPassociated Ich-1/Ced-3homologue protein with a death domain, and caspase-2 (Tinel and Tschopp, 2004). PIDD is a p53 target gene whose expression is induced by genotoxic stress (Lin et al., 2000). Increased PIDD expression leads to formation of the PIDDosome, which mediates caspase- 2 activation. Activated capase- 2 acts upstream of mitochondrial intrinsic 
pathway, by inducing the cleavage of $\mathrm{BH} 3$ interacting domain death agonist (Bid) or directly causing cytochrome $c$.

The inflammasome is a pro-inflammatory complex composed of apoptosis-associated specklike protein containing a CARD (ASC), nucleotide-binding oligomerization domaincontaining protein (NOD)-like receptor (NLR) family or pyrin and HIN domain (PYHIN) family, and caspase-1. Several NLRs such as NLRP1, NLRP3 and NLRC4 and PYHIN family proteins such as absent in melanoma 2 (AIM2) assemble into the inflammasomes. The formation of the inflammasome is triggered by diverse danger signals including bacterial toxins, extracellular ATP and amyloid- $\beta$ fibrils, mitochondrial reactive oxygen species (ROS), double-stranded DNA (dsDNA) and others. Activation of caspase-1, which was initially called IL-1 $\beta$-converting enzyme, leads to the cleavage of pro-IL- $1 \beta$ and proIL-18 into their mature pro-inflammatory forms (Fig. 1A and C).

These molecular platforms for caspase signaling clearly indicate that caspases control not only apoptosis but also inflammation. In addition, recent studies have demonstrated unexpected physiological and pathological functions of caspases in the CNS (Hyman and Yuan, 2012). For example, localized caspase activation in neurons mediates the dendrite pruning and controls the synaptic formation and plasticity in the brain (Huesmann and Clayton, 2006; Kuo et al., 2006; Li et al., 2010b). In another case, caspase activation does not cause immediate cell death but induces neurofibrillary tangle formation in a mouse model of Alzheimer disease (de Calignon et al., 2010). The roles and mechanisms of these localized, low-level caspase activation in the retina have not been fully explored and require to be elucidated in future studies.

\subsection{Caspase inhibitors and clinical trials}

Caspase activation is regulated by several inhibitors: those derived from virus genes, those produced endogenously in cells, and chemically synthesized inhibitors (Callus and Vaux, 2007). The first caspase inhibitor discovered was cytokine response modifier A (CrmA), a cowpox virus-encoding protein. $\mathrm{Crm}-\mathrm{A}$ inhibits caspase-1-dependent cytokine maturation as well as caspase- 8 activity, thereby allowing viruses to evade elimination by the host's immune responses or apoptosis of infected cells. P35 and IAP are baculoviral gene products that prevent apoptosis during infection (Clem et al., 1991; Crook et al., 1993). While p35 directly inhibits caspases, baculoviral-derived IAP (OpIAP) acts upstream to prevent caspase activation. Viral FLICE-inhibitory proteins (v-FLIPs) were identified from the screening of $\gamma$-herpesvirus genes that share homology with caspase-8 (also called FLICE) (Thome et al., 1997). v-FLIP inhibits caspase- 8 activation induced by death receptors, and facilitates the persistence and replication of viruses in infected cells.

Mammalian cells are equipped with endogenous mechanisms of caspase inhibition (Fulda and Vucic, 2012). There are multiple IAPs that possess baculoviral IAP repeat (BIR) domain in mammals (Fulda and Vucic, 2012). Among them, X chromosome-linked IAP (XIAP) is the best characterized mammalian IAP that directly binds and inhibits caspase- $3,-7$ and -9 (Huang et al., 2001; Riedl et al., 2001). Other IAPs such as cellular IAPs (cIAPs) indirectly regulate caspase activation through the interaction with Smac. Besides caspase regulation, cIAPs also mediate pro-survival NF- $\kappa \mathrm{B}$ signaling through its ubiquitin ligase activity in the c-terminal really interesting new gene (RING) domain. Cellular FLIPs (c-FLIPs) are expressed in three splice variants (Yu and Shi, 2008). The shorter forms (c-FLIP and cFLIP $_{R}$ ) are reminiscent of v-FLIPs, and strongly inhibit caspase- 8 activation. The longer form (c-FLIP ${ }_{\mathrm{L}}$ ) structurally resembles to caspase- 8 , but lacks an enzymatic activity in its Cterminal domain. c-FLIP $\mathrm{L}_{\mathrm{L}}$ expression is induced by pro-survival NF- $\mathrm{kB}$ and Akt activation, and when highly expressed, c-FLIP $\mathrm{L}_{\mathrm{L}}$ competes with caspase- 8 and prevents the dimeric activation of caspase-8 and apoptosis induction (Scaffidi et al., 1999). However, at 
physiological expression levels, c-FLIP $\mathrm{L}_{\mathrm{L}}$ appears to support the enzymatic activity of caspase- 8 in the heterodimer complex with caspase-8 (Micheau et al., 2002). Recent studies have shown that the c-FLIP $\mathrm{L}_{\mathrm{L}}$-caspase- 8 heterodimer has a restricted substrate repertoire and appears to be critical for non-apoptotic function of caspase- 8 such as cell survival and proliferation (van Raam and Salvesen, 2012).

A number of synthetic caspase inhibitors have been developed in the laboratory and industries as research tools as well as potential therapeutics. Most of these inhibitors target the catalytic sites of caspases, and are relatively specific to each or multiple caspases. However, it should be noted that they could have off-target effects, such that a pan-caspase inhibitor Z-VAD inhibits nonrelated cysteine proteases such as calpains and cathepsins (Schotte et al., 1999). For clinical use, non-peptide or peptide-mimetic caspase inhibitors have been developed by pharmaceutical companies. However, despite extensive efforts over decades, there are only a few clinical trials employing caspase inhibitors in human diseases. PF-03491390 (formally called IDN-6556) is an anti-apoptotic caspase inhibitor that has advanced into phase 2 clinical trials (Fischer and Schulze-Osthoff, 2005). PF-03491390 is an irreversible and broad-spectrum caspase inhibitor, and blocks the activities of caspase-1, $-2,-3,-6,-7,-8$, and -9 (Hoglen et al., 2004). Intravenous or oral administration of PF-03491390 was generally well tolerated in phase 1 and 2 studies (Baskin-Bey et al., 2007; Shiffman et al., 2010; Valentino et al., 2003). Oral administration of PF-03491390 reduced serum AST and ALT in a phase 2 study for patients with chronic hepatitis C virus (Shiffman et al., 2010). In another clinical trial conducted for patients undergoing liver transplantation, intravenous administration of PF-03491390 reduced a serum marker of liver cell apoptosis (Baskin-Bey et al., 2007). VX-740 (or pralnacasan), a specific inhibitor of caspase-1, was tested in a phase 2 study for patients with rheumatoid arthritis patients. Although it was reported that VX-740-treated patients exhibited dose-dependent tendency towards improvement in disease symptoms, the trial was stalled because high dose treatment caused liver fibrosis in toxicology study in dogs (Linton, 2005). To our knowledge, there is no caspase inhibitor that has been used for retinal or neurodegenerative disorders or that has reached phase 3 trials.

\subsection{Knockout animals for caspase families}

The phenotypes of caspase knockout mice were summarized in a recent review by $\mathrm{Li}$ and Yuan ( $\mathrm{Li}$ and Yuan, 2008). Mice deficient for caspase-1 gene (Casp1 ${ }^{-/}-$mice) are viable, but are defective in mature IL-1 $\beta$ production and resistant to LPS-induced septic shock (Kuida et al., 1995; Li et al., 1995). Casp $3^{-/-}$mice in a mixed 129/SvJ and C57BL/6 background die at 1-3 weeks of age, and exhibit neuronal cell hyperplasia and decreased apoptosis in the brain and retina. However, because Casp $^{-/-}$mice in C57BL/6 background are viable and developmentally normal, these phenotypes may be attributed to unknown modifier genes in the $129 / \mathrm{SvJ}$ background in combination with the absence of caspase-3 (Leonard et al., 2002). While $\operatorname{Casp} 7^{-1-}$ mice appear to show a normal phenotype, Casp $^{-/-}$Casp $^{-/-}$double knockout mice in the C57BL/6 background die immediately after birth with defects in cardiac development (Lakhani et al., 2006), suggesting that these two effector caspases have redundant functions. Mice deficient for initiator caspases responsible for the extrinsic or intrinsic pathway also exhibit a lethal phenotype. Casp $8^{-/-}$mice die prenatally with impaired heart muscle development and abnormal vasculature formation (Varfolomeev et al., 1998). Casp $9^{-/-}$mice die perinatally with exencephaly and decreased apoptosis in the brain (Kuida et al., 1998). These findings indicate the distinct and redundant functions of individual caspases and their involvement not only in apoptosis but also in cell proliferation and differentiation through direct or indirect mechanisms. 
Although these studies are critical to understand the in vivo functions of caspases during development, their roles in postmitotic cells including photoreceptor cells are still unclear. There are several reasons for this shortage of understanding. First, because most of knockout mice in one or two major Casp are prenatally or perinatally lethal, it is not possible to investigate the phenotype of these mice in adult. One potential approach to overcome this limitation is a tissue-specific and inducible control of caspase expression using the Cre/loxP recombination system. For instance, it was shown that hepatocyte-specifice deletion of Casp- 8 protects hepatocytes from Fas-induced caspase activation and apoptosis (Kang et al., 2004). Targeted deletion of a specific Casp in the postmitotic photoreceptors will provide critical evidence for its functions in retinal diseases, and such approaches need to be addressed in future studies. However, the results from conditional knockout studies require careful interpretation because Cre-mediated recombination is not $100 \%$ efficient, and overexpression of Cre itself can be toxic to mammalian cells including retinal cells (Thanos et al., 2012). In addition, because members of the caspase family share redundant functions and exhibit cross-talk, it is possible that the depletion of one Casp can be compensated by the function of other caspases. Therefore, there remain some hurdles in genetic knockout studies, and careful and extensive investigation (using a combination of biochemical, pharmacological and genetic experiments) will be necessary to better understand the roles of caspases in pathological cell death.

\subsection{The role of caspase-dependent apoptosis in photoreceptor cell death after RD}

Machemer and colleagues introduced experimental RD in the owl monkeys (Machemer and Norton, 1968), and the subsequent studies using animal models of RD have revealed the occurrence of multiple biological events such as gliosis, inflammatory responses, RPE proliferation, and photoreceptor cell loss in the detached retina (Anderson et al., 1981; Erickson et al., 1983; Lewis et al., 1994; Jablonski et al., 2000). The first clear demonstration of apoptosis as a major form of photoreceptor cell death after RD was made by Cook and colleagues in a cat model of RD (Cook et al., 1995), following the establishment of TUNEL assay (Gavrieli et al., 1992). They showed that photoreceptor cells in the detached retina exhibit strong TUNEL reactivity as well as pyknotic morpholorical changes. Moreover, they demonstrated that the photoreceptor cell death after RD occurs in an earlier period than previously recognized: TUNEL-positive cells are detected as early as 1 to 3 days after RD, followed by a decline in their number over the next few weeks. This early activation of apoptosis, which begins within 1 day and peaks at 2-3 days after RD, has been confirmed in other animal models of RD and in human retinal samples with rhegmatogenous RD (Arroyo et al., 2005; Hisatomi et al., 2001).

Activation of caspases in the apoptotic photoreceptor cells after RD was first demonstrated by Zacks and colleagues. The enzymatic activities of both initiator caspases (caspase- 8 and -9) and effector caspases (caspase-3 and -7) are substantially increased in the rat retinas after RD (Zacks et al., 2003; Zacks et al., 2004). In addition, the expression levels of death ligands/receptors such as TNF-a, Fas-L, and Fas, which activate the extrinsic pathway, are elevated before and together with photoreceptor cell death (Nakazawa et al., 2011; Nakazawa et al., 2006. Both TNF and Fas pathways are functional in RD because antagonists to each molecule impair caspase activation and ameliorate photoreceptor cell death (Besirli et al., 2010; Zacks et al., 2004). Paradoxically, however, caspase inhibition in rodent eyes by intravitreal injection of pan-caspase inhibitor Z-VAD fails to prevent photoreceptor cell death after RD (Hisatomi et al., 2001; Trichonas et al., 2010). One possible explanation for this observation is that caspases are not the sole mediator of photoreceptor cell death after RD, but rather that other death signals downstream of TNF/ Fas may cooperate with caspases to induce photoreceptor cell death. Another explanation is that the inhibitors do not sufficiently block caspases due to the short half-life and poor 
penetration in the eye. Yet, the latter possibility seems to be less likely because intravitreal injection of Z-VAD shows biological changes such as decreased apoptosis and increased necrosis in the retina after RD (Trichonas et al., 2010), as described later.

In another study in our laboratory, Hisatomi and colleagues investigated the role of the intrinsic pathway using forebrain overgrowth (fog) mutant mice. The Fog mutation was found in the Apaf- 1 gene and results in near-to-complete loss of Apaf-1 expression and defects in neural tube closure. Whereas Apaf- $1^{-1-}$ mice die perinatally with exencephaly (Cecconi et al., 1998), fog/fog mice survive into adulthood, serving a valuable model to assess the functions of the intrinsic pathway in mature tissues (Honarpour et al., 2001). Creation of RD in fog/fog mice revealed that the photoreceptor cell death after RD was partially (but not completely) suppressed in fog/fog mice compared with WT mice (Hisatomi et al., 2008). Although we cannot fully exclude the possibility that residual amounts of Apaf-1 might mediate photoreceptor cell death in fog/fog mice, it is more likely that molecular interactions between different pathways, including the extrinsic pathway and/or other caspase-independent pathways, may compensate for each other in the initiation and execution process of photoreceptor cell death after RD.

\subsection{The role of caspase-dependent apoptosis in photoreceptor cell death in other retinal degenerative diseases}

$\mathrm{RP}$ is a genetically heterogenous group of inherited retinal degenerations. Molecular genetic studies have identified mutations in more than 50 genes, most expressed exclusively in rod photoreceptor cells, which are associated with RP (Hartong et al., 2006). In animals, including drosophila, rodents, rabbits, cats and dogs, there are several different models of RP, which occur naturally or are produced by genetic manipulation (Chang et al., 2002). Although the phenotypes arising from these mutations are different, Chang and colleagues showed that the rod photoreceptor cells undergo a common mode of cell death, apoptosis in $r d l$ (caused by Phosphodiesterase 6 $\beta$ (Pde6 $\beta$ ) mutation), $r d s$ (caused by Peripherin mutation), and Rhodopsin mutant mice (Chang et al., 1993). Portera-Cailliau and colleagues also demonstrated the involvement of apoptosis of rod photoreceptor cells in these animals, and suggested that retinal degeneration may be slowed by interfering with the apoptotic mechanisms (Portera-Cailliau et al., 1994). Subsequently, several studies investigeted the roles of caspases in animal models of RP; however, the results are conflicting. Whereas some studies reported an increased activity of caspase- 3 and -8 in $r d l$ mice (Jomary et al. 2001), others showed that activation of caspases is not observed in rd1 mice (Doonan et al., 2003). Yoshizawa and colleagues reported that intraperitoneal injection of a caspase-3 inhibitor provides mild and transient protection in $r d l$ mice (Yoshizawa et al., 2002). In contrast, other groups demonstrated that photoreceptor cell loss still occurs in caspase-3deficient mice or after caspase inhibition by Z-VAD (Sanges et al., 2006; Zeiss et al., 2004). In $r d 5$ mice, which carry mutation in the Tubby gene, a caspase-3 inhibitor partially reduces the photoreceptor cell death (Bode et al., 2003).

Excessive exposure to light triggers apoptosis of photoreceptor cells (Reme et al., 1998). Light-induced photoreceptor damage is initiated by overactivation of phototransduction pathway, because photoreceptor cells are rescued in the absence of 11-cis retinal, the chromophore of rod and cone opsins (Grimm et al., 2000; Sieving et al., 2001). Light appears to be an importnat cofactor in various retinal degenerative diseases. In animal models of RP, retinal degeneration is accelerated by light and conversely, is delayed by dark-rearing (Naash et al., 1996; Tam et al., 2007). In addition, light absorption by various chromophores within lipofuscin granules may mediate toxic effects on RPE cells in AMD (de Jong, 2006). Using retinal light injury model, several groups have investigated whether caspases play a role in the execution of photoreceptor cell death. Donovan and Cotter 
reported that photoreceptor apoptosis after light exposure is not inhibited by Z-VAD (Donovan and Cotter, 2002), while another group exhibited that it is partially attenuated by Z-VAD in a different setting of light level and inhibitor dose (Perche et al., 2007). Taken together, these findings suggest that, although caspases can be activated during retinal degeneration, they may not be the sole mediator of photoreceptor cell death. Althougth there is extensive literature investigating the roles of visual pigments, signal transduction moleculecules, and neurotrophic factors in RP and light injury, a detailed discussion regarding these mechanisms is beyond the scope of this article and can be found in previous reviews (Wenzel et al., 2005; Wright et al., 2010).

Two recent studies have shown that the NLRP3 inflammasome contributes to the progression of AMD. Tarallo and colleagues demonstrated that the NLRP3 inflammasome is activated in the RPE by $A l u$ RNA, repetitive element transcripts of non-coding RNA. Alu RNA accumulates in the RPE of patients with dry AMD, and overexpression of Alu RNA induces RPE cell death in vitro and in vivo (Kaneko et al., 2011). This Alu RNA toxicity is mediated via IL-18 maturation and is reversed by Nlrp3 deficiency (Tarallo et al., 2012), suggesting the detrimental role of the inflammasome during Alu RNA-induced retinal degeneration. In a separate study, Doyle and colleagues showed that drusen isolated from AMD patient eyes activate the inflammasome in macrophages, which in turn mediates caspase- 1 cleavage and the secretion of IL1- $\beta$ and IL-18. In addition, caspase- 1 cleavage is associated with the activated macrophages in a mouse model of AMD immunized with a oxidation fragment of docosahexaenoic acid (Hollyfield et al., 2008). Laser-induced CNV is more severe in Nlrp3-deficient mice, suggesting the protective role of the inflammasome against neovascularization (Doyle et al., 2012). Therefore, the inflammasome may have different functions depending on the site of activation (macrophage vs. RPE). Furthermore, the protective effect of IL-18 against CNV seems to contradict the previous report showing the anigiogenic effect of IL-18 in retinal neovascularization in a model of oxygen-induced retinopathy (Qiao et al., 2007). These discrepancies may result from the differences in underlying pathology (inflammation vs. hypoxia), and need to be addressed in future studies.

\subsection{Endogenous anti-apoptotic factors in the retina}

There are several endogenous survival mechanisms that counteract the apoptotic caspase cascade in the retina. First, it has been shown that caspase-dependent apoptosis is downregulated in post-mitotic neurons in the brain and retina because of a maturation-associated reduction in Apaf-1 and caspase-3 expression and increased efficacy of IAPs (Donovan and Cotter, 2002; Wright et al., 2004; Yakovlev et al., 2001).

Second, a number of pro-survival molecules are rapidly increased and/or activated during retinal degeneration. These include Jak-STAT, Akt, endothelin, and other pathways (Rattner and Nathans, 2005; Zacks et al., 2006). In an animal model of RP, Joly and colleagues reported that leukemia inhibitory factor (LIF), which mediates STAT3 activation, is upregulated in degenerating retina and supports photoreceptor cell survival (Joly et al., 2008). Consistent with these reports, rod photoreceptor-specific knockout of $g p$ 130, a common receptor for the IL-6 family of cytokines including LIF, increases photoreceptor cell death in models of RP and light injury (Ueki et al., 2009). In experimental RD, Chong and colleagues demonstrated that IL-6, an activator of Jak-STAT pathway, acts as a photoreceptor neuroprotectant, suggesting that Jak-STAT pathway may be a general endogenous protective mechanism against photoreceptor cell damage (Chong et al., 2008).

In addition, heat shock proteins (HSPs) are induced in the retina in response to various enviromenal stress. HSPs are cytoprotective molecular chaperones that prevent protein misfolding and aggregation. They also prevent the induction of apoptosis via directly interacting with pro- and anti-apoptotic molecules. In experimental RD, Kayama and 
colleagues showed that heat shock protein 70 (HSP70) is up-regulated in photoreceptors after RD and suppresses photoreceptor cell death via activating anti-apoptotic Akt and preventing caspase activation (Kayama et al., 2011). The crystallins, which belong to small HSP subfamily, are expressed not only in the lens but also the retina and brain (Andley, 2007). The levels of crystallins increase in various retinal disorders such as retinitis pigmentosa and AMD (Jones et al., 1998; Nakata et al., 2005). Although precise function of a-crystallins in these diseases has not been fully elucidated, Yaung and colleagues showed that hypoxia-induced retinal degeneration is exacerbated by $a A$-crystallin or $a B$-crystallin deficiency (Yaung et al., 2008). In addition, oxidative stress-induced cell death is attenuated by oxerexpression of aA-crystallin or aB-crystallin in RPE cell line (Yaung et al., 2007), suggesting the cytoprotective effect of a-crystallin in retinal degeneration.

Taken together, these findings suggest that increasing the efficacy of these endogenous protective mechanisms that counteract caspases and other pathways may be a potential strategy to prolong photoreceptor survival in RD and other retinal degenerative disorders.

\section{AIF-mediated mitochondrial pathway}

\subsection{AIF as a caspase-independent inducer of cell death}

AIF was discovered as the first protein that mediates caspase-independent apoptosis (Susin et al., 1999). AIF is a flavoprotein that is located in the mitochondrial intermembrane space (IMS) and involved in energy and redox metabolism (Modjtahedi et al., 2006). AIF modulates the structure and function of complex I of the respiratory chain, and thus is crucial for mitochondrial oxidative phosphorylation and cell survival (Vahsen et al., 2004). In contrast, under stress conditions, AIF is cleaved, translocates into the cytoplasm and the nucleus, and mediates chromatinolysis in a caspase-independent manner (Fig. 2A and B). In addition, recent studies have shown that AIF also promotes necrotic cell death in response to DNA alkylating agents (Artus et al., 2010; Moubarak et al., 2007).

AIF contains a transmembrane segment and is anchored to the inner membrane of the mitochondria. The mitochondrial release of AIF requires two-step process: mitochondrial outer membrane permeabilization (MOMP) and cleavage in the IMS (Otera et al., 2005). The cleavage of AIF is regulated by multiple molecules and signals. First, calpain I ( $\mu$ calpain), a calcium-dependent cysteine protease, is a critical enzyme to mediate AIF processing (Polster et al., 2005). Second, poly(ADP-ribose) (PAR) polymer, a product of PAR polymerase-1 (PARP-1) activation, has been shown to act as a potent AIF-releasing factor (Yu et al., 2002; Yu et al., 2006b). Third, reactive oxygen species (ROS) may modulate AIF cleavage through conformational changes (Churbanova and Sevrioukova, 2008). It was shown that oxidative modification sensitizes AIF to calpain-mediated processing (Norberg et al., 2010).

There is another step of regulation in the process of AIF translocation from the cytoplasm to the nucleus. Interaction of AIF and cyclophilin A is required for AIF nuclear translocation (Cande et al., 2004; Zhu et al., 2007). On the other hand, the inducible HSP70 under stress conditions binds to AIF and prevents its nuclear translocation (Ravagnan et al., 2001).

\subsection{AIF knockout or mutant animals}

Aif gene is located on the $\mathrm{X}$ chromosome, and Joza and colleagues demonstrated that Aifdeficient male ES cells ( Aif $^{-} / \mathrm{Y}$ ES cells) fails to produce chimeric mice after injection into host blastocysts. Aif deficiency abolishes the first wave of developmental cell death during cavitation of embryoid bodies, which is indispensable for development of the chimeric embryos (Joza et al., 2001). However, there is a controversial study using conditional Aif knockout mice. Brown and colleagues showed that loss of Aif function does not influence 
the cavitation process in embryoid bodies, but rather causes extensive cell death beginning at embryonic day 9, which results in impaired embryo growth. This seems to be attributed to reduced mitochondrial complex I activity in Aif-deficient embryos (Brown et al., 2006). Consistent with this report, skeletal muscle- or cardiac-specific Aif knockout mice exhibit impaired activity of complex I and develop progressive skeletal muscle atrophy or dilated cardiomyopathy (Joza et al., 2005). Targeted deletion of Aif in photoreceptor cells will be important to better understanding the roles of AIF in retinal development and degeneration.

The X-linked Harlequin $(\mathrm{Hq})$ mutation was originally identified in mice that exhibit a lack of hair, reduction in body weight, and ataxia in hemizygous males and homozygous females. Histology of $\mathrm{Hq}$ mice demonstrates a late onset degeneration of cerebellar neurons and retinal ganglion cells beginning after 3 months of age. It has been now shown that $\mathrm{Hq}$ mutation is a proviral insertion in the Aif gene, which causes about an $80 \%$ reduction in AIF expression (Klein et al., 2002). These findings further confirm that AIF is crucial for cell survival, especially in specific types of neurons including retinal ganglion cells. In addition, because $\mathrm{Hq}$ mice grow into adulthood, they represent an important model for studying the role of AIF in adult cells and organs.

Cells derived from Aif knockout or $\mathrm{Hq}$ mice show different responses to death stimuli compared with control wild-type cells. For instance, Aif ${ }^{-}$/Y ES cells are resistant to serum deprivation, but are equally susceptible to other cell death stimuli such as staurosporine, etoposide and ultraviolet irradiation (Joza et al., 2001). Primary granule cells from $\mathrm{Hq}$ mice undergo significantly less cell death after serum deprivation, while they are more susceptible to hydrogen peroxide or glutamate (Klein et al., 2002). Cortical neurons from $\mathrm{Hq}$ mice are resistant to PARP-1-mediated cell death induced by NMDA or PAR polymer (Xu et al., 2006). These results suggest that AIF is critical in mediating cell death in specific conditions (e.g., starvation) and certain cell types (e.g., neurons). Indeed, neuronal and retinal cell death in starved conditions substantially suppressed in $H q$ mice in vivo (Culmsee et al., 2005;

Hisatomi et al., 2008). However, because AIF has dual roles in cell survival and death, it is still difficult to address the precise pro-death function of AIF in these experiments. The loss of mitochondrial pro-survival function of AIF may alter the cellular physiological condition, which could influence the cell fate in response to death stimuli (Cheung et al., 2006).

\subsection{The role of AIF in photoreceptor cell death after RD}

Photoreceptors are highly polarized cells that consist of the light-sensitive outer segment, the mitochondrion-rich inner segment, the nuclear layer, and the synaptic terminal. This layered structure of photoreceptors provides an advantage to observe the molecular shuttling between the nucleus and mitochondria. Hisatomi and colleagues showed that AIF is located in the inner segment of photoreceptors in normal conditions. In contrast, AIF is observed in the shrunken nuclei of photoreceptors in the retina after RD (Hisatomi et al., 2001). To our knowledge, this is the first clear demonstration of AIF nuclear translocation during cell death in vivo. The authors further investigated the role of AIF in photoreceptor cell death after RD using $H q$ mice. In this study, experimental RD was induced in 8-week-old $H q / \mathrm{Y}$ mice, in which late-onset retinal degeneration had not been present. The results showed that the photoreceptor cell death after RD is partially suppressed in $H q$ mice compared with that in age-matched controls, suggesting that AIF contributes to RD-induced photoreceptor degeneration at least in part. Importantly, the human retina after RD shows AIF nuclear translocation as well as caspase activation in dying photoreceptor cells, as seen in rodent models of RD (Hisatomi et al., 2008). Collectively, these data suggest that not only caspases but also caspase-independent pathways are involved in photoreceptor cell death after RD.

Prog Retin Eye Res. Author manuscript; available in PMC 2014 November 01. 


\subsection{The role of AIF in photoreceptor cell death in other retinal degenerative diseases}

AIF has been implicated in other models of retinal degeneration. Nuclear translocation of AIF is observed in dying rod photoreceptor cells in mouse and rat models of RP (Sanges et al., 2006; Murakami et al., 2008). The retinas from RP animals exhibit increased activities of calpain and PARP, which mediate the mitochondrial release of AIF (Paquet-Durand et al., 2007; Sanges et al., 2006). Inhibition of calpain or PARP pathway prevents the nuclear translocation of AIF and attenuates rod photoreceptor cell death in RP models (Mizukoshi et al., 2010; Murakami et al., 2012a; Ozaki et al., 2012). These findings suggest that AIF translocation and its regulatory pathways mediate retinal degeneration in RP.

\section{RIP kinase and necrosis}

\subsection{RIP kinase signaling}

Two members of the RIP kinase family proteins, RIP1 and RIP3, have been identified as critical mediators of necrosis (Vandenabeele et al., 2010). RIP1 was originally identified as a protein that interacts with Fas (Stanger et al., 1995). RIP1 consists of an N-terminal serine/ threonine kinase domain, an intermediate domain, a RIP homotypic interaction motif (RHIM), and a C-terminal DD. RIP1 acts as a multifunctional adaptor protein downstream of death receptors, and mediates pro-survival NF- $\mathrm{kB}$ activation, caspase-dependent apoptosis, and RIP kinase-dependent necrosis (Festjens et al., 2007). RIP3 was found as a serine/threonine kinase that shares homology with RIP1 but does not possess a DD (Sun et al., 1999) (Fig. 3A). RIP3 contains the RHIM domain in its C-terminus, and directly binds to and phosphorylates RIP1 (Sun et al., 2002). Although the precise biological function of RIP1-RIP3 interaction was unclear for a long period, recent studies have revealed that RIP3dependent phosphorylation of RIP1 kinase in the RIP1-RIP3 complex is critical for the induction of death receptor-induced necrosis (Cho et al., 2009; He et al., 2009; Zhang et al., 2009a). This necrosis-inducing protein complex is termed the 'necrosome.'

5.1.1. RIP1 polyubiquitination and pro-survival NF-kB activation-In response to TNF-a stimulation, RIP1 is recruited to TNFR and forms a membrane associated complex with TNF receptor-associate death domain (TRADD), TNF receptor-associated factor 2 or 5 (TRAF2/5) and cIAP1/2, the so-called complex I (Micheau and Tschopp, 2003). cIAP1/2 are key ubiquitin ligases that induce RIP1 polyubiquitination in the complex I (Mahoney et al., 2008). This ubiquitin chain provides an assembly site for transforming growth factor- $\beta$ activated kinase-1 (TAK1), TAK1 binding protein 2 or 3 (TAB2/3) and inhibitor $\kappa \mathrm{B}$ kinase (IKK) complex, and mediates NF- $\kappa$ B activation (Ea et al., 2006). TNF-a-induced RIP1

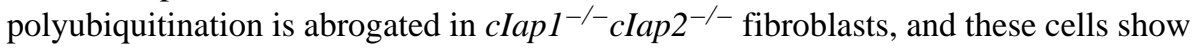
blunted NF- $\kappa \mathrm{B}$ activation and increased cell death, indicating that RIP1 polyubiquitination is critical for prosurvival NF- $\kappa B$ activation in TNF signaling (Varfolomeev et al., 2008). On activation, NF- $\kappa B$ translocates to the nucleus and induces transcription of prosurvival genes such as c-IAPs, c-FLIPs and IL-6 (Micheau et al., 2001; Wang et al., 1998). In addition, it mediates the induction of cylindromatosis (CYLD) or A20 (Jono et al., 2004; Krikos et al., 1992), which dephosphorylates RIP1 and acts as a negative feedback loop in NF- $\kappa B$ signaling (Trompouki et al., 2003; Wertz et al., 2004) (Fig. 3A and B).

\subsubsection{RIP1 deubiquitination and formation of cytosolic pro-death complex:} DISC or necrosome-In TNF signaling, RIP1 switches its function to a regulator of cell death when it is deubiquitinated by CYLD or A20 (Shembade et al., 2010; Wright et al., 2007). Deubiquitination of RIP1 abolishes its ability to activate NF- $\kappa B$ and leads to the formation of cytosolic pro-death complexes, the so-called complex II (Micheau and Tschopp, 2003). These complexes contain TRADD, FADD, RIP1, caspase-8, c-FLIP, and/or RIP3, and mediates either apoptosis or necrosis depending on cellular conditions.

Prog Retin Eye Res. Author manuscript; available in PMC 2014 November 01. 
Dimerization of caspase-8 in the DISC mediates a conformational change to its active form, thereby inducing apoptosis (Fig. 3A and C). On the other hand, in conditions where caspases are inhibited or cannot be activated efficiently, RIP1 interacts with RIP3 and forms the necrosome (Fig. 3A and D). RIP3-dependent activation of RIP kinase is crucial for necrosis induction in response to TNF-a (Cho et al., 2009; He et al., 2009; Zhang et al., 2009a). Other death ligands such as Fas-L are also capable to mediate RIP kinase-dependent necrosis as well as caspase-dependent apoptosis. In contrast to TNF-a, Fas directly recruits RIP1 and FADD to the plasma membrane, and forms pro-death complexes with caspase-8 and/or RIP3 (Stanger et al., 1995; Morgan et al., 2009). In 1998, Vercammen and others demonstrated two different pathways in Fas signaling: one rapidly leading to apoptosis, and a second directing the cells to necrosis if apoptosis is blocked by the caspase inhibitors (Vercammen et al., 1998b). The latter is now known to be mediated by RIP kinase activity (Holler et al., 2000; Cho et al., 2009).

In addition to death receptor signaling, RIP1 and RIP3 are involved in toll-like receptor (TLR) 3 and 4 signaling, which mediates innate immune response and cell death after infection and tissue injury. Double-stranded RNA (dsRNA) and lipopolysaccharide (LPS) are respective ligands for TLR3 and TLR4, and the activation of TLR3/4 triggers the recruitment of TIR-domain-containing adaptor inducing interferon- $\beta$ (TRIF), which further interacts with RIP1 and RIP3 through the RHIM domain. TLR3/4-induced NF- $\kappa$ B activation and cytokine production are mediated by RIP1 ubiquitination (Meylan et al., 2004; CussonHermance et al., 2005; Chang et al., 2009). In contrast, RIP3 is critical for RIP kinase activation and necrotic cell death induced by TLR3/4 in the presence of caspase inhibitor (He et al., 2011). Therefore, although different molecules are assembled through activation of death receptors and TLRs, RIP kinase may act as a common intermediary for various upstream signals.

5.1.3. Regulatory mechanisms of RIP kinase activation-Beause caspase inhibition sensitizes cells to RIP kinase-dependent necrosis, caspases may directly or indirectly inhibit RIP kinase activity. Indeed, caspase-8 directly cleaves and inactivates RIP1 and RIP3 (Feng et al., 2007; Lin et al., 1999). Interestingly, this inactivation does not require pro-apoptotic caspase- 8 activation through its homodimerization, but is mediated by the restricted caspase-8 activity in the heterodimer with c-FLIP (Oberst et al., 2011) (Fig. 3C and D). Knockdown of either caspase-8 or c-FLIP enhances the formation of the RIP1-RIP3 complex, suggesting that the caspase-8-c-FLIP heterodimer antagonizes RIP kinase activation without inducing apoptosis. In addition to its direct effect on RIP1/RIP3, caspase-8 prevents the necrosome formation through the cleavage of CYLD, which mediates RIP1 deubiquitination (O'Donnell et al., 2011).

While IAP antagonists promote apoptosis by increasing caspase activiy, they also facilitate the cells to undergo RIP kinase-dependent necrosis in certain conditions. It has been shown that loss of cIAP $1 / 2$ induces the spontaneous formation of a protein complex containing FADD, RIP1, caspase-8 and c-FLIP (Feoktistova et al., 2011; Tenev et al., 2011). TLR3 ligation in the absence of cIAP1/2 recruits TRIF to this complex and induces pro-apoptotic caspase activation. On the other hand, under conditions of caspase blockade, TLR3 stimulation with IAP antagonists causes necrotic cell death through RIP kinase activation (Feoktistova et al., 2011). IAP antagonists also enhance necrotic response in combination with TNF-a and/or Z-VAD (He et al., 2009; Vanlangenakker et al., 2010). Therefore, cIAP $1 / 2$ negatively regulates the formation of pro-death protein complex, which is necessary for cell death execution. Caspase activity in this complex appear to control if the cell death occur through caspases-dependent apoptosis or RIP kinase-dependent necrosis. 
The expression levels of RIP3 are another factor that control RIP kinase activation. Whereas RIP1 is expressed ubiquitously in all cell types, RIP3 expression differs amongst cells and tissue (Sun et al., 1999; He et al., 2009). In addition, the levels of RIP3 correlate with the responsiveness to necrotic cell death induced by TNF-a (He et al., 2009). The levels of caspases also change depending on cellular types and conditions. Caspase-dependent apoptosis is downregulated in the mature neurons because of reduced caspase-3 expression after development (Donovan and Cotter, 2002). Caspase-8 expression is substantially lower in RPE cells compared with other ocular epithelial cells or tumor cells, which may protect the RPE from apoptosis (Yang et al., 2007). Therefore, it is likely that the balance between caspases and RIP3 may be important to decide the cell fate (i.e., apoptosis or necrosis) in response to death receptor stimulation or other signals.

\subsubsection{Downstream signaling of RIP kinase leading to necrosis-Although the} downstream mechanisms by which RIP kinase causes necrosis are less unclear, recent studies have shown some downstream substrates responsible for the induction of necrosis. Mixed lineage kinase domain-like (MLKL) interacts with and is phosphorylated by RIP3 during necrosis initiation. Knockdown or inhibition of MLKL inhibits RIP kinase-dependent necrosis, but does not affect RIP1-RIP3 interaction, indicating that MLKL is a downstream target of RIP3 (Sun et al., 2012). Phosphoglycerate mutase 5 (PGAM5), a mitochondrial phosphatase located in the mitochondrial outer membrane, is another substrate of RIP kinase. In HeLa cells overexpressing RIP3, activated RIP3 translocates to the mitochondrial membrane and interacts with PGAM5 and the mitochondrial fission factor Drp1, thereby inducing the mitochondrial fragmentation. Knockdown of PGAM5 prevents the mitochondrial fission and attenuates RIP kinase-dependent necrosis (Wang et al., 2012), suggesting that RIP kinase may induce the mitochondrial necrotic pathway through the phosphatase activity of PGAM5. Another necrotic mechanism downstream of RIP3 may occur via the death domain-associated protein Daxx, which was recently identified as a novel substrate of RIP3 (Lee et al., 2013). This protein exerts opposite effects on ischemic cell death depending on its subcellular localization: when confined to the nucleus, Daxx protects against cell death, whereas nuclear export to the cytoplasm promotes JNK-mediated cell death (Jung et al., 2007). Lee and colleagues demonstrated that under oxygen glucose deprivation, RIP3 phosphoylates Daxx at Ser-668, resulting in nuclear export of Daxx and ischemic necrosis of rat retinal ganglion cells (Lee et al., 2013).

Previous works in the 1990s reported that overproduction of ROS occurs in death receptormediated necrosis (Goossens et al., 1995; Vercammen et al., 1998b). Consistent with these findings, recent studies have revealed the molecular links between RIP kinases and ROSregulating enzymes. First, activated RIP3 interacts with metabolic enzymes such as glycogen phosphorylase (PYGL), glutamate-ammonia ligase (GLUL) and glutamate dehydrogenase 1 (GLUD1). PYGL catalyzes the degradation of glycogen to glucose-1phosphate. GLUL and GLUD1 mediate glutaminolysis. GLUL catalyzes the synthesis of glutamine from glutamate and ammonia, and GLUD1 is a mitochondria matrix enzyme that converts glutamine to a-ketoglutarate. Activation of these enzymes eventually stimulates the Krebs cycle and oxidative phosphorylation, thereby increasing mitochondrial ROS production (Zhang et al., 2009a). Secondly, after TNF-a stimulation, RIP1 forms a complex with TNFR, riboflavin kinase, and NADPH oxidase 1. NADPH oxidase is the bestcharacterized non-mitochondrial source of ROS and forms a membrane-bound enzyme complex with $\mathrm{p} 22^{\text {phox }}$ and Rac (Sumimoto, 2008). This complex generates superoxide by transferring an electron from NADPH in the cytsol to oxygen on the luminal side or in the extracellular space (Kim et al., 2007; Yazdanpanah et al., 2009). Thirdly, RIP1 kinase activates autophagic degradation of catalase, which converts hydrogen peroxide to water and oxygen, thereby increasing ROS accumulation (Yu et al., 2006a). The requirement of ROS for RIP kinase-mediated necrosis has been demonstrated in several (albeit not all) types of 
cells (Vanlangenakker et al., 2010), suggesting the importance of ROS as a downstream target in RIP kinase signaling at least in certain conditions.

Although RIP1 is a key substrate of RIP3 in the induction of necrosis, it should be noted that, in some instances, RIP3 mediates necrosis in RIP1-independent manner. Upton and others showed that mouse cytomegalovirus infection induces RIP3-dependent cell death in 3T3 fibroblasts, which cannot be inhibited by Nec-1 or RNAi knockdown of RIP1 (Upton et al., 2010). Therefore, it is likely that RIP3 may have additional substrates besides RIP1 during necrosis induction. Further studies investigating the currently unknown substrates of RIP3 will be important for the better understanding of RIP kinase signaling.

5.1.5. Non-necrotic role of RIP kinase-It was shown that RIP kinase is not essential for $N F-\kappa B$ activation and pro-inflammatory cytokine production induced by death receptor and TLR ligands (Newton et al., 2004). However, recent studies have suggested that RIP kinase not only regulate necrosis, but also has a role in mediating inflammatory response. Biton and Ashkenazi showed that extensive DNA damage induces TNF-a production and further activates RIP kinase in an autocrine feedforward signaling loop in Hela cells. In turn, RIP kinase triggers JNK3-dependent IL-8 production (Biton and Ashkenazi, 2011). Vince and colleagues showed that TLR priming with IAP antagonists mediate inflammasome activation and IL1- $\beta$ production in a RIP kinase-dependent manner in macrophages (Vince et al., 2012). However, the role of RIP kinase in inflammasome activation has been controversial, because IL- $1 \beta$ maturation can be induced in a RIP3-independent manner in Fas-stimulated macrophages or in a mouse model of autoinflammatory disease (Bossaller et al., 2012; Lukens et al., 2013). Moreover, Christofferson and colleagues reported that caspase inhibition activates RIP kinase and another protein EDD, which in turn mediating JNK activation and Sp-1-dependent transcription of TNF-a in L929 cells (Christofferson et al., 2012). These finding suggest that RIP kinase may directly modulate inflammatory response in certain conditions. However, it should also be noted that inflammation can be induced subsequent to RIP kinase-dependent necrosis, since intracellular proteins released from necrotic cells can act inflammatory mediators (please see the details in the section '8.2. Inflammatory signals from dying or dead cells'). It has been shown that Rip3 deficiency ameliorates inflammation as well as necrosis in models of sepsis, colitis, and RD (Duprez et al., 2011; Welz et al., 2011; Trichonas et al., 2010). The precise mechanisms by which RIP kinase regulates inflammation warrant further investigation.

\subsection{RIP kinase inhibitors}

Degterev and colleagues identified small compounds named necrostatin that specifically inhibit death receptor-mediated necrosis in a cell-based screening of $\sim 15,000$ chemical compounds (Degterev et al., 2005). Necrostatin-1 (Nec-1) has been shown to strongly inhibit RIP1 kinase phosphorylation, and structure-activity relationship analysis demonstrated that Nec-1 may bind to the adaptive pocket on RIP1 and stabilize the inactive conformation of RIP1 kinase (Degterev et al., 2008). Nec-1 inhibits the formation of necrosome complex induced by TNF-a both in vitro and in vivo (Cho et al., 2009; He et al., 2009). Importantly, other two necrostatins, which have different structures than Nec-1, also inhibit RIP1 kinase phosphorylation, suggesting that necrostatins target RIP1 kinase.

However, there are some reports raising concerns about the specificity of necrostatins. For instances, it was shown that Nec-1 partially affects the PAK1 and PKAca activity on a panel screening of 98 human kinases (Biton and Ashkenazi, 2011). Cho and colleagues reported that Nec-1 exerts RIP1-dependent and independent effects for inhibition of necrosis (Cho et al., 2011). More recently, Takahashi and colleagues demonstrated critical issues on the specificity and activity of Nec-1. They report that Nec-1 is identical to methyl-

Prog Retin Eye Res. Author manuscript; available in PMC 2014 November 01. 
thiohydantoin-tryptophan (MTH-Trp), an inhibitor of indoleamine 2,3-dioxygenase (IDO) (Takahashi et al., 2012). IDO is the rate-limiting enzyme in tryptophan catabolism, and modulates immune tolerance. It was shown that IDO-dependent effect of immune suppression is inhibited by MTH-Trp/Nec-1 (Jurgens et al., 2009), suggesting the possibility that Nec-1 may modulate inflammatory reaction through targeting IDO.

Nec-1i is an inactive derivative of Nec-1, in which the methyl group in the thiohydantoin moiety is eliminated. Although Nec-1i shows only a minor inhibitory effect on human RIP1 kinase phosphorylation in a cell-free kinase assay, it inhibits necrotic cell death in mouse in vitro and in vivo systems, and is equipotent to Nec-1 at higher concentration. In addition, Nec1i also suppresses IDO activity (Takahashi et al., 2012). These findings exclude the use of Nec-1i as an inactive control, at least in mouse experiments. The authors showed that 7Cl-O-Nec-1, a more potent and stable derivative of Nec-1, selectively inhibits RIP1 phosphorylation without affecting IDO activity, suggesting it as a superior RIP1 kinase inhibitor (Degterev et al., 2013; Takahashi et al., 2012). However, because 7-Cl-O-Nec-1 is not currently commercially available, most data on pharmacological targeting of RIP1 have been obtained using Nec-1, especially in vivo experiments (Linkermann et al., 2012; Rosenbaum et al., 2010; You et al., 2008; Zhu et al., 2011). Hence, interpretation of these results requires consideration of its nonspecific effect, and additional experiments using RIP3-deficient mice or RNAi knockdown of RIP kinase will help the precise understanding of the role of RIP kinase in diseases.

\subsection{Knockout animals for RIP kinases}

Rip $^{-/-}$mice exhibit postnatal lethality with reduced NF- $\kappa \mathrm{B}$ activation and extensive cell death in lymphoid and adipose tissues. Ripl-deficient cells fail to activate NF- $\mathrm{BB}$ in response to TNF- $\alpha$ and are susceptible to TNF-a-induced cell death (Kelliher et al., 1998), suggesting that a reduction in prosurvival NF- $\kappa \mathrm{B}$ signals may cause lethality in ip $^{-/-}$ mice.

In contrast, $R i p 3^{-/-}$mice are viable and do not show gross abnormality in any of the major organs including the retina. Fibroblasts and macrophages derived from Rip $3^{-1-}$ mice exhibit comparable NF- $\kappa$ B activation in response to TNF-a (Newton et al., 2004). Although Rip $3^{-/-}$ mice are indistinguishable from WT mice in physiological conditions, recent studies have revealed that they display marked reduction in necrotic response against viral infection or in tissue injury. Vaccinia virus, which encodes the viral caspase inhibitor B13R/Spi2, was shown to sensitize the host cells to TNF-induced necrosis (Chan et al., 2003). Cho and colleagues demonstrated that RIP3 is essential for the induction of necrosis after vaccinia virus infection (Cho et al., 2009). Consequently, Rip $^{-/-}$mice fail to eliminate infected cells and control viral replication. Interestingly, murine cytomegalovirus encodes a viral RIP kinase inhibitor, which interacts with RIP1/3 via RHIM and counteracts necrosome formation (Upton et al., 2008, 2010). These findings suggest that certain viruses have strategy to evade elimination by inhibiting necrosis of the host cells. RIP3-dependent necrosis is also implicated in cerulein-induced pancreatic injury, ethanol-induce liver injury, atherosclerosis, and retinal degeneration after RD and in RP (He et al., 2009; Roychowdhury et al., 2012; Lin et al., 2013; Trichonas et al., 2010; Murakami et al., 2012b) (please see the detailed retinal phenotypes in next section).

Genetic ablation of $\mathrm{Casp}^{-/-}$results in embryonic lethality with impaired development of heart and vasculature (Varfolomeev et al., 1998). Because caspase-8 negatively regulates RIP kinase-dependent necrosis (Feng et al., 2007; Lin et al., 1999), two independent groups have tested the hypothesis that Casp 8 deficiency may activate RIP kinase pathway during embryonic development. Indeed, the embryonic lethality of $\operatorname{Casp}^{-/-}$mice is completely rescued by Rip 3 deficiency, indicating the crucial function of caspase- 8 in suppressing RIP 
kinase in vivo. Although Casp $8^{-/-}$Rip $3^{-/-}$mice display normal development and fertility, aged animals develop lymphoadenopathy, probably because of impaired induction of apoptosis and necrosis in lymphocytes (Kaiser et al., 2011; Oberst et al., 2011). The inhibitory function of caspase- 8 on RIP kinase is further confirmed by a recent study showing that target deletion of Casp 8 in intestinal epithelium induces RIP3-dependent necrosis and intestinal inflammation. They also showed that increased levels of RIP3 expression and the presence of necrosis in Paneth cells in patients with Crohn's disease, suggesting that RIP kinase may be also important in the pathology of human diseases (Gunther et al., 2011).

FADD and c-FLIP are components of the DISC and necrosome, and Fadd $^{-/-}$and c-Flip ${ }^{-/-}$ mice show embryonic lethality with cardiac failure and hemorrhage, which are reminiscent of the phenotype of $\mathrm{Casp}^{-/-}$mice (Yeh et al., 2000; Yeh et al., 1998). Fadd ${ }^{-/-}$embryos exhibit increased levels of RIP1, and Ripl deficiency restores normal embryogenesis of Fadd $^{-/-}$mice (Zhang et al., 2011), indicating that FADD inhibits RIP1-dependent cell death. This concept is further supported by other studies in which tissue-specific knockout of Fadd in keratinocytes or intestinal epithelial cells caused RIP3-dependent necrosis in skin or intestine (Bonnet et al., 2011; Zhang et al., 2011). Alternatively, He and colleagues showed that Flip-deficient T cells become susceptible to RIP1-dependent necrotic cell death in response to $\mathrm{T}$ cell receptor stimulation, suggesting that c-FLIP also inhibits RIP kinase activation (He and $\mathrm{He}, 2013)$. clap $^{-/-}$clap $^{-/-}$mice die prenatally associated with defects

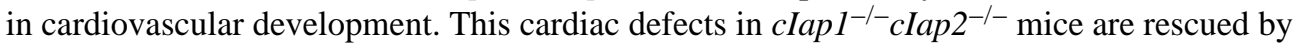
additional Rip1 or Rip 3 deficienty (Moulin et al., 2012), suggesting the ubiquitination of RIP1 by cIAPs may negatively regulate RIP kinase activation during development. Taken together, these in vivo data indicate that there are multiple molecules that regulate RIP kinase activation during development and in disease.

\subsection{The role of RIP kinase in photoreceptor cell death after RD}

Although apoptosis is a predominant form cell death after RD, previous morphological analysis described the presence of necrosis in RD-induced photoreceptor cell death (Erickson et al., 1983). However, necrosis was not considered as a therapeutic target for a long period because of the general concept that necrosis is an uncontrolled process of cell death. During photoreceptor cell death after RD, death ligands such as TNF-a and Fas-L (which mediate not only apoptosis but also necrosis) are up-regulated and contribute to photoreceptor cell loss (Besirli et al., 2010; Nakazawa et al., 2011; Zacks et al., 2007). However, caspase inhibition by the pan-caspase inhibitor Z-VAD is not sufficient to prevent photoreceptor cell loss after RD (Hisatomi et al., 2001). Given the emerging roles of RIP kinase-dependent necrosis especially in conditions where caspase pathway is inhibited, we hypothesized that RIP kinase may act as an alternative pathway of photoreceptor cell death after RD. Trichonas and colleagues demonstrated that, while RIP3 is barely detectable in the normal retina, its expression increases over 10-fold in the retina after RD (Trichonas et al., 2010). Induction of RIP3 also occurs during cerulein-induced pancreatitis, carotid artery injury, and liver steatohepatitis (Csak et al., 2011; He et al., 2009; Li et al., 2010a). Because the expression levels of RIP3 have been shown to correlate with necrotic responses in various cell lines (He et al., 2009), the increased RIP3 may sensitize cells to undergo necrosis in these pathological conditions. Furthermore, our morphological analysis using TEM showed that treatment with Z-VAD decreases apoptosis but substantially increases necrotic cell death of photoreceptors (Fig. 4A and B). Theses necrotic changes after caspase inhibition are rescued by additional Nec-1 treatment or Rip3 deficiency (Fig. 4C). These findings clearly demonstrate that RIP kinase-dependent necrosis is essential pathway for photoreceptor cell death after RD, which acts in concert with caspase-dependent apoptosis. 
Recently, an independent group has also detected the involvement of RIP kinase in photoreceptor cell loss after RD in a non-pigmented strain of rats. (Dong et al., 2012).

\subsection{The role of RIP kinase in photoreceptor cell death in other retinal degenerative diseases}

In RP, vision loss typically begins with loss of night vision because of rod dysfunction and death, followed by loss of daylight vision because of subsequent cone cell death. Rod photoreceptor cell death in RP has been shown to occur through apoptosis (Chang et al., 1993). In contrast, the mode of cone cell death has been less well characterized. In RP patient eyes with extensive rod degeneration, TEM studies demonstrated that the remaining cones had swollen cytoplasm, disruption of plasma membrane and autophagic vacuoles, suggesting that nonapoptotic mechnisms may be involved in the secondary death of cones. In our recent work, we investigated whether RIP kinase-dependent necrosis plays a role in photoreceptor cell death in $r d 10$ mice, which carry a missense mutation in the Pde $6 \beta$ gene. RIP3 expression increases in $r d 10$ mouse retinas in the phase of cone but not rod degeneration. Rd10 mice lacking Rip3 develop comparable rod degeneration to control $r d 10$ mice. In contrast, Rip 3 deficiency substantially rescues cones against cell death in $r d 10$ mice. Furthermore, TEM analysis showed that dying cones in $r d 10$ mice exhibit necrotic morphology, which is rescued by Rip3 deficiency (Murakami et al., 2012b). These findings suggest that necrotic mechanisms involving RIP kinase are crucial in cone cell death in RP and may be a potential therapeutic target. Further studies will be needed to clarify the roles of RIP kinase in other models of RP.

Chang and colleagues investigated the function of Fas in vitro model of light-induced cell death. They showed that treatment with Fas-L antagonist or the caspase- 8 inhibitor prevents light-induced apoptosis in $661 \mathrm{~W}$ photoreceptor-like cells. However, it simultaneously induces RIP kinase-dependent necrosis. Therefore, targeting both caspase and RIP kinase pathways is required for efficient protection of $661 \mathrm{~W}$ cells agains light-induced cell death (Chang et al., 2012). The roles of RIP kinase-depenent necrosis in vivo light injury model warrarnt further investigation.

In retinal ischemic-reperfusion injury model, Rosenbaum and colleagues showed that intravitreal injection of Nec-1 protects retinal inner neurons against cell loss and provides functional improvement. They also reported that $\mathrm{Nec}-1$ inhibits autophagy activation after retinal ischemic injury (Rosenbaum et al., 2010). In another study, Fujita and collegues investigated the function of prothymosin- $a$, which swiches the cell death mode from necrosis to neurotrophin-reversible apoptosis (Ueda et al., 2007), in retinal ischemicreperfusion injury. They showed that neurotrophins such as brain-derived neurotrophic factor and erythropoietin are upregulated in the ischemic retina, and treatment with prothymosin- $\alpha$ attenuates both apoptotic and necrotic cell death after ischemic injury (Fujita et al., 2009). These findings suggest that not only apoptotic but also necrotic mechanisms are involved in retinal degeneration, and that targeting necrotic pathways in combination with endogenous anti-apoptotic mechanisms may be a potential therapy for retinal degenerative diseases.

\section{Atg family and autophagy}

\subsection{Molecular machinery of autophagy}

Autophagy is the major catabolic mechanisms that involve degradation of cell's own components via lysosomal machinery (Mizushima et al., 2008). Upon induction of autophagy, a small vesicular sac called the 'isolation membrane' elongates and subsequently encloses a portion of cytoplasm, which results in the formation of a double-membraned 
autophagosome. Then, the outer membrane of the autophagosome fuses with a lysosome to form autolysosome, leading to the degradation of the enclosed materials (Fig. 5).

Since the identification of Atg genes that are essential for autophagy induction in yeast (Tsukada and Ohsumi, 1993), significant progress has been made in understanding the molecular machinery of autophagy. Over 30 Atg genes have been identified in yeast, many of which have mammalian homologues. In the induction of autophagy, Atg6 (also known as Beclin-1) forms class III phosphoinositide-3-kinase (PI3-kinase) complex with Atg14, vacuolar protein sorting (VPS)34, and p150/VPS15. Upon activation of class III PI3-kinase, Atg12-Atg5 conjugate and microtubule-associated protein LC3, a mammalian homologue of Atg8, are recruited to the isolation membrane, which sequesters cytoplasmic materials (Ohsumi, 2001). LC3 is synthesized as a cytoplasmic precursor, which is cleaved by the cysteine proteinase Atg 4 (belonging to the caspase family) and becomes LC3-I (Kirisako et al., 2000). LC3-I is subsequently conjugated with membrane-bound phosphatidylethanolamine (PE) to form LC3-II, which is essential for autophagosome completion (Ichimura et al., 2000). This LC3 conversion is mediated by ubiquitin ligase-like activity of Atg7 (E1-like) and Atg3 (E2-like). Following the formation of autophagosome, LC3-II is deconjugated by Atg4 and released from the membrane for recycling, or degraded by lysosomal enzymes in the autolysosomes (Fig. 5).

LC3 has been a useful marker for monitoring and quantifying autophagy (Mizushima et al., 2010). The conversion of LC3-I to LC3-II can be detected by Western blotting because LC3-II migrates faster than LC3-I in SDS-PAGE due to the hydrophobicity of LC3-II. Translocation of LC3 from the cytosol to the autophagosome membrane is visualized by the immunofluorescence or overexpression of LC3-GFP fusion protein. However, it should be noted that the number of LC3-II-positive autophagosomes does not always correlate with autophagic activity. The increase in autophagosomes may result from either the increased generation of autophagosomes and/or the reduced clearance of autophagosomes due to impaired fusion of autophagosomes and autolysosomes. Similarly, the increased levels of LC3-II expression represent either the increases in LC3 conversion and/or the decreased degradation of LC3-II in the autolysosomes (Tanida et al., 2005).

\subsection{The roles of autophagy in cellular homeostasis}

6.2.1. Cell death mediated by autophagy-Autophagic cell death is a form of cell death distinct from apoptosis and characterized primarily by the formation of numerous autophagic vacuoles (Schweichel and Merker, 1973). This extensive activation of autophagy in dying cells has led scientists to suggest that autophagy may play a major role in the destruction of the cells (Kroemer and Levine, 2008). Indeed, genetic and biochemical studies confirm that autophagy actively mediates cell death in certain conditions. For instance, $\mathrm{Yu}$ and colleagues showed that caspase inhibiton in L929 fibroblasts induces cell death associated with massive autophagy accumulation. Importantly, this autophagic cell death is reversed by the autophagy inhibitor or knockdown of Atg7 or Beclin-1 (Yu et al., 2004). In embryonic fibroblasts deficient for pro-apoptotic Bcl-2 family members Bax and Bcl-2 homologous antagonist killer ( $B a k$ ), photodamage induces autophagic cell death in a manner dependent on Atg5 and Beclin-1 (Buytaert et al., 2006). These results indicate excess autophagy can execute cell death, especially when cells are not able to undergo apoptosis. In addition, several studies have shown the link between autophagy and necrosis. Degterev and colleagues showed that autophagosome formation is induced downstream of RIP kinase activation in Jurkat cells. However, because 3-methyladenine (3-MA) treatment does not prevent death receptor-induced necrosis, autophagy may not actively contribute to cell death execution in this condition (Degterev et al., 2005). On the other hand, Bonapace and colleagues reported that combined treatment of glucocorticoids and obatoclax, an 
antagonist of pro-survival Bcl-2 family members, induces Atg protein- and RIP kinasedependent cell death, where Atg proteins act upstream of RIP kinase (Bonapace et al., 2010). These findings indicate that there are substantial cross-talks between apoptosis, autophagic cell death and necrosis, and elucidating the molecular links warrants further investigation.

6.2.2. Cytoprotective roles of autophagy-It has been hypothesised that autophagy is activated to counteract cellular stress and damage (Clarke, 1990). Recent accumulating evidence shows that autophagy is critical for maintaining cellular homeostasis, as supported by studies demonstrating increased cell death in cells lacking Atg 5 or Beclin-1 (Boya et al., 2005). Consistently, autophagy inhibition by Beclin-1 knockdown promotes sensitivity to metabolic stress in tumor cells, indicating the prosurvival role of autophagy to confer stress tolerance (Degenhardt et al., 2006). In addition, autophagy mediates the clearance and recycling of defective proteins and organelles (Williams et al., 2006). In culture models of Huntington disease, autophagy promotes the degradation of protein aggregates and prevents cell death induced by mutations in the HTT gene (Bjorkoy et al., 2005; Ravikumar et al., 2002). In a mouse model of Alzheimer disease induced by transgenic overexpression of amyloid precursor protein, Pickford and colleagues showed that heterozygous deficiency of Beclin-1 exacerbates amyloid- $\beta$ deposition and neurodegeneration (Pickford et al., 2008). These data suggest that autophagy mediates cell survival by eliminating mutant or defective proteins during neurodegeneration. Accumulation of amyloid- $\beta$ is also implicated in the pathogenesis of AMD (Johnson et al., 2002; Yoshida et al., 2005). Wang and colleaguse showed that autophagic markers are upregulated in the drusen of human AMD eyes or in stressed RPE cells (Wang et al., 2009). Further studies should address whether autophagy functions to counteract or promote the disease progression using in vitro and in vivo models of AMD.

\subsection{Autophagy inhibitors and inducers}

6.3.1. Autophagy inhibitors-As autophagosome formation requires class III PI3-kinase activity, one of the most commonly used pharmacological approaches to inhibit autophagy involves the use of PI3-kinase inhibitors such as wortmannin, LY294002, or 3-MA (Blommaart et al., 1997; Seglen and Gordon, 1982) (Fig. 5). However, these reagents can also inhibit class I PI3-kinase activity (Knight et al., 2006), and both PI3-kinases regulate not only autophagy but also a variety of cell signaling (e.g., membrane trafficking). Furthermore, 3-MA is used at very high concentrations to inhibit autophagy (millimolar range) so that it potentially affects other cellular processes (Caro et al., 1988). Another approach is to interrupt autophagy maturation by lysosomotropic reagents such as bafilomycin A1 or chloroquine (Fig. 5). These reagents block autophagy at a late stage by inhibiting fusion between autophagosomes and autolysomes or lysosomal acidification (Yamamoto et al., 1998; Suzuki et al., 2002). Inhibition of autophagy maturation results in an increase in LC3-II-positive autophagic vacuoles, representing a decreased turnover of autophagic vacuoles. Based on basic studies showing the pro-survival effect of autophagy in tumor cells (Katayama et al., 2007), chloroquine and its derivative hydroxychloroquine has been tested in clinical trials in multiple cancers as an adjuvant of chemotherapy (Mancias and Kimmelman, 2011; Townsend et al., 2012). In a phase III trial for glioblastoma patients, chloroquine showed a trend to improve mid-term survival when given in addition to conventional treatment of glioblastoma (Sotelo et al., 2006).

6.3.2. Autophagy inducers-In the upstream of autophagic flux, class III PI3-kinase is necessary for the formation of autophagosomes. Class III PI3-kinase is negatively regulated by mammalian target of rapamycine (mTOR). Therefore, inhibitors of mTOR such as rapamycin or Torin1 induce autophagy via the activation of class III PI3-kinase (Ravikumar

Prog Retin Eye Res. Author manuscript; available in PMC 2014 November 01. 
et al., 2006; Thoreen et al., 2009) (Fig. 5). Rapamycin exerts a broad range of therapeutic effect, including the ability to inhibit inflammation and proliferation, and has been approved as an oral medication to prevent rejection in organ transplantation. Rapamycin has been tested in clinical trials for treamtnent of AMD and diabetic retinopathy, and uveitis. Wong and collegues repoted that repeated subconjunctival rapamycin treatment was well-tolerated in patients with dry AMD; however, no positive anatomic or functional effects were indentified in their phase I/II trial (Wong et al., 2013). Lithium is also known to induce autophagy and enhance the clearance of mutant proteins. The autophagy-enhancing properties of lithium are not dependent on mTOR but mediated by decreasing myoinositol-1,4,5-triphosphate (IP3) (Sarkar et al., 2005). Lithium has been translated to clinical trial for the treatment of amyotrophic lateral sclerosis; however, this trial has been stalled because of the adverse events related to lithium (Sacca et al., 2013).

\subsection{Knockout animals for Atg families}

Systemic deletion of Atg genes essential for autophagic machinery resulted in neonatal

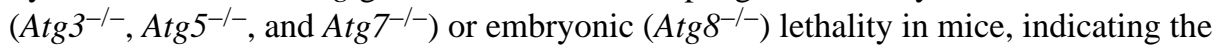
essential roles of autophagy in development and differentiation (Mizushima and Levine, 2010). Mice deficient for Atg $4 C$ which encodes autophagin-3 and is a most widely expressed Atg 4 homolog in mouse and human tissues, are viable, fertile, and develop normally. Atg $4 C^{-1-}$ mice show a decreased autophagic activity in the diaphragm muscle under starved conditions, indicating that $\mathrm{Atg} 4 \mathrm{C}$ is required for a proper autophagic response under stressed conditions (Marino et al., 2007). In contrast, mice deficient for Atg $4 B$ (autophagin1) exhibit defects in inner ear development (Marino et al., 2010). Atg4 ${ }^{-/-}$mice also show abnormal structure of deep cerebellar neurons, displaying mild impairment of motor performance (Read et al., 2011).

The roles of basal level of autophagy have been further investigated using conditional Atg knockout mice. Komatsu and colleagues demonstrated that liver-specific Atg7 deficiency leads to impaired autophagosome formation and hepatomegaly associated with hepatocyte swelling and accumulation of ubiquitin-positive protein aggregates (Komatsu et al., 2005). Hara and colleagues reported that Atg5 deficiency in CNS neurons induces accumulation of ubiquitin-positive inclusions in the brain and loss of neuronal cells such as Purkinje cells, accompanied by progressive deficits in motor function (Hara et al., 2006). Neuron-specific $\operatorname{Atg} 7$ knockout mice show more severe degeneration in the cerebral and cerebellar cortices, and die within 28 weeks of age (Komatsu et al., 2006). These data suggest that basal autophagy is critical for cell survival, probably through the clearance of ubiquitin-positive defective proteins in multiple organs.

\subsection{Research in autophagy and photoreceptor cell death}

Photoreceptor cell autophagy was first documented by Reme and colleagues in a series of TEM studies, and was considered to be an important degradative pathway of visual cycle proteins and organelles in normal condition (Reme, 1977; Reme and Young, 1977). They also showed that the number of autophagic vacuoles increases after light exposure in frog and rat photoreceptor cells (Reme and Knop, 1980; Reme et al., 1999). They speculated that autophagic degradation of visual pigments may protect photoreceptor cells against light damage by absorbing too many photons. In accordance with recent advances in the molecular understanding of autophagic machinery, scientists have addressed the role of autophagy in photoreceptor cell death after light injury. Kunchithapautham and colleagues showed that the levels of LC3-II are up-regulated in the mouse retina after light injury and $661 \mathrm{~W}$ photoreceptor-like cells treated with $\mathrm{H}_{2} \mathrm{O}_{2}$. Treatment with 3-MA or knockdown of Atg 5 or Beclin 1 partially blocks $661 \mathrm{~W}$ cell death induced by $\mathrm{H}_{2} \mathrm{O}_{2}$ (Kunchithapautham and Rohrer, 2007), suggesting the possibility that autophagy may contribute to oxidative stress- 
induced photoreceptor cell death. In contrast, a number of in vivo experiments have demonstrated the protective function of autophagy in light-induced retinal damage. Wang and colleagues showed that suppression of autophagy by genetic activation of mTOR sensitizes photoreceptor cells to age- and light-dependent degeneration in Drosophila (Wang et al., 2009). Consistently, Midorikawa and colleagues reported that knockdown of Atg-7 or Atg- 8 causes a similar phenotype, along with rhodopsin accumulation (Midorikawa et al., 2010). Moreover, Chen and colleagues recently demonstrated that heterozygous Beclin-1 deficiency or rod photoreceptor-specific Atg7 deficiency increased the susceptibility to lightinduced retinal degeneration in mice. Interestingly, in contrast to severe neuropathology in the $A \operatorname{tg} 7^{-/-}$brain, its deficiency in rod photoreceptors cells does not show overt abnormality in retinal structure at least by the ages of 6 months (Chen et al., 2013), suggesting that in mammalian photoreceptor cells, autophagy may be more involved in the stress response against photooxidative damage than maintaining visual metabolism in normal conditions.

The roles of autophagy in RD have been relatively less investigated. Recently, Besirli and colleagues reported that the levels of Atg5 and LC3-II are elevated in the rat retina after RD in a Fas-dependent manner. Treatment with 3-MA or knockdown of Atg5 exacerbates photoreceptor cell loss after RD, along with increased activity of caspase-8 (Besirli et al., 2011). These findings suggest that Fas activates both autophagic and apoptotic pathways, where autophagy negatively regulates caspase-dependent apoptosis; however, the detailed mechanisms have not been fully elucidated.

In human autopsy samples of RP, Szamier and Berson reported that autophagic vacuoles are observed in the cytoplasm of remaining cone photoreceptor cells (Szamier and Berson, 1977). In a mouse model of RP, we confirmed that whereas rod photoreceptor cells mainly die through apoptosis, the subsequent cone cell death shows necrotic features and accumulation of autophagic vacuoles (Murakami et al., 2012b). Punzo and colleagues demonstrated gene expression changes in the insulin/mTOR pathway during cone degeneration in microarray analysis of RP models. Treatment with insulin delays cone cell death in $r d 1$ mice (Punzo et al., 2009); however, whether this effect is mediated through suppressing autophagy or directly activating pro-survival pathways (such as Akt) remain to be addressed in further studies.

Taken together, autophagy is activated in response to various stresses to photoreceptor cells. In most cases, autophagy appears to protect photoreceptor cells against cellular damage; however it may also mediate cell death when activated excessively. Defining the roles of autophagy in retinal degeneration warrants further studies using tissue-specific knockout mice or more specific autophagy inhibitors.

\section{Mitochondria and cell death}

\subsection{Mitochondrial outer membrane permeabilization}

While mitochondria are double-membrane metabolic organelles that help cells to live, they also function as a critical regulator of cell death through the mitochondrial outer membrane permeabilization (MOMP) and the release of IMS proteins (Tait and Green, 2010). As described above, the release of cytochrome $c$ triggers the apoptosome formation and caspase-9 activation. On the other hand, released AIF translocates into the nucleus and mediates caspase-independent cell death, either apoptosis or necrosis (Artus et al., 2010; Susin et al., 1999). Smac supports caspase activation by interacting with IAP proteins, whereas it also promotes RIP kinase-dependent necrosis in conditions where caspases are inhibited (Vanlangenakker et al., 2010). Therefore, MOMP is involved in both apoptotic and necrotic signaling. 
There are at least two distinct mechanisms for MOMP. Firstly, pro-death Bcl-2 family proteins such as Bax and Bak form membrane pores through oligomerization, allowing for the release of cytochrome $c$ and other IMS proteins (Cheung et al., 2005; Suzuki et al., 2000). Bax/Bak are localized in the cytosol in normal conditions; however, on activation by $\mathrm{BH} 3$-only proteins, Bax and Bak undergo conformational change that exposes the $\mathrm{BH} 3$ domain and hydrophobic groove, leading to oligomerization and translocation to the mitochondrial outer membrane (Czabotar et al., 2013; Dewson et al., 2008; Hsu et al., 1997) (Fig. 6A and B). MOMP also occurs secondary to the mitochondrial permeability transition (MPT) induced by the opening of pre-existing mitochondrial channels such as the permeability transition pore complex (PTPC) (Brenner and Grimm, 2006). PTPC is a polyprotein complex formed at the junction between the inner and outer mitochondrial membrane; it is composed of voltage-dependent anion channel (VDAC) in the outer membrane, adenine nucleotide translocator (ANT) in the inner membrane, and cyclophilin D in the matrix. Bax directly interacts with ANT and regulates its opening at least in part (Marzo et al., 1998). PTPC opening induces an influx of fluid into the matrix, which results in mitochondrial swelling and the rupture of mitochondrial outer membrane (Fig. 6A and C). Overexpression studies have suggested the role of MPT in both apoptosis and necrosis (Baines et al., 2005; Li et al., 2004). However, genetic knockout experiments have shown that cyclophilin D-dependent MPT is essential for necrotic cell death induced by $\mathrm{Ca}^{2+}$ overload or oxidative stress, but not for death receptor- or staurosporine-induced apoptosis (Baines et al., 2005; Nakagawa et al., 2005), suggesting that MPT may be more preferentially involved in necrotic cell death (Galluzzi and Kroemer, 2008).

\subsection{Regulation of mitochondrial integrity by $\mathrm{Bcl}-2$ family proteins}

MOMP is tightly controlled by the balance and interaction between pro-survival and prodeath members of Bcl-2 family proteins. They are divided into three categories based on their structure and function: 1) the pro-survival Bcl-2 members that share all Bcl-2 homology domain 1 (BH1), BH2, BH3 and BH4 (e.g. Bcl-2, Bcl-xl); 2) the 'BH3-only' prodeath members, which possess only a nine amino acid BH3 (e.g. Bid, Bim, PUMA, Bmf, $\mathrm{Bad}$, Noxa); and 3) the multi-domain pro-death members, which contain $\mathrm{BH} 1, \mathrm{BH} 2$ and BH3 (e.g. Bax, Bak) (Tait and Green, 2010) (Fig. 6A).

The pro-survival Bcl-2 proteins are the mammalian homolog of CED-9 in C. elegans, which negatively regulates CED-3/caspases and CED-4/Apaf-1 (Lettre and Hengartner, 2006). These Bcl-2-like proteins control membrane integrity and are located on the cytoplasmic surface of the mitochondria and endoplasmic reticulum (ER). The overexpression of Bcl-2 is associated with carcinogenesis in B-cell lymphoma and other tumors (Tsujimoto et al., 1985), and prevents cell death induced by mitochondrial and/or ER stresses (Vaux et al., 1988).

In contrast, BH3-only proteins are homologs of the EGL-1 protein (encoded by the egglaying defective- 1 gene in C. elegans), which acts upstream of CED-9 as an initiator of cell death. There are at least 10 mammalian BH3-only proteins, which activate Bax/Bak by diverse and redundant mechanisms. For example, caspase-8-dependent cleavage of Bid mediates its translocation to the mitochondrial outer membrane, where the cleaved Bid interacts with Bax and induces its oligomerization (Lovell et al., 2008). On the other hand, Bim and PUMA are activated in response to ER stress or DNA damage (Puthalakath et al., 1999; Puthalakath et al., 2007; Reimertz et al., 2003). Bim is normally sequestered to the microtubule-associated dynein motor complex; however, cellular stress disrupts its interaction. The free Bim directly activates Bax or inactivates pro-survival activity of Bcl-2 (Gavathiotis et al., 2010; Gavathiotis et al., 2008). Increased PUMA expression following DNA damage promotes Bax activation by directly interacting with Bax or by disrupting the 
interaction between Bcl-xl and p53, allowing p53-dependent Bax/Bak activation (Follis et al., 2013; Zhang et al., 2009b). Bmf is involved in anoikis (from Greek "without home"), a mechanism cell death caused by the loss of cell attachment and integrin signaling. Bmf is released from the myosin $\mathrm{V}$ actin motor complex in response to the stimuli that affect the actin cytoskeleton, thereby binding and inactivating Bcl-2-like proteins (Puthalakath et al., 2001). Both Bim and Bmf are substrates of the stress-activated proteins kinase, c-Jun $\mathrm{NH}$ (2)-terminal kinase (JNK), and their phosphorylation by activated JNK induces their release from the motor complexes (Lei and Davis, 2003). Surprisingly, recent genome-wide siRNA screens have identified Bmf as a crucial component of RIP kinase-dependent necrosis (Hitomi et al., 2008), although the precise mechanisms by which Bmf is activated during necrosis and mediates RIP kinase activation remain elusive.

\subsection{MOMP as a target of neuroprotection in RD}

The mitochondrial release of IMS proteins, such as cytochrome $c$ and AIF, contributes to photoreceptor cell death after RD (Hisatomi et al., 2008; Hisatomi et al., 2001). Therefore, the blockade of MOMP may be a potential strategy to prevent the release of IMS proteins and the subsequent photoreceptor cell death. Indeed, Yang and colleagues showed that the photoreceptor cell loss after RD is substantially reduced in $\mathrm{Bax}^{-/-}$mice (Yang et al., 2004b). Consistently, treatment with the cell-permeable BH4 domain peptide of Bcl-xl prevents photoreceptor cell death after experimental RD, along with the suppression of caspase-9 activity and reduced AIF translocation (Hisatomi et al., 2008). These findings suggest that the regulation of mitochondrial integrity by Bcl-2 family proteins is critical for photoreceptor cell death after RD. In addition, Hisatomi and colleagues demonstrated that HIV protease inhibitors (PIs) provide protection of photoreceptor cells in experimental RD (Hisatomi et al., 2008). Besides their effect on HIV replication, PIs have been shown in recent studies to also inhibit cell death through interacting with ANT and preventing PTPC opening (Weaver et al., 2005). Systemic oral administration of PIs prevents photoreceptor cell death as well as the release and activation of IMS proteins after RD. These findings suggest that in addition to Bax channels, PTPC pores contribute to the loss of mitochondrial membrane integrity in dying photoreceptors.

Although the involvement of BH3-only proteins in RD has not been fully elucidated, Zacks and colleagues showed that Bid is transcriptionally upregulated and cleaved to its active form in mouse retinas after RD (Zacks et al., 2004). Because Bid is cleaved by active caspase-8, Bid may mediate MOMP and photoreceptor apoptosis in downstream of caspase signaling. In addition, Bmf would be an interesting BH3-only protein that could be involved in $\mathrm{RD}$, because $\mathrm{Bmf}$ is activated in cells detaching from the surrounding extracellular matrix and mediates RIP kinase-dependent necrosis (Puthalakath et al., 2001; Hitomi et al., 2008). Further studies will be needed to clarify which BH3-only proteins are activated and play pivotal roles in photoreceptor cell death after RD.

\subsection{The role of MOMP in other retinal degenerative diseases}

In a light injury model, Hahn and colleagues reported that combined deficiency of Bax and $B a k$ prevents photoreceptor cell loss more effectively than Bax deficiency (Hahn et al., 2004). Conversely, rod photoreceptor-specific knockout of $B c l$-xl increases the susceptibility to light injury (Zheng et al., 2006). Furthermore, transgenic overexpression of $\mathrm{Bcl}-2 \mathrm{or} \mathrm{Bcl}$ $x l$ ameliorates light-induced retinal degeneration (Chen et al., 1996; Joseph and Li, 1996), confirming that Bcl-2 family proteins are critical regulators of photoreceptor cell death after light injury.

In RP models, Bax deficiency alone does not prevent photoreceptor cell death in $r d 1$ mice, an RP model with the Pde6b mutation (Mosinger Ogilvie et al., 1998). The effect of Bax and

Prog Retin Eye Res. Author manuscript; available in PMC 2014 November 01. 
Bak double knockout on retinal degeneration in RP models has not been tested yet. The results from $\mathrm{Bcl}-2$ overexpression in RP models are controversial: transgenic overexpression of $B c l-2$ delayed photoreceptor degeneration in $r d l$ mice or rhodopsin mutant mice in one study (Chen et al., 1996), but did not show any protection in another study (Joseph and Li, 1996).

Cotter and colleagues investigated the role of Bim in retinal cell death during development and degeneration. They showed that Bim is highly expressed during postnatal retinal development but substantially decreased thereafter (McKernan et al., 2007). Developmental apoptosis of retinal neurons is delayed in $\mathrm{Bim}^{-/-}$mice, confirming that Bim is important for cell elimination during development (Doonan et al., 2007). Although the expression level of Bim is low in adult ganglion cells, it is substantially upregulated and contributes to retinal ganglion cell death after optic nerve crush injury (Harder et al., 2012). In contrast, Bim remains to be absent in the retinas of $r d 1$ mice (Doonan et al., 2007), suggesting that Bim may not be involved in retinal degeneration caused by $P \operatorname{de} 6 \beta$ mutation. In addition, the glacomatous retinal ganglion cell death in DBA/2J mice is not rescued by Bim deficiency (Harder et al., 2012). These finding suggest that Bcl-2 family proteins may differentially contribute to the retinal cell death depending on its causes and conditions, and further studies may deepen the understanding of the role of MOMP in retinal degeneration.

\section{Inflammation and cell death}

\section{1. Interaction between dying cells and phagocytes}

Clearance of cellular corpes by phagocytes is a classical feature of apoptosis. Previous TEM studies of developmental cell death showed that fragmented apoptotic bodies are engulfed and digested by neighboring cells or professional phagocytes such as macrophages (Schweichel and Merker, 1973). An important aspect of this process is the lack of severe inflammation and tissue scarring. Further studies have revealed the molecular mechanisms by which apoptotic cells are recognized by phagocytes and modulate inflammatory response. For example, when cells undergo apoptosis, they release "find-me" signals such as nucleotides and lipid mediators to attract phagocytes. Surface exposed PS on apoptotic cells binds to receptors on phagocytes and acts as an "eat-me" signal to facilitate the engulfment of apoptotic cells by phagocytes. In addition, apoptotic corpes mediates the intracellular signaling to repress pro-inflammatory cytokine production and promotes immune tolerance (Ravichandran, 2011). Inappropriate clearace of apoptotic cells can lead to non-resolving inflammation and has been linked to autoimmune disorders and developmental abnormalities (Nathan and Ding, 2010; Nagata et al., 2010).

In contrast, necrosis is generally thought to be immunogenic. Intracellular macromolecules released from necrotic cells act as damage-associated molecular patterns (DAMPs) that activate inflammatory receptors such as TLRs. Among them, high-mobility group box 1 (HMGB1) is one of the most characterized DAMPs released from necrotic cells (Lotze and Tracey, 2005). Although HMGB1 is a nuclear protein that regulates transcription activity, extracellular HMGB-1 promotes inflammation through the interaction with TLRs. HMGB1 levels are increased in the serum of patients with sepsis (Wang et al., 1999), and neutralization of HMGB1 reverses the lethality of animal models of sepsis (Yang et al., 2004a). Furthermore, Duprez and colleagues reported that Rip3 deficiency prevents the extracellular release of HMGB1 and protects mice from lethal sepsis (Duprez et al., 2011). These findings suggest that necrosis and the subsequent release of DAMPs may be a key inflammatory mediator in sepsis. Besides HMGB1, multiple proteins, nucleic acids and organelles, such as S100, HSP, histones, DNA, mRNA, and damaged mitochondria are shown to function as DAMPs when they are released into the extracellular space (Zitvogel et al., 2010). 
Nonetheless, this concept that apoptosis is tolerogenic while necrosis is immunogenic has been challenged in certain conditions. Casares and colleagues showed that tumor cells undergoing caspase-dependent apoptosis in response to chemotherapy can elicit an effective anti-tumor immune response (Casares et al. 2005). On the other hand, necrotic cells can be engulfed by macrophages without producing inflammatory cytokines (Hirt and Leist, 2003; Brouckaert et al., 2004). These findings suggest that immunological response may be related not only to cell death modes but also to the types and intensity of cell death stimuli, the amount of dying cells, and phagocyte activity.

\subsection{Inflammatory signals from dying photoreceptor cells}

The extracellular exposure of PS is the most-characterized "eat-me" signal for phagocytes (Ravichandran, 2011). PS is a phospholipid component, which is usually present in the inner leaflet of the plasma membrane. However, when cells undergo apoptosis (or necrosis in certain conditions), PS is exposed to the outer leaflet together with other plasma membrane lipids in caspase-dependent and caspase-independent manners (Krysko et al., 2004). There are multiple receptors on macrophages that recognize PS exposure, such as CD36 and the T cell immunoglobulin and mucin family receptors (Miyanishi et al., 2007). PS exposure and its recognition by the phagocyte receptors are critical for the engulfment of dying cells. In experimental RD, Hisatomi and colleagues demonstrated that blockade of the interaction between PS and its receptors leads to the accumulation of cell debris in the subretinal space (Hisatomi et al., 2003), indicating that macrophage-mediated phagocytosis is critical for the clearance of dying photoreceptor cells after RD.

Extracellular release of ATP is a key "find-me" signal to recruit macrophages to the site of injury (Davalos et al., 2005). ATP is secreted actively by exocytosis, anion channels, or transporters in an early phase of apoptosis, or released passively via the loss of membrane integrity. Extracellular ATP is sensed by the purinergic P2Y2 receptor expressed on macrophages. ATP also activates the inflammasome through its action on P2X7, or mediates cell death via the formation of P2X7-dependent pore and caspase activation (Khakh and North, 2006). Notomi and colleagues showed that intraocular injection of ATP induces photoreceptor cell death through the activation of $\mathrm{P} 2 \mathrm{X} 7$ in mice and primary retinal cultures (Notomi et al., 2011). In addition, extracellular ATP is substantially increased in the vitreous of patients with subretinal hemorrhage associated with AMD (Notomi et al., 2013). The involvement of ATP release in other retinal degenerative diseases and its roles on cell death and inflammation warrant further investigation.

High-mobility group box 1 (HMGB1), a nuclear protein that regulates transcription, has a divergent extracellular function as a DAMP (Lotze and Tracey, 2005). HMGB1 is passively released from necrotic cells but not from apoptotic cells (Scaffidi et al., 2002). HMGB1 is also actively secreted in response to LPS or TNF-a through its acetylation (Bonaldi et al., 2003). Extracellular HMGB-1 binds and activates TLR2, TLR4 and receptor for advanced glycation end products, and enhances pro-inflammatory cytokine production. Arimura and colleagues showed that the extracellular release of HMGB1 occurrs in human patients and experimental models of RD (Arimura et al., 2009), suggesting that HMGB1 released from dying or dead photoreceptor cells may modulate retinal inflammatory response and degeneration after RD (Fig. 7). We recently investigated the role of RIP kinase in retinal degeneration induced by dsRNA, a component of drusen in AMD. Our study showed that the necrosis of RPE and retinal inflammation are attenuated in $R i p 3^{-/-}$mice, along with decreased levels of intravitreal release of HMGB1. In vitro, Rip 3 deficiency inhibits the release of HMGB1 from necrotic RPE cells and dampens pro-inflammatory cytokine induction evoked by necrotic components. On the other hand, it does not modulate directly pro-inflammatory cytokine production after dsRNA stimulation (Murakami et al., 2013).

Prog Retin Eye Res. Author manuscript; available in PMC 2014 November 01. 
These findings suggest that the release of DAMPs from necrotic cells may contribute to inflammatory amplification in retinal degenerative diseases such as AMD. Further investigation of the roles of DAMPs in retinal degeneration will lead to better understanding of the pathogenesis of the diseases and identification of novel therapeutic targets.

\subsection{Production of cytokines/chemokines and macrophage infiltration after RD}

Cytokines and chemokines are released in response to tissue injury and mediate cell survival/death and inflammation. In human RD surgical samples, transcriptome analysis has revealed enriched clusters demonstrating inflammatory responses and co-regulation of genes involved in photoreceptor degeneration (Delyfer et al., 2011), indicating that these two pathological processes are closely linked in RD. Multiplex analysis of subretinal fluid shows significantly higher levels of IL-6 and various chemokines in rhegmatogenous RD patients who developed redetachments due to postsurgical proliferative vitreoretinopathy (Ricker et al., 2010). The vitreous fluid from patients with RD also contains substantially higher levels of TNF-a, IL-1 $\beta$, IL-6, IL-8 and MCP-1, compared to samples from patients without RD (Bakunowicz-Lazarczyk et al., 1997; Yoshimura et al., 2009). Furthermore, Nakazawa and colleagues showed that the mRNA levels of TNF- $a$, IL-1 $\beta$ and MCP-1 are up-regulated as early as $1 \mathrm{hr}$ after experimental RD, suggesting that these cytokines/chemokines may actively contribute to the pathology of RD (Nakazawa et al., 2006). Indeed, as described above, TNF-a induces photoreceptor cell death after RD along with the activation of caspase-8 and RIP kinase. In addition, blockade of TNF-a suppresses the retinal infiltration of macrophages and microglial cells (Nakazawa et al., 2011; Trichonas et al., 2010). Therefore, not only pro-death but also pro-inflammatory signals of TNF-a could be involved in photoreceptor loss after RD. In another study by Nakazawa and colleagues, genetic deficiency of $M c p 1$ substantially reduces macrophage/microglia recruitment and attenuates photoreceptor cell loss after RD. In primary retinal mixed cultures, MCP-1 treatment induces photoreceptor cell loss; however, this cytotoxic effect is abolished by the removal of CD11b-positive macrophages/microglia from the retinal cultures (Nakazawa et al., 2007). These findings suggest that MCP-1 mediates photoreceptor cell death indirectly through activation and recruitment of macrophages/microglia after RD. Protection against RDinduced photoreceptor cell death is also obtained by genetic deletion of $\mathrm{Cd} 1 \mathrm{lb} / \mathrm{Cd} 18$, an integrin critical for leukocyte recruitment, or with the treatment with systemic steroids (Nakazawa et al., 2007; Nakazawa et al., 2011), further confirming the pivotal role of inflammation in photoreceptor cell loss after RD (Fig. 7). However, it should be noted that inflammation is not always detrimental, but may also maintain tissue homeostasis by removing waste materials and dead cells. Recent studies have shown that two distinct macrophage subsets, i.e., 'classically activated' pro-inflammatory (M1) or 'alternatively activated' anti-inflammatory (M2) cells, play divergent roles during neurodegeneration. Cao and colleagues showed that advanced AMD macula contain a higher M1 to M2 chemokine transcript compared with aging non-AMD eyes (Cao et al. 2011). Although the function of M1 and M2 macrophages in retinal degeneration remain elusive, Kigerl and collegues reported that M1 macrophages are neurotoxic while M2 macrophages promote axonal regeneration in cultured cortical neurons (Kigerl et al., 2009). In experimental autoimmune encephalitis, polarization to the M1 phenotype leads to enhanced demyelination and brain inflammation, which is reversed by the adaptive transfer of M2 macrophages (Qin et al., 2012). Therefore, the 'neurotoxic' subset of macrophages may be a potential target for the treatment of neurodegeneration, and characterization of macrophage subsets in RD and other retinal diseases will be an interesting area of future studies. 


\section{Conclusions}

Photoreceptor cell death is the ultimate cause of vision loss in RD and other retinal degenerative disorders. Apoptosis is the best-characterized form of programmed cell death; since the term was coined by Kerr and colleagues from morphological observation, a body of genetic and biochemical investigation has identified the key molecules that initiate and execute apoptosis. Furthermore, studies have implicated the involvement of apoptosis in the process of development as well as the pathogenesis of various disorders including retinal degeneration. However, despite more than a decade of work, attempts to achieve neuroprotection by pharmacologically targeting apoptosis have largely failed. Recent progress in cell death research has demonstrated that non-apoptotic forms of cell death, such as autophagy and necrosis, are also highly regulated and active processes. In clinically relevant models of RD, we and others have shown that not only apoptotic but also nonapoptotic pathways contribute to photoreceptor cell death, and that simultaneously targeting key mediators in both pathways (e.g., caspases and RIP kinase) is effective in preventing photoreceptor cell loss. These findings provide new insights into the molecular mechanisms of photoreceptor cell death; however, there remain many unanswered questions. Given the redundancy and crosstalk between apoptotic, autophagic, and necrotic pathways, it is important to clarify what factors determine the predominance of a particular pathway and photoreceptor cell fate. Undoubtedly, there are RIP kinase-independent mechanisms to induce necrosis, which remain to be elucidated. Although it seems reasonable that autophagy is activated in the starved photoreceptor cells after RD, its detailed function remains to be elucidated. The regulatory roles of mitochondria in each cell death type and the interaction between cell death and inflammation during retinal degeneration warrants further investigation. We believe that further dissection of the complex molecular mechanisms underlying photoreceptor cell death will lead to better understanding of the pathophysiology of RD and developing novel therapeutics for preventing vision deficits due to photoreceptor cell loss.

\section{Acknowledgments}

We thank Wendy Chao for her critical review and support for the manuscript. This work was supported by Harvard Ophthalmology Department Support (DGV), NIH grant R21EY023079-01A1 (DGV), Research to Prevent Blindness Physician Scientist Award (DGV), Foundation Lions Eye Research Fund (DGV), The Yeatts Family Foundation (JWM , DGV) and Rena Family Foundation (JWM, DGV), NEI grant EY014104 (MEEI Core Grant), and the Japanese Ministry of Education, Culture, Sports, Science, and Technology grant 25861637 (YM).

\section{References}

Ambati J, Anand A, Fernandez S, Sakurai E, Lynn BC, Kuziel WA, Rollins BJ, Ambati BK. An animal model of age-related macular degeneration in senescent Ccl-2- or Ccr-2-deficient mice. Nat Med. 2003; 9:1390-1397. [PubMed: 14566334]

Anderson DH, Stern WH, Fisher SK, Erickson PA, Borgula GA. The onset of pigment epithelial proliferation after retinal detachment. Invest Ophthalmol Vis Sci. 1981; 21:10-16. [PubMed: 7251293]

Andley UP. Crystallins in the eye: Function and pathology. Prog Retin Eye Res. 2007; 26:78-98. [PubMed: 17166758]

Bode C, Wolfrum U. Caspase-3 inhibitor reduces apototic photoreceptor cell death during inherited retinal degeneration in tubby mice. Mol Vis. 2003; 9:144-150. [PubMed: 12724642]

Arimura N, Ki-i Y, Hashiguchi T, Kawahara K, Biswas KK, Nakamura M, Sonoda Y, Yamakiri K, Okubo A, Sakamoto T, Maruyama I. Intraocular expression and release of high-mobility group box 1 protein in retinal detachment. Lab Invest. 2009; 89:278-289. [PubMed: 19139725]

Arroyo JG, Yang L, Bula D, Chen DF. Photoreceptor apoptosis in human retinal detachment. Am J Ophthalmol. 2005; 139:605-610. [PubMed: 15808154]

Prog Retin Eye Res. Author manuscript; available in PMC 2014 November 01. 
Artus C, Boujrad H, Bouharrour A, Brunelle MN, Hoos S, Yuste VJ, Lenormand P, Rousselle JC, Namane A, England P, Lorenzo HK, Susin SA. AIF promotes chromatinolysis and caspaseindependent programmed necrosis by interacting with histone H2AX. Embo J. 2010; 29:1585-1599. [PubMed: 20360685]

Baines CP, Kaiser RA, Purcell NH, Blair NS, Osinska H, Hambleton MA, Brunskill EW, Sayen MR, Gottlieb RA, Dorn GW, Robbins J, Molkentin JD. Loss of cyclophilin D reveals a critical role for mitochondrial permeability transition in cell death. Nature. 2005; 434:658-662. [PubMed: 15800627]

Bakunowicz-Lazarczyk A, Moniuszko T, Stankiewicz A, Mrugacz M. [Concentration of selected cytokines in subretinal fluid in patients with retinal detachment (IL-8, TNF-alpha, IFN-gamma)]. Klin Oczna. 1997; 99:87-89. [PubMed: 9379667]

Barber AJ, Lieth E, Khin SA, Antonetti DA, Buchanan AG, Gardner TW. Neural apoptosis in the retina during experimental and human diabetes. Early onset and effect of insulin. J Clin Invest. 1998; 102:783-791. [PubMed: 9710447]

Baskin-Bey ES, Washburn K, Feng S, Oltersdorf T, Shapiro D, Huyghe M, Burgart L, Garrity-Park M, van Vilsteren FG, Oliver LK, Rosen CB, Gores GJ. Clinical Trial of the Pan-Caspase Inhibitor, IDN-6556, in Human Liver Preservation Injury. Am J Transplant. 2007; 7:218-225. [PubMed: 17227570]

Besirli CG, Chinskey ND, Zheng QD, Zacks DN. Inhibition of retinal detachment-induced apoptosis in photoreceptors by a small peptide inhibitor of the fas receptor. Invest Ophthalmol Vis Sci. 2010; 51:2177-2184. [PubMed: 19850829]

Besirli CG, Chinskey ND, Zheng QD, Zacks DN. Autophagy activation in the injured photoreceptor inhibits fas-mediated apoptosis. Invest Ophthalmol Vis Sci. 2011; 52:4193-4199. [PubMed: 21421874]

Biton S, Ashkenazi A. NEMO and RIP1 control cell fate in response to extensive DNA damage via TNF-alpha feedforward signaling. Cell. 2011; 145:92-103. [PubMed: 21458669]

Bjorkoy G, Lamark T, Brech A, Outzen H, Perander M, Overvatn A, Stenmark H, Johansen T. p62/ SQSTM1 forms protein aggregates degraded by autophagy and has a protective effect on huntingtin-induced cell death. J Cell Biol. 2005; 171:603-614. [PubMed: 16286508]

Blommaart EF, Krause U, Schellens JP, Vreeling-Sindelarova H, Meijer AJ. The phosphatidylinositol 3-kinase inhibitors wortmannin and LY294002 inhibit autophagy in isolated rat hepatocytes. European journal of biochemistry / FEBS. 1997; 243:240-246. [PubMed: 9030745]

Bonaldi T, Talamo F, Scaffidi P, Ferrera D, Porto A, Bachi A, Rubartelli A, Agresti A, Bianchi ME. Monocytic cells hyperacetylate chromatin protein HMGB1 to redirect it towards secretion. Embo J. 2003; 22:5551-5560. [PubMed: 14532127]

Bonapace L, Bornhauser BC, Schmitz M, Cario G, Ziegler U, Niggli FK, Schafer BW, Schrappe M, Stanulla M, Bourquin JP. Induction of autophagy-dependent necroptosis is required for childhood acute lymphoblastic leukemia cells to overcome glucocorticoid resistance. J Clin Invest. 2010; 120:1310-1323. [PubMed: 20200450]

Bonnet MC, Preukschat D, Welz PS, van Loo G, Ermolaeva MA, Bloch W, Haase I, Pasparakis M. The adaptor protein FADD protects epidermal keratinocytes from necroptosis in vivo and prevents skin inflammation. Immunity. 2011; 35:572-582. [PubMed: 22000287]

Bossaller L, Chiang PI, Schmidt-Lauber C, Ganesan S, Kaiser WJ, Rathinam VA, Mocarski ES, Subramanian D, Green DR, Silverman N, Fitzgerald KA, Marshak-Rothstein A, Latz E. Cutting edge: FAS (CD95) mediates noncanonical IL-1beta and IL-18 maturation via caspase-8 in an RIP3-independent manner. J Immunol. 2012; 189:5508-5512. [PubMed: 23144495]

Boya P, Gonzalez-Polo RA, Casares N, Perfettini JL, Dessen P, Larochette N, Metivier D, Meley D, Souquere S, Yoshimori T, Pierron G, Codogno P, Kroemer G. Inhibition of macroautophagy triggers apoptosis. Mol Cell Biol. 2005; 25:1025-1040. [PubMed: 15657430]

Brenner C, Grimm S. The permeability transition pore complex in cancer cell death. Oncogene. 2006; 25:4744-4756. [PubMed: 16892087]

Brouckaert G, Kalai M, Krysko DV, Saelens X, Vercammen D, Ndlovu MN, Haegeman G, D'Herde $\mathrm{K}$, Vandenabeele P. Phagocytosis of necrotic cells by macrophages is phosphatidylserine 
dependent and does not induce inflammatory cytokine production. Mol Biol Cell. 2004; 15:10891100. [PubMed: 14668480]

Brown D, Yu BD, Joza N, Benit P, Meneses J, Firpo M, Rustin P, Penninger JM, Martin GR. Loss of Aif function causes cell death in the mouse embryo, but the temporal progression of patterning is normal. Proc Natl Acad Sci U S A. 2006; 103:9918-9923. [PubMed: 16788063]

Buytaert E, Callewaert G, Vandenheede JR, Agostinis P. Deficiency in apoptotic effectors Bax and Bak reveals an autophagic cell death pathway initiated by photodamage to the endoplasmic reticulum. Autophagy. 2006; 2:238-240. [PubMed: 16874066]

Callus BA, Vaux DL. Caspase inhibitors: viral, cellular and chemical. Cell Death Differ. 2007; 14:7378. [PubMed: 16946729]

Campo RV, Sipperley JO, Sneed SR, Park DW, Dugel PU, Jacobsen J, Flindall RJ. Pars plana vitrectomy without scleral buckle for pseudophakic retinal detachments. Ophthalmology. 1999; 106:1811-1815. discussion 1816. [PubMed: 10485555]

Camardo J. The Rapamune era of immunosuppression 2003: the journey from the laboratory to clinical transplantation. Transplant Proc. 2003; 35:18S-24S. [PubMed: 12742464]

Cande C, Vahsen N, Kouranti I, Schmitt E, Daugas E, Spahr C, Luban J, Kroemer RT, Giordanetto F, Garrido C, Penninger JM, Kroemer G. AIF and cyclophilin A cooperate in apoptosis-associated chromatinolysis. Oncogene. 2004; 23:1514-1521. [PubMed: 14716299]

Cao X, Shen D, Patel MM, Tuo J, Johnson TM, Olsen TW, Chan CC. Macrophage polarization in the maculae of age-related macular degeneration: a pilot study. Pathol Int. 2011; 61:528-535. [PubMed: 21884302]

Caro LH, Plomp PJ, Wolvetang EJ, Kerkhof C, Meijer AJ. 3-Methyladenine, an inhibitor of autophagy, has multiple effects on metabolism. European journal of biochemistry / FEBS. 1988; 175:325-329. [PubMed: 3402459]

Casares N, Pequignot MO, Tesniere A, Ghiringhelli F, Roux S, Chaput N, Schmitt E, Hamai A, Hervas-Stubbs S, Obeid M, Coutant F, Metivier D, Pichard E, Aucouturier P, Pierron G, Garrido C, Zitvogel L, Kroemer G. Caspase-dependent immunogenicity of doxorubicin-induced tumor cell death. J Exp Med. 2005; 202:1691-1701. [PubMed: 16365148]

Cecconi F, Alvarez-Bolado G, Meyer BI, Roth KA, Gruss P. Apaf1 (CED-4 homolog) regulates programmed cell death in mammalian development. Cell. 1998; 94:727-737. [PubMed: 9753320]

Chang B, Hawes NL, Hurd RE, Davisson MT, Nusinowitz S, Heckenlively JR. Retinal degeneration mutants in the mouse. Vision Res. 2002; 42:517-525. [PubMed: 11853768]

Chan FK, Shisler J, Bixby JG, Felices M, Zheng L, Appel M, Orenstein J, Moss B, Lenardo MJ. A role for tumor necrosis factor receptor-2 and receptor-interacting protein in programmed necrosis and antiviral responses. J Biol Chem. 2003; 278:51613-51621. [PubMed: 14532286]

Chang GQ, Hao Y, Wong F. Apoptosis: final common pathway of photoreceptor death in rd, rds, and rhodopsin mutant mice. Neuron. 1993; 11:595-605. [PubMed: 8398150]

de Jong PT. Age-related macular degeneration. N Engl J Med. 2006; 355:1474-1485. [PubMed: 17021323]

Chang M, Jin W, Sun SC. Peli1 facilitates TRIF-dependent Toll-like receptor signaling and proinflammatory cytokine production. Nat Immunol. 2009; 10:1089-1095. [PubMed: 19734906]

Chang Q, Peter ME, Grassi MA. Fas ligand-Fas signaling participates in light-induced apoptotic death in photoreceptor cells. Invest Ophthalmol Vis Sci. 2012; 53:3703-3716. [PubMed: 22499988]

Chen J, Flannery JG, LaVail MM, Steinberg RH, Xu J, Simon MI. bcl-2 overexpression reduces apoptotic photoreceptor cell death in three different retinal degenerations. Proc Natl Acad Sci U S A. 1996; 93:7042-7047. [PubMed: 8692941]

Chen Y, Sawada O, Kohno H, Le YZ, Subauste C, Maeda T, Maeda A. Autophagy protects the retina from light-induced degeneration. J Biol Chem. 2013

Cheung EC, Joza N, Steenaart NA, McClellan KA, Neuspiel M, McNamara S, MacLaurin JG, Rippstein P, Park DS, Shore GC, McBride HM, Penninger JM, Slack RS. Dissociating the dual roles of apoptosis-inducing factor in maintaining mitochondrial structure and apoptosis. Embo J. 2006; 25:4061-4073. [PubMed: 16917506]

Cheung EC, Melanson-Drapeau L, Cregan SP, Vanderluit JL, Ferguson KL, McIntosh WC, Park DS, Bennett SA, Slack RS. Apoptosis-inducing factor is a key factor in neuronal cell death propagated 
by BAX-dependent and BAX-independent mechanisms. J Neurosci. 2005; 25:1324-1334. [PubMed: 15703386]

Cho Y, McQuade T, Zhang H, Zhang J, Chan FK. RIP1-dependent and independent effects of necrostatin-1 in necrosis and T cell activation. PLoS One. 2011; 6:e23209. [PubMed: 21853090]

Cho YS, Challa S, Moquin D, Genga R, Ray TD, Guildford M, Chan FK. Phosphorylation-driven assembly of the RIP1-RIP3 complex regulates programmed necrosis and virus-induced inflammation. Cell. 2009; 137:1112-1123. [PubMed: 19524513]

Chong DY, Boehlke CS, Zheng QD, Zhang L, Han Y, Zacks DN. Interleukin-6 as a photoreceptor neuroprotectant in an experimental model of retinal detachment. Invest Ophthalmol Vis Sci. 2008; 49:3193-3200. [PubMed: 18378582]

Christofferson DE, Li Y, Hitomi J, Zhou W, Upperman C, Zhu H, Gerber SA, Gygi S, Yuan J. A novel role for RIP1 kinase in mediating TNFalpha production. Cell Death Dis. 2012; 3:e320. [PubMed: 22695613]

Churbanova IY, Sevrioukova IF. Redox-dependent changes in molecular properties of mitochondrial apoptosis-inducing factor. J Biol Chem. 2008; 283:5622-5631. [PubMed: 18167347]

Clarke PG. Developmental cell death: morphological diversity and multiple mechanisms. Anat Embryol (Berl). 1990; 181:195-213. [PubMed: 2186664]

Clem RJ, Fechheimer M, Miller LK. Prevention of apoptosis by a baculovirus gene during infection of insect cells. Science. 1991; 254:1388-1390. [PubMed: 1962198]

Cook B, Lewis GP, Fisher SK, Adler R. Apoptotic photoreceptor degeneration in experimental retinal detachment. Invest Ophthalmol Vis Sci. 1995; 36:990-996. [PubMed: 7730033]

Crook NE, Clem RJ, Miller LK. An apoptosis-inhibiting baculovirus gene with a zinc finger-like motif. J Virol. 1993; 67:2168-2174. [PubMed: 8445726]

Csak T, Dolganiuc A, Kodys K, Nath B, Petrasek J, Bala S, Lippai D, Szabo G. Mitochondrial antiviral signaling protein defect links impaired antiviral response and liver injury in steatohepatitis in mice. Hepatology. 2011; 53:1917-1931. [PubMed: 21425308]

Culmsee C, Zhu C, Landshamer S, Becattini B, Wagner E, Pellecchia M, Blomgren K, Plesnila N. Apoptosis-inducing factor triggered by poly(ADP-ribose) polymerase and Bid mediates neuronal cell death after oxygen-glucose deprivation and focal cerebral ischemia. J Neurosci. 2005; 25:10262-10272. [PubMed: 16267234]

Cusson-Hermance N, Khurana S, Lee TH, Fitzgerald KA, Kelliher MA. Rip1 mediates the Trifdependent toll-like receptor 3- and 4-induced NF-\{kappa $\}$ B activation but does not contribute to interferon regulatory factor 3 activation. J Biol Chem. 2005; 280:36560-36566. [PubMed: 16115877]

Czabotar PE, Westphal D, Dewson G, Ma S, Hockings C, Fairlie WD, Lee EF, Yao S, Robin AY, Smith BJ, Huang DC, Kluck RM, Adams JM, Colman PM. Bax Crystal Structures Reveal How BH3 Domains Activate Bax and Nucleate Its Oligomerization to Induce Apoptosis. Cell. 2013; 152:519-531. [PubMed: 23374347]

Davalos D, Grutzendler J, Yang G, Kim JV, Zuo Y, Jung S, Littman DR, Dustin ML, Gan WB. ATP mediates rapid microglial response to local brain injury in vivo. Nat Neurosci. 2005; 8:752-758. [PubMed: 15895084]

de Calignon A, Fox LM, Pitstick R, Carlson GA, Bacskai BJ, Spires-Jones TL, Hyman BT. Caspase activation precedes and leads to tangles. Nature. 2010; 464:1201-1204. [PubMed: 20357768]

Degenhardt K, Mathew R, Beaudoin B, Bray K, Anderson D, Chen G, Mukherjee C, Shi Y, Gelinas C, Fan Y, Nelson DA, Jin S, White E. Autophagy promotes tumor cell survival and restricts necrosis, inflammation, and tumorigenesis. Cancer cell. 2006; 10:51-64. [PubMed: 16843265]

Degterev A, Hitomi J, Germscheid M, Ch'en IL, Korkina O, Teng X, Abbott D, Cuny GD, Yuan C, Wagner G, Hedrick SM, Gerber SA, Lugovskoy A, Yuan J. Identification of RIP1 kinase as a specific cellular target of necrostatins. Nat Chem Biol. 2008; 4:313-321. [PubMed: 18408713]

Degterev A, Huang Z, Boyce M, Li Y, Jagtap P, Mizushima N, Cuny GD, Mitchison TJ, Moskowitz MA, Yuan J. Chemical inhibitor of nonapoptotic cell death with therapeutic potential for ischemic brain injury. Nat Chem Biol. 2005; 1:112-119. [PubMed: 16408008]

Degterev A, Maki JL, Yuan J. Activity and specificity of necrostatin-1, small-molecule inhibitor of RIP1 kinase. Cell Death Differ. 2013; 20:366. [PubMed: 23197295] 
Delyfer MN, Raffelsberger W, Mercier D, Korobelnik JF, Gaudric A, Charteris DG, Tadayoni R, Metge F, Caputo G, Barale PO, Ripp R, Muller JD, Poch O, Sahel JA, Leveillard T.

Transcriptomic analysis of human retinal detachment reveals both inflammatory response and photoreceptor death. PLoS One. 2011; 6:e28791. [PubMed: 22174898]

Dewson G, Kratina T, Sim HW, Puthalakath H, Adams JM, Colman PM, Kluck RM. To trigger apoptosis, Bak exposes its $\mathrm{BH} 3$ domain and homodimerizes via $\mathrm{BH} 3$ :groove interactions. Mol Cell. 2008; 30:369-380. [PubMed: 18471982]

Dong K, Zhu H, Song Z, Gong Y, Wang F, Wang W, Zheng Z, Yu Z, Gu Q, Xu X, Sun X. Necrostatin-1 protects photoreceptors from cell death and improves functional outcome after experimental retinal detachment. Am J Pathol. 2012; 181:1634-1641. [PubMed: 22940440]

Donovan M, Cotter TG. Caspase-independent photoreceptor apoptosis in vivo and differential expression of apoptotic protease activating factor-1 and caspase-3 during retinal development. Cell Death Differ. 2002; 9:1220-1231. [PubMed: 12404121]

Doonan F, Donovan M, Cotter TG. Caspase-independent photoreceptor apoptosis in mouse models of retinal degeneration. J Neurosci. 2003; 23:5723-5731. [PubMed: 12843276]

Doonan F, Donovan M, Gomez-Vicente V, Bouillet P, Cotter TG. Bim expression indicates the pathway to retinal cell death in development and degeneration. J Neurosci. 2007; 27:1088710894. [PubMed: 17913922]

Duprez L, Takahashi N, Van Hauwermeiren F, Vandendriessche B, Goossens V, Vanden Berghe T, Declercq W, Libert C, Cauwels A, Vandenabeele P. RIP kinase-dependent necrosis drives lethal systemic inflammatory response syndrome. Immunity. 2011; 35:908-918. [PubMed: 22195746]

Doyle SL, Campbell M, Ozaki E, Salomon RG, Mori A, Kenna PF, Farrar GJ, Kiang AS, Humphries MM, Lavelle EC, O’Neill LA, Hollyfield JG, Humphries P. NLRP3 has a protective role in agerelated macular degeneration through the induction of IL-18 by drusen components. Nat Med. 2012; 18:791-798. [PubMed: 22484808]

Du C, Fang M, Li Y, Li L, Wang X. Smac, a mitochondrial protein that promotes cytochrome cdependent caspase activation by eliminating IAP inhibition. Cell. 2000; 102:33-42. [PubMed: 10929711]

Dunaief JL, Dentchev T, Ying GS, Milam AH. The role of apoptosis in age-related macular degeneration. Arch Ophthalmol. 2002; 120:1435-1442. [PubMed: 12427055]

Duprez L, Takahashi N, Van Hauwermeiren F, Vandendriessche B, Goossens V, Vanden Berghe T, Declercq W, Libert C, Cauwels A, Vandenabeele P. RIP kinase-dependent necrosis drives lethal systemic inflammatory response syndrome. Immunity. 2011; 35:908-918. [PubMed: 22195746]

Ea CK, Deng L, Xia ZP, Pineda G, Chen ZJ. Activation of IKK by TNFalpha requires site-specific ubiquitination of RIP1 and polyubiquitin binding by NEMO. Mol Cell. 2006; 22:245-257. [PubMed: 16603398]

Ellis HM, Horvitz HR. Genetic control of programmed cell death in the nematode C. elegans. Cell. 1986; 44:817-829. [PubMed: 3955651]

Erickson PA, Fisher SK, Anderson DH, Stern WH, Borgula GA. Retinal detachment in the cat: the outer nuclear and outer plexiform layers. Invest Ophthalmol Vis Sci. 1983; 24:927-942. [PubMed: 6862796]

Eskelinen EL. To be or not to be? Examples of incorrect identification of autophagic compartments in conventional transmission electron microscopy of mammalian cells. Autophagy. 2008; 4:257-260. [PubMed: 17986849]

Feng S, Yang Y, Mei Y, Ma L, Zhu DE, Hoti N, Castanares M, Wu M. Cleavage of RIP3 inactivates its caspase-independent apoptosis pathway by removal of kinase domain. Cell Signal. 2007; 19:2056-2067. [PubMed: 17644308]

Feoktistova M, Geserick P, Kellert B, Dimitrova DP, Langlais C, Hupe M, Cain K, MacFarlane M, Hacker G, Leverkus M. cIAPs block Ripoptosome formation, a RIP1/caspase-8 containing intracellular cell death complex differentially regulated by cFLIP isoforms. Mol Cell. 2011; 43:449-463. [PubMed: 21737330]

Festjens N, Vanden Berghe T, Cornelis S, Vandenabeele P. RIP1, a kinase on the crossroads of a cell's decision to live or die. Cell Death Differ. 2007; 14:400-410. [PubMed: 17301840]

Prog Retin Eye Res. Author manuscript; available in PMC 2014 November 01. 
Fischer U, Schulze-Osthoff K. Apoptosis-based therapies and drug targets. Cell Death Differ. 2005; 12(Suppl 1):942-961. [PubMed: 15665817]

Follis AV, Chipuk JE, Fisher JC, Yun MK, Grace CR, Nourse A, Baran K, Ou L, Min L, White SW, Green DR, Kriwacki RW. PUMA binding induces partial unfolding within BCL-xL to disrupt p53 binding and promote apoptosis. Nat Chem Biol. 2013; 9:163-168. [PubMed: 23340338]

Fujita R, Ueda M, Fujiwara K, Ueda H. Prothymosin-alpha plays a defensive role in retinal ischemia through necrosis and apoptosis inhibition. Cell Death Differ. 2009; 16:349-358. [PubMed: 18989338]

Fulda S, Vucic D. Targeting IAP proteins for therapeutic intervention in cancer. Nat Rev Drug Discov. 2012; 11:109-124. [PubMed: 22293567]

Galluzzi L, Kroemer G. Necroptosis: a specialized pathway of programmed necrosis. Cell. 2008; 135:1161-1163. [PubMed: 19109884]

Galluzzi L, Vitale I, Abrams JM, Alnemri ES, Baehrecke EH, Blagosklonny MV, Dawson TM, Dawson VL, El-Deiry WS, Fulda S, Gottlieb E, Green DR, Hengartner MO, Kepp O, Knight RA, Kumar S, Lipton SA, Lu X, Madeo F, Malorni W, Mehlen P, Nunez G, Peter ME, Piacentini M, Rubinsztein DC, Shi Y, Simon HU, Vandenabeele P, White E, Yuan J, Zhivotovsky B, Melino G, Kroemer G. Molecular definitions of cell death subroutines: recommendations of the Nomenclature Committee on Cell Death 2012. Cell Death Differ. 2012; 19:107-120. [PubMed: 21760595]

Gavathiotis E, Reyna DE, Davis ML, Bird GH, Walensky LD. BH3-triggered structural reorganization drives the activation of proapoptotic BAX. Mol Cell. 2010; 40:481-492. [PubMed: 21070973]

Gavathiotis E, Suzuki M, Davis ML, Pitter K, Bird GH, Katz SG, Tu HC, Kim H, Cheng EH, Tjandra N, Walensky LD. BAX activation is initiated at a novel interaction site. Nature. 2008; 455:10761081. [PubMed: 18948948]

Gavrieli Y, Sherman Y, Ben-Sasson SA. Identification of programmed cell death in situ via specific labeling of nuclear DNA fragmentation. J Cell Biol. 1992; 119:493-501. [PubMed: 1400587]

Goossens V, Grooten J, De Vos K, Fiers W. Direct evidence for tumor necrosis factor-induced mitochondrial reactive oxygen intermediates and their involvement in cytotoxicity. Proc Natl Acad Sci U S A. 1995; 92:8115-8119. [PubMed: 7667254]

Grasl-Kraupp B, Ruttkay-Nedecky B, Koudelka H, Bukowska K, Bursch W, Schulte-Hermann R. In situ detection of fragmented DNA (TUNEL assay) fails to discriminate among apoptosis, necrosis, and autolytic cell death: a cautionary note. Hepatology. 1995; 21:1465-1468. [PubMed: 7737654]

Green DR, Oberst A, Dillon CP, Weinlich R, Salvesen GS. RIPK-dependent necrosis and its regulation by caspases: a mystery in five acts. Mol Cell. 2011; 44:9-16. [PubMed: 21981915]

Grimm C, Wenzel A, Hafezi F, Yu S, Redmond TM, Reme CE. Protection of Rpe65-deficient mice identifies rhodopsin as a mediator of light-induced retinal degeneration. Nat Genet. 2000; 25:6366. [PubMed: 10802658]

Gunther C, Martini E, Wittkopf N, Amann K, Weigmann B, Neumann H, Waldner MJ, Hedrick SM, Tenzer S, Neurath MF, Becker C. Caspase-8 regulates TNF-alpha-induced epithelial necroptosis and terminal ileitis. Nature. 2011; 477:335-339. [PubMed: 21921917]

Hahn P, Lindsten T, Lyubarsky A, Ying GS, Pugh EN Jr. Thompson CB, Dunaief JL. Deficiency of Bax and Bak protects photoreceptors from light damage in vivo. Cell Death Differ. 2004; 11:1192-1197. [PubMed: 15272317]

Hara T, Nakamura K, Matsui M, Yamamoto A, Nakahara Y, Suzuki-Migishima R, Yokoyama M, Mishima K, Saito I, Okano H, Mizushima N. Suppression of basal autophagy in neural cells causes neurodegenerative disease in mice. Nature. 2006; 441:885-889. [PubMed: 16625204]

Harder JM, Fernandes KA, Libby RT. The Bcl-2 family member BIM has multiple glaucoma-relevant functions in DBA/2J mice. Sci Rep. 2012; 2:530. [PubMed: 22833783]

Hartong DT, Berson EL, Dryja TP. Retinitis pigmentosa. Lancet. 2006; 368:1795-1809. [PubMed: 17113430]

Hirt UA, Leist M. Rapid, noninflammatory and PS-dependent phagocytic clearance of necrotic cells. Cell Death Differ. 2003; 10:1156-1164. [PubMed: 14502239]

He MX, He YW. A role for c-FLIP(L) in the regulation of apoptosis, autophagy, and necroptosis in T lymphocytes. Cell Death Differ. 2013; 20:188-197. [PubMed: 23175183] 
He S, Liang Y, Shao F, Wang X. Toll-like receptors activate programmed necrosis in macrophages through a receptor-interacting kinase-3-mediated pathway. Proc Natl Acad Sci U S A. 2011; 108:20054-20059. [PubMed: 22123964]

He S, Wang L, Miao L, Wang T, Du F, Zhao L, Wang X. Receptor interacting protein kinase-3 determines cellular necrotic response to TNF-alpha. Cell. 2009; 137:1100-1111. [PubMed: 19524512]

Hisatomi T, Nakazawa T, Noda K, Almulki L, Miyahara S, Nakao S, Ito Y, She H, Kohno R, Michaud N, Ishibashi T, Hafezi-Moghadam A, Badley AD, Kroemer G, Miller JW. HIV protease inhibitors provide neuroprotection through inhibition of mitochondrial apoptosis in mice. J Clin Invest. 2008; 118:2025-2038. [PubMed: 18497877]

Hisatomi T, Sakamoto T, Murata T, Yamanaka I, Oshima Y, Hata Y, Ishibashi T, Inomata H, Susin SA, Kroemer G. Relocalization of apoptosis-inducing factor in photoreceptor apoptosis induced by retinal detachment in vivo. Am J Pathol. 2001; 158:1271-1278. [PubMed: 11290545]

Hisatomi T, Sakamoto T, Sonoda KH, Tsutsumi C, Qiao H, Enaida H, Yamanaka I, Kubota T, Ishibashi T, Kura S, Susin SA, Kroemer G. Clearance of apoptotic photoreceptors: elimination of apoptotic debris into the subretinal space and macrophage-mediated phagocytosis via phosphatidylserine receptor and integrin alphavbeta3. Am J Pathol. 2003; 162:1869-1879. [PubMed: 12759244]

Hitomi J, Christofferson DE, Ng A, Yao J, Degterev A, Xavier RJ, Yuan J. Identification of a molecular signaling network that regulates a cellular necrotic cell death pathway. Cell. 2008; 135:1311-1323. [PubMed: 19109899]

Hoglen NC, Chen LS, Fisher CD, Hirakawa BP, Groess1 T, Contreras PC. Characterization of IDN-6556 (3-[2-(2-tert-butyl-phenylaminooxalyl)-amino]-propionylamino]-4-oxo-5-(2,3 ,5,6tetrafluorophenoxy)-pentanoic acid): a liver-targeted caspase inhibitor. J Pharmacol Exp Ther. 2004; 309:634-640. [PubMed: 14742742]

Holler N, Zaru R, Micheau O, Thome M, Attinger A, Valitutti S, Bodmer JL, Schneider P, Seed B, Tschopp J. Fas triggers an alternative, caspase-8-independent cell death pathway using the kinase RIP as effector molecule. Nat Immunol. 2000; 1:489-495. [PubMed: 11101870]

Hollyfield JG, Bonilha VL, Rayborn ME, Yang X, Shadrach KG, Lu L, Ufret RL, Salomon RG, Perez VL. Oxidative damage-induced inflammation initiates age-related macular degeneration. Nat Med. 2008; 14:194-198. [PubMed: 18223656]

Honarpour N, Gilbert SL, Lahn BT, Wang X, Herz J. Apaf-1 deficiency and neural tube closure defects are found in fog mice. Proc Natl Acad Sci U S A. 2001; 98:9683-9687. [PubMed: 11504943]

Hsu YT, Wolter KG, Youle RJ. Cytosol-to-membrane redistribution of Bax and Bcl-X(L) during apoptosis. Proc Natl Acad Sci U S A. 1997; 94:3668-3672. [PubMed: 9108035]

Huang Y, Park YC, Rich RL, Segal D, Myszka DG, Wu H. Structural basis of caspase inhibition by XIAP: differential roles of the linker versus the BIR domain. Cell. 2001; 104:781-790. [PubMed: 11257231]

Huesmann GR, Clayton DF. Dynamic role of postsynaptic caspase-3 and BIRC4 in zebra finch songresponse habituation. Neuron. 2006; 52:1061-1072. [PubMed: 17178408]

Hyman BT, Yuan J. Apoptotic and non-apoptotic roles of caspases in neuronal physiology and pathophysiology. Nat Rev Neurosci. 2012; 13:395-406. [PubMed: 22595785]

Ichimura Y, Kirisako T, Takao T, Satomi Y, Shimonishi Y, Ishihara N, Mizushima N, Tanida I, Kominami E, Ohsumi M, Noda T, Ohsumi Y. A ubiquitin-like system mediates protein lipidation. Nature. 2000; 408:488-492. [PubMed: 11100732]

Jablonski MM, Tombran-Tink J, Mrazek DA, Iannaccone A. Pigment epithelium-derived factor supports normal development of photoreceptor neurons and opsin expression after retinal pigment epithelium removal. J Neurosci. 2000; 20:7149-7157. [PubMed: 11007870]

Johnson LV, Leitner WP, Rivest AJ, Staples MK, Radeke MJ, Anderson DH. The Alzheimer's A beta -peptide is deposited at sites of complement activation in pathologic deposits associated with aging and age-related macular degeneration. Proc Natl Acad Sci U S A. 2002; 99:11830-11835. [PubMed: 12189211] 
Joly S, Lange C, Thiersch M, Samardzija M, Grimm C. Leukemia inhibitory factor extends the lifespan of injured photoreceptors in vivo. J Neurosci. 2008; 28:13765-13774. [PubMed: 19091967]

Jomary C, Neal MJ, Jones SE. Characterization of cell death pathways in murine retinal neurodegeneration implicates cytochrome $\mathrm{c}$ release, caspase activation, and bid cleavage. Mol Cell Neurosci. 2001; 18:335-346. [PubMed: 11640892]

Jones SE, Jomary C, Grist J, Thomas MR, Neal MJ. Expression of alphaB-crystallin in a mouse model of inherited retinal degeneration. Neuroreport. 1998; 9:4161-4165. [PubMed: 9926867]

Jono H, Lim JH, Chen LF, Xu H, Trompouki E, Pan ZK, Mosialos G, Li JD. NF-kappaB is essential for induction of CYLD, the negative regulator of NF-kappaB: evidence for a novel inducible autoregulatory feedback pathway. J Biol Chem. 2004; 279:36171-36174. [PubMed: 15226292]

Joseph RM, Li T. Overexpression of Bcl-2 or Bcl-XL transgenes and photoreceptor degeneration. Invest Ophthalmol Vis Sci. 1996; 37:2434-2446. [PubMed: 8933760]

Joza N, Oudit GY, Brown D, Benit P, Kassiri Z, Vahsen N, Benoit L, Patel MM, Nowikovsky K, Vassault A, Backx PH, Wada T, Kroemer G, Rustin P, Penninger JM. Muscle-specific loss of apoptosis-inducing factor leads to mitochondrial dysfunction, skeletal muscle atrophy, and dilated cardiomyopathy. Mol Cell Biol. 2005; 25:10261-10272. [PubMed: 16287843]

Joza N, Susin SA, Daugas E, Stanford WL, Cho SK, Li CY, Sasaki T, Elia AJ, Cheng HY, Ravagnan L, Ferri KF, Zamzami N, Wakeham A, Hakem R, Yoshida H, Kong YY, Mak TW, ZunigaPflucker JC, Kroemer G, Penninger JM. Essential role of the mitochondrial apoptosis-inducing factor in programmed cell death. Nature. 2001; 410:549-554. [PubMed: 11279485]

Jung YS, Kim HY, Lee YJ, Kim E. Subcellular localization of Daxx determines its opposing functions in ischemic cell death. FEBS Lett. 2007; 581:843-852. [PubMed: 17289031]

Jurgens B, Hainz U, Fuchs D, Felzmann T, Heitger A. Interferon-gamma-triggered indoleamine 2,3dioxygenase competence in human monocyte-derived dendritic cells induces regulatory activity in allogeneic T cells. Blood. 2009; 114:3235-3243. [PubMed: 19625705]

Kaiser WJ, Upton JW, Long AB, Livingston-Rosanoff D, Daley-Bauer LP, Hakem R, Caspary T, Mocarski ES. RIP3 mediates the embryonic lethality of caspase-8-deficient mice. Nature. 2011; 471:368-372. [PubMed: 21368762]

Kaneko H, Dridi S, Tarallo V, Gelfand BD, Fowler BJ, Cho WG, Kleinman ME, Ponicsan SL, Hauswirth WW, Chiodo VA, Kariko K, Yoo JW, Lee DK, Hadziahmetovic M, Song Y, Misra S, Chaudhuri G, Buaas FW, Braun RE, Hinton DR, Zhang Q, Grossniklaus HE, Provis JM, Madigan MC, Milam AH, Justice NL, Albuquerque RJ, Blandford AD, Bogdanovich S, Hirano Y, Witta J, Fuchs E, Littman DR, Ambati BK, Rudin CM, Chong MM, Provost P, Kugel JF, Goodrich JA, Dunaief JL, Baffi JZ, Ambati J. DICER1 deficit induces Alu RNA toxicity in agerelated macular degeneration. Nature. 2011; 471:325-330. [PubMed: 21297615]

Kang TB, Ben-Moshe T, Varfolomeev EE, Pewzner-Jung Y, Yogev N, Jurewicz A, Waisman A, Brenner O, Haffner R, Gustafsson E, Ramakrishnan P, Lapidot T, Wallach D. Caspase-8 serves both apoptotic and nonapoptotic roles. J Immunol. 2004; 173:2976-2984. [PubMed: 15322156]

Katayama M, Kawaguchi T, Berger MS, Pieper RO. DNA damaging agent-induced autophagy produces a cytoprotective adenosine triphosphate surge in malignant glioma cells. Cell Death Differ. 2007; 14:548-558. [PubMed: 16946731]

Kayama M, Nakazawa T, Thanos A, Morizane Y, Murakami Y, Theodoropoulou S, Abe T, Vavvas D, Miller JW. Heat shock protein 70 (HSP70) is critical for the photoreceptor stress response after retinal detachment via modulating anti-apoptotic Akt kinase. Am J Pathol. 2011; 178:1080-1091. [PubMed: 21356360]

Kelliher MA, Grimm S, Ishida Y, Kuo F, Stanger BZ, Leder P. The death domain kinase RIP mediates the TNF-induced NF-kappaB signal. Immunity. 1998; 8:297-303. [PubMed: 9529147]

Kerr JF, Wyllie AH, Currie AR. Apoptosis: a basic biological phenomenon with wide-ranging implications in tissue kinetics. Br J Cancer. 1972; 26:239-257. [PubMed: 4561027]

Khakh BS, North RA. P2X receptors as cell-surface ATP sensors in health and disease. Nature. 2006; 442:527-532. [PubMed: 16885977]

Prog Retin Eye Res. Author manuscript; available in PMC 2014 November 01. 
Kigerl KA, Gensel JC, Ankeny DP, Alexander JK, Donnelly DJ, Popovich PG. Identification of two distinct macrophage subsets with divergent effects causing either neurotoxicity or regeneration in the injured mouse spinal cord. J Neurosci. 2009; 29:13435-13444. [PubMed: 19864556]

Kim YS, Morgan MJ, Choksi S, Liu ZG. TNF-induced activation of the Nox1 NADPH oxidase and its role in the induction of necrotic cell death. Mol Cell. 2007; 26:675-687. [PubMed: 17560373]

Kirisako T, Ichimura Y, Okada H, Kabeya Y, Mizushima N, Yoshimori T, Ohsumi M, Takao T, Noda T, Ohsumi Y. The reversible modification regulates the membrane-binding state of Apg8/Aut7 essential for autophagy and the cytoplasm to vacuole targeting pathway. J Cell Biol. 2000; 151:263-276. [PubMed: 11038174]

Klein JA, Longo-Guess CM, Rossmann MP, Seburn KL, Hurd RE, Frankel WN, Bronson RT, Ackerman SL. The harlequin mouse mutation downregulates apoptosis-inducing factor. Nature. 2002; 419:367-374. [PubMed: 12353028]

Knight ZA, Gonzalez B, Feldman ME, Zunder ER, Goldenberg DD, Williams O, Loewith R, Stokoe D, Balla A, Toth B, Balla T, Weiss WA, Williams RL, Shokat KM. A pharmacological map of the PI3-K family defines a role for p110alpha in insulin signaling. Cell. 2006; 125:733-747. [PubMed: 16647110]

Komatsu M, Waguri S, Chiba T, Murata S, Iwata J, Tanida I, Ueno T, Koike M, Uchiyama Y, Kominami E, Tanaka K. Loss of autophagy in the central nervous system causes neurodegeneration in mice. Nature. 2006; 441:880-884. [PubMed: 16625205]

Komatsu M, Waguri S, Ueno T, Iwata J, Murata S, Tanida I, Ezaki J, Mizushima N, Ohsumi Y, Uchiyama Y, Kominami E, Tanaka K, Chiba T. Impairment of starvation-induced and constitutive autophagy in Atg7-deficient mice. J Cell Biol. 2005; 169:425-434. [PubMed: 15866887]

Krantic S, Mechawar N, Reix S, Quirion R. Apoptosis-inducing factor: a matter of neuron life and death. Prog Neurobiol. 2007; 81:179-196. [PubMed: 17267093]

Krikos A, Laherty CD, Dixit VM. Transcriptional activation of the tumor necrosis factor alphainducible zinc finger protein, A20, is mediated by kappa B elements. J Biol Chem. 1992; 267:17971-17976. [PubMed: 1381359]

Kroemer G, Galluzzi L, Vandenabeele P, Abrams J, Alnemri ES, Baehrecke EH, Blagosklonny MV, El-Deiry WS, Golstein P, Green DR, Hengartner M, Knight RA, Kumar S, Lipton SA, Malorni W, Nunez G, Peter ME, Tschopp J, Yuan J, Piacentini M, Zhivotovsky B, Melino G. Classification of cell death: recommendations of the Nomenclature Committee on Cell Death 2009. Cell Death Differ. 2009; 16:3-11. [PubMed: 18846107]

Kroemer G, Levine B. Autophagic cell death: the story of a misnomer. Nat Rev Mol Cell Biol. 2008; 9:1004-1010. [PubMed: 18971948]

Krysko O, De Ridder L, Cornelissen M. Phosphatidylserine exposure during early primary necrosis (oncosis) in JB6 cells as evidenced by immunogold labeling technique. Apoptosis. 2004; 9:495500. [PubMed: 15192332]

Kuida K, Haydar TF, Kuan CY, Gu Y, Taya C, Karasuyama H, Su MS, Rakic P, Flavell RA. Reduced apoptosis and cytochrome c-mediated caspase activation in mice lacking caspase 9. Cell. 1998; 94:325-337. [PubMed: 9708735]

Kuida K, Lippke JA, Ku G, Harding MW, Livingston DJ, Su MS, Flavell RA. Altered cytokine export and apoptosis in mice deficient in interleukin-1 beta converting enzyme. Science. 1995; 267:2000-2003. [PubMed: 7535475]

Kunchithapautham K, Rohrer B. Apoptosis and autophagy in photoreceptors exposed to oxidative stress. Autophagy. 2007; 3:433-441. [PubMed: 17471016]

Kuo CT, Zhu S, Younger S, Jan LY, Jan YN. Identification of E2/E3 ubiquitinating enzymes and caspase activity regulating Drosophila sensory neuron dendrite pruning. Neuron. 2006; 51:283290. [PubMed: 16880123]

Lakhani SA, Masud A, Kuida K, Porter GA Jr. Booth CJ, Mehal WZ, Inayat I, Flavell RA. Caspases 3 and 7: key mediators of mitochondrial events of apoptosis. Science. 2006; 311:847-851. [PubMed: 16469926]

Laster SM, Wood JG, Gooding LR. Tumor necrosis factor can induce both apoptic and necrotic forms of cell lysis. J Immunol. 1988; 141:2629-2634. [PubMed: 3171180]

Prog Retin Eye Res. Author manuscript; available in PMC 2014 November 01. 
Lee YS, Dayma Y, Park MY, Kim KI, Yoo SE, Kim E. Daxx is a key downstream component of receptor interacting protein kinase 3 mediating retinal ischemic cell death. FEBS Lett. 2013; 587:266-271. [PubMed: 23260419]

Lei K, Davis RJ. JNK phosphorylation of Bim-related members of the Bcl2 family induces Baxdependent apoptosis. Proc Natl Acad Sci U S A. 2003; 100:2432-2437. [PubMed: 12591950]

Leonard JR, Klocke BJ, D'Sa C, Flavell RA, Roth KA. Strain-dependent neurodevelopmental abnormalities in caspase-3-deficient mice. J Neuropathol Exp Neurol. 2002; 61:673-677. [PubMed: 12152782]

Lettre G, Hengartner MO. Developmental apoptosis in C. elegans: a complex CEDnario. Nat Rev Mol Cell Biol. 2006; 7:97-108. [PubMed: 16493416]

Lewis GP, Guerin CJ, Anderson DH, Matsumoto B, Fisher SK. Rapid changes in the expression of glial cell proteins caused by experimental retinal detachment. Am J Ophthalmol. 1994; 118:368376. [PubMed: 7916177]

Li H, Zhu H, Xu CJ, Yuan J. Cleavage of BID by caspase 8 mediates the mitochondrial damage in the Fas pathway of apoptosis. Cell. 1998; 94:491-501. [PubMed: 9727492]

Li J, Yuan J. Caspases in apoptosis and beyond. Oncogene. 2008; 27:6194-6206. [PubMed: 18931687]

Li P, Allen H, Banerjee S, Franklin S, Herzog L, Johnston C, McDowell J, Paskind M, Rodman L, Salfeld J, et al. Mice deficient in IL-1 beta-converting enzyme are defective in production of mature IL-1 beta and resistant to endotoxic shock. Cell. 1995; 80:401-411. [PubMed: 7859282]

Li P, Nijhawan D, Budihardjo I, Srinivasula SM, Ahmad M, Alnemri ES, Wang X. Cytochrome c and dATP-dependent formation of Apaf-1/caspase-9 complex initiates an apoptotic protease cascade. Cell. 1997; 91:479-489. [PubMed: 9390557]

Li Q, Li G, Lan X, Zheng M, Chen KH, Cao CM, Xiao RP. Receptor interacting protein 3 suppresses vascular smooth muscle cell growth by inhibition of the phosphoinositide 3-kinase-Akt axis. J Biol Chem. 2010a; 285:9535-9544. [PubMed: 20042608]

Li Y, Johnson N, Capano M, Edwards M, Crompton M. Cyclophilin-D promotes the mitochondrial permeability transition but has opposite effects on apoptosis and necrosis. Biochem J. 2004; 383:101-109. [PubMed: 15233627]

Li Z, Jo J, Jia JM, Lo SC, Whitcomb DJ, Jiao S, Cho K, Sheng M. Caspase-3 activation via mitochondria is required for long-term depression and AMPA receptor internalization. Cell. 2010b; 141:859-871. [PubMed: 20510932]

Lin J, Li H, Yang M, Ren J, Huang Z, Han F, Huang J, Ma J, Zhang D, Zhang Z, Wu J, Huang D, Qiao M, Jin G, Wu Q, Huang Y, Du J, Han J. A role of RIP3-mediated macrophage necrosis in atherosclerosis development. Cell Rep. 2013; 3:200-210. [PubMed: 23333278]

Lin Y, Devin A, Rodriguez Y, Liu ZG. Cleavage of the death domain kinase RIP by caspase-8 prompts TNF-induced apoptosis. Genes Dev. 1999; 13:2514-2526. [PubMed: 10521396]

Lin Y, Ma W, Benchimol S. Pidd, a new death-domain-containing protein, is induced by p53 and promotes apoptosis. Nat Genet. 2000; 26:122-127. [PubMed: 10973264]

Linkermann A, Brasen JH, Himmerkus N, Liu S, Huber TB, Kunzendorf U, Krautwald S. Rip1 (receptor-interacting protein kinase 1) mediates necroptosis and contributes to renal ischemia/ reperfusion injury. Kidney Int. 2012; 81:751-761. [PubMed: 22237751]

Linton SD. Caspase inhibitors: a pharmaceutical industry perspective. Curr Top Med Chem. 2005; 5:1697-1717. [PubMed: 16375749]

Lockshin RA. Programmed cell death. Activation of lysis by a mechanism involving the synthesis of protein. J Insect Physiol. 1969; 15:1505-1516. [PubMed: 5348113]

Lockshin RA, Williams CM. Programmed Cell Death--I. Cytology of Degeneration in the Intersegmental Muscles of the Pernyi Silkmoth. J Insect Physiol. 1965; 11:123-133. [PubMed: 14287218]

Lotze MT, Tracey KJ. High-mobility group box 1 protein (HMGB1): nuclear weapon in the immune arsenal. Nat Rev Immunol. 2005; 5:331-342. [PubMed: 15803152]

Lovell JF, Billen LP, Bindner S, Shamas-Din A, Fradin C, Leber B, Andrews DW. Membrane binding by tBid initiates an ordered series of events culminating in membrane permeabilization by Bax. Cell. 2008; 135:1074-1084. [PubMed: 19062087] 
Lukens JR, Vogel P, Johnson GR, Kelliher MA, Iwakura Y, Lamkanfi M, Kanneganti TD. RIP1driven autoinflammation targets IL-1alpha independently of inflammasomes and RIP3. Nature. 2013; 498:224-227. [PubMed: 23708968]

Luo X, Budihardjo I, Zou H, Slaughter C, Wang X. Bid, a Bcl2 interacting protein, mediates cytochrome $\mathrm{c}$ release from mitochondria in response to activation of cell surface death receptors. Cell. 1998; 94:481-490. [PubMed: 9727491]

Machemer R, Norton EW. Experimental retinal detachment in the owl monkey. I. Methods of producation and clinical picture. Am J Ophthalmol. 1968; 66:388-396. [PubMed: 4970985]

Mahoney DJ, Cheung HH, Mrad RL, Plenchette S, Simard C, Enwere E, Arora V, Mak TW, Lacasse EC, Waring J, Korneluk RG. Both cIAP1 and cIAP2 regulate TNFalpha-mediated NF-kappaB activation. Proc Natl Acad Sci U S A. 2008; 105:11778-11783. [PubMed: 18697935]

Makman MH, Dvorkin B, White A. Evidence for induction by cortisol in vitro of a protein inhibitor of transport and phosphorylation processes in rat thymocytes. Proc Natl Acad Sci U S A. 1971; 68:1269-1273. [PubMed: 5288374]

Mancias JD, Kimmelman AC. Targeting autophagy addiction in cancer. Oncotarget. 2011; 2:13021306. [PubMed: 22185891]

Marino G, Fernandez AF, Cabrera S, Lundberg YW, Cabanillas R, Rodriguez F, Salvador-Montoliu N, Vega JA, Germana A, Fueyo A, Freije JM, Lopez-Otin C. Autophagy is essential for mouse sense of balance. J Clin Invest. 2010; 120:2331-2344. [PubMed: 20577052]

Marino G, Salvador-Montoliu N, Fueyo A, Knecht E, Mizushima N, Lopez-Otin C. Tissue-specific autophagy alterations and increased tumorigenesis in mice deficient in Atg4C/autophagin-3. J Biol Chem. 2007; 282:18573-18583. [PubMed: 17442669]

Marzo I, Brenner C, Zamzami N, Jurgensmeier JM, Susin SA, Vieira HL, Prevost MC, Xie Z, Matsuyama S, Reed JC, Kroemer G. Bax and adenine nucleotide translocator cooperate in the mitochondrial control of apoptosis. Science. 1998; 281:2027-2031. [PubMed: 9748162]

McKernan DP, Cotter TG. A Critical role for Bim in retinal ganglion cell death. J Neurochem. 2007; 102:922-930. [PubMed: 17442051]

Meylan E, Burns K, Hofmann K, Blancheteau V, Martinon F, Kelliher M, Tschopp J. RIP1 is an essential mediator of Toll-like receptor 3-induced NF-kappa B activation. Nat Immunol. 2004; 5:503-507. [PubMed: 15064760]

Micheau O, Lens S, Gaide O, Alevizopoulos K, Tschopp J. NF-kappaB signals induce the expression of c-FLIP. Mol Cell Biol. 2001; 21:5299-5305. [PubMed: 11463813]

Micheau O, Thome M, Schneider P, Holler N, Tschopp J, Nicholson DW, Briand C, Grutter MG. The long form of FLIP is an activator of caspase- 8 at the Fas death-inducing signaling complex. $\mathrm{J}$ Biol Chem. 2002; 277:45162-45171. [PubMed: 12215447]

Micheau O, Tschopp J. Induction of TNF receptor I-mediated apoptosis via two sequential signaling complexes. Cell. 2003; 114:181-190. [PubMed: 12887920]

Midorikawa R, Yamamoto-Hino M, Awano W, Hinohara Y, Suzuki E, Ueda R, Goto S. Autophagydependent rhodopsin degradation prevents retinal degeneration in Drosophila. J Neurosci. 2010; 30:10703-10719. [PubMed: 20702701]

Miura M, Zhu H, Rotello R, Hartwieg EA, Yuan J. Induction of apoptosis in fibroblasts by IL-1 betaconverting enzyme, a mammalian homolog of the C. elegans cell death gene ced-3. Cell. 1993; 75:653-660. [PubMed: 8242741]

Miyanishi M, Tada K, Koike M, Uchiyama Y, Kitamura T, Nagata S. Identification of Tim4 as a phosphatidylserine receptor. Nature. 2007; 450:435-439. [PubMed: 17960135]

Mizukoshi S, Nakazawa M, Sato K, Ozaki T, Metoki T, Ishiguro S. Activation of mitochondrial calpain and release of apoptosis-inducing factor from mitochondria in RCS rat retinal degeneration. Exp Eye Res. 2010; 91:353-361. [PubMed: 20547152]

Mizushima N, Levine B. Autophagy in mammalian development and differentiation. Nat Cell Biol. 2010; 12:823-830. [PubMed: 20811354]

Mizushima N, Levine B, Cuervo AM, Klionsky DJ. Autophagy fights disease through cellular selfdigestion. Nature. 2008; 451:1069-1075. [PubMed: 18305538]

Prog Retin Eye Res. Author manuscript; available in PMC 2014 November 01. 
Mizushima N, Noda T, Yoshimori T, Tanaka Y, Ishii T, George MD, Klionsky DJ, Ohsumi M, Ohsumi Y. A protein conjugation system essential for autophagy. Nature. 1998; 395:395-398. [PubMed: 9759731]

Mizushima N, Yoshimori T, Levine B. Methods in mammalian autophagy research. Cell. 2010; 140:313-326. [PubMed: 20144757]

Modjtahedi N, Giordanetto F, Madeo F, Kroemer G. Apoptosis-inducing factor: vital and lethal. Trends Cell Biol. 2006; 16:264-272. [PubMed: 16621561]

Morgan MJ, Kim YS, Liu ZG. Membrane-bound Fas ligand requires RIP1 for efficient activation of caspase-8 within the death-inducing signaling complex. J Immunol. 2009; 183:3278-3284. [PubMed: 19641134]

Mosinger Ogilvie J, Deckwerth TL, Knudson CM, Korsmeyer SJ. Suppression of developmental retinal cell death but not of photoreceptor degeneration in Bax-deficient mice. Invest Ophthalmol Vis Sci. 1998; 39:1713-1720. [PubMed: 9699561]

Moubarak RS, Yuste VJ, Artus C, Bouharrour A, Greer PA, Menissier-de Murcia J, Susin SA. Sequential activation of poly(ADP-ribose) polymerase 1, calpains, and Bax is essential in apoptosis-inducing factor-mediated programmed necrosis. Mol Cell Biol. 2007; 27:4844-4862. [PubMed: 17470554]

Moulin M, Anderton H, Voss AK, Thomas T, Wong WW, Bankovacki A, Feltham R, Chau D, Cook WD, Silke J, Vaux DL. IAPs limit activation of RIP kinases by TNF receptor 1 during development. Embo J. 2012; 31:1679-1691. [PubMed: 22327219]

Murakami Y, Ikeda Y, Yonemitsu Y, Onimaru M, Nakagawa K, Kohno R, Miyazaki M, Hisatomi T, Nakamura M, Yabe T, Hasegawa M, Ishibashi T, Sueishi K. Inhibition of nuclear translocation of apoptosis-inducing factor is an essential mechanism of the neuroprotective activity of pigment epithelium-derived factor in a rat model of retinal degeneration. Am J Pathol. 2008; 173:13261338. [PubMed: 18845835]

Murakami Y, Ikeda Y, Yoshida N, Notomi S, Hisatomi T, Oka S, De Luca G, Yonemitsu Y, Bignami M, Nakabeppu Y, Ishibashi T. MutT homolog-1 attenuates oxidative DNA damage and delays photoreceptor cell death in inherited retinal degeneration. Am J Pathol. 2012a; 181:1378-1386. [PubMed: 22841817]

Murakami Y, Matsumoto H, Roh M, Giani A, Kataoka K, Morizane Y, Kayama M, Thanos A, Nakatake S, Notomi S, Hisatomi T, Ikeda Y, Ishibashi T, Connor KM, Miller JW, Vavvas DG. Programmed necrosis, not apoptosis, is a key mediator of cell loss and DAMP-mediated inflammation in dsRNA-induced retinal degeneration. Cell Death Differ. 2013 in press.

Murakami Y, Matsumoto H, Roh M, Suzuki J, Hisatomi T, Ikeda Y, Miller JW, Vavvas DG. Receptor interacting protein kinase mediates necrotic cone but not rod cell death in a mouse model of inherited degeneration. Proc Natl Acad Sci U S A. 2012b; 109:14598-14603. [PubMed: 22908283]

Nagata S, Hanayama R, Kawane K. Autoimmunity and the clearance of dead cells. Cell. 2010; 140:619-630. [PubMed: 20211132]

Nakagawa T, Shimizu S, Watanabe T, Yamaguchi O, Otsu K, Yamagata H, Inohara H, Kubo T, Tsujimoto Y. Cyclophilin D-dependent mitochondrial permeability transition regulates some necrotic but not apoptotic cell death. Nature. 2005; 434:652-658. [PubMed: 15800626]

Nakai A, Yamaguchi O, Takeda T, Higuchi Y, Hikoso S, Taniike M, Omiya S, Mizote I, Matsumura Y, Asahi M, Nishida K, Hori M, Mizushima N, Otsu K. The role of autophagy in cardiomyocytes in the basal state and in response to hemodynamic stress. Nat Med. 2007; 13:619-624. [PubMed: 17450150]

Nakata K, Crabb JW, Hollyfield JG. Crystallin distribution in Bruch's membrane-choroid complex from AMD and age-matched donor eyes. Exp Eye Res. 2005; 80:821-826. [PubMed: 15939038]

Nakazawa T, Hisatomi T, Nakazawa C, Noda K, Maruyama K, She H, Matsubara A, Miyahara S, Nakao S, Yin Y, Benowitz L, Hafezi-Moghadam A, Miller JW. Monocyte chemoattractant protein 1 mediates retinal detachment-induced photoreceptor apoptosis. Proc Natl Acad Sci U S A. 2007; 104:2425-2430. [PubMed: 17284607]

Prog Retin Eye Res. Author manuscript; available in PMC 2014 November 01. 
Nakazawa T, Kayama M, Ryu M, Kunikata H, Watanabe R, Yasuda M, Kinugawa J, Vavvas D, Miller JW. Tumor necrosis factor-alpha mediates photoreceptor death in a rodent model of retinal detachment. Invest Ophthalmol Vis Sci. 2011; 52:1384-1391. [PubMed: 21402953]

Nakazawa T, Matsubara A, Noda K, Hisatomi T, She H, Skondra D, Miyahara S, Sobrin L, Thomas KL, Chen DF, Grosskreutz CL, Hafezi-Moghadam A, Miller JW. Characterization of cytokine responses to retinal detachment in rats. Mol Vis. 2006; 12:867-878. [PubMed: 16917487]

Nathan C, Ding A. Nonresolving inflammation. Cell. 2010; 140:871-882. [PubMed: 20303877]

Portera-Cailliau C, Sung CH, Nathans J, Adler R. Apoptotic photoreceptor cell death in mouse models of retinitis pigmentosa. Proc Natl Acad Sci U S A. 1994; 91:974-978. [PubMed: 8302876]

Newton K, Sun X, Dixit VM. Kinase RIP3 is dispensable for normal NF-kappa Bs, signaling by the Bcell and T-cell receptors, tumor necrosis factor receptor 1, and Toll-like receptors 2 and 4 . Mol Cell Biol. 2004; 24:1464-1469. [PubMed: 14749364]

Norberg E, Gogvadze V, Vakifahmetoglu H, Orrenius S, Zhivotovsky B. Oxidative modification sensitizes mitochondrial apoptosis-inducing factor to calpain-mediated processing. Free Radic Biol Med. 2010; 48:791-797. [PubMed: 20043986]

Notomi S, Hisatomi T, Kanemaru T, Takeda A, Ikeda Y, Enaida H, Kroemer G, Ishibashi T. Critical involvement of extracellular ATP acting on P2RX7 purinergic receptors in photoreceptor cell death. Am J Pathol. 2011; 179:2798-2809. [PubMed: 21983632]

Notomi S, Hisatomi T, Murakami Y, Terasaki H, Sonoda S, Asato R, Takeda A, Ikeda Y, Enaida H, Sakamoto T, Ishibashi T. Dynamic Increase in Extracellular ATP Accelerates Photoreceptor Cell Apoptosis via Ligation of P2RX7 in Subretinal Hemorrhage. PLoS One. 2013; 8:e53338. [PubMed: 23308196]

O’Donnell MA, Perez-Jimenez E, Oberst A, Ng A, Massoumi R, Xavier R, Green DR, Ting AT. Caspase 8 inhibits programmed necrosis by processing CYLD. Nat Cell Biol. 2011; 13:14371442. [PubMed: 22037414]

Oberst A, Dillon CP, Weinlich R, McCormick LL, Fitzgerald P, Pop C, Hakem R, Salvesen GS, Green DR. Catalytic activity of the caspase-8-FLIP(L) complex inhibits RIPK3-dependent necrosis. Nature. 2011; 471:363-367. [PubMed: 21368763]

Ohsumi Y. Molecular dissection of autophagy: two ubiquitin-like systems. Nat Rev Mol Cell Biol. 2001; 2:211-216. [PubMed: 11265251]

Otera H, Ohsakaya S, Nagaura Z, Ishihara N, Mihara K. Export of mitochondrial AIF in response to proapoptotic stimuli depends on processing at the intermembrane space. Embo J. 2005; 24:13751386. [PubMed: 15775970]

Ozaki T, Nakazawa M, Yamashita T, Sorimachi H, Hata S, Tomita H, Isago H, Baba A, Ishiguro S. Intravitreal injection or topical eye-drop application of a mu-calpain $\mathrm{C} 2 \mathrm{~L}$ domain peptide protects against photoreceptor cell death in Royal College of Surgeons' rats, a model of retinitis pigmentosa. Biochim Biophys Acta. 2012; 1822:1783-1795. [PubMed: 22885154]

Paquet-Durand F, Silva J, Talukdar T, Johnson LE, Azadi S, van Veen T, Ueffing M, Hauck SM, Ekstrom PA. Excessive activation of poly(ADP-ribose) polymerase contributes to inherited photoreceptor degeneration in the retinal degeneration 1 mouse. J Neurosci. 2007; 27:1031110319. [PubMed: 17881537]

Perche O, Doly M, Ranchon-Cole I. Caspase-dependent apoptosis in light-induced retinal degeneration. Invest Ophthalmol Vis Sci. 2007; 48:2753-2759. [PubMed: 17525209]

Peter ME, Krammer PH. The CD95(APO-1/Fas) DISC and beyond. Cell Death Differ. 2003; 10:2635. [PubMed: 12655293]

Pickford F, Masliah E, Britschgi M, Lucin K, Narasimhan R, Jaeger PA, Small S, Spencer B, Rockenstein E, Levine B, Wyss-Coray T. The autophagy-related protein beclin 1 shows reduced expression in early Alzheimer disease and regulates amyloid beta accumulation in mice. J Clin Invest. 2008; 118:2190-2199. [PubMed: 18497889]

Polster BM, Basanez G, Etxebarria A, Hardwick JM, Nicholls DG. Calpain I induces cleavage and release of apoptosis-inducing factor from isolated mitochondria. J Biol Chem. 2005; 280:64476454. [PubMed: 15590628]

Punzo C, Kornacker K, Cepko CL. Stimulation of the insulin/mTOR pathway delays cone death in a mouse model of retinitis pigmentosa. Nat Neurosci. 2009; 12:44-52. [PubMed: 19060896] 
Puthalakath H, Huang DC, O'Reilly LA, King SM, Strasser A. The proapoptotic activity of the Bcl-2 family member Bim is regulated by interaction with the dynein motor complex. Mol Cell. 1999; 3:287-296. [PubMed: 10198631]

Puthalakath H, O'Reilly LA, Gunn P, Lee L, Kelly PN, Huntington ND, Hughes PD, Michalak EM, McKimm-Breschkin J, Motoyama N, Gotoh T, Akira S, Bouillet P, Strasser A. ER stress triggers apoptosis by activating BH3-only protein Bim. Cell. 2007; 129:1337-1349. [PubMed: 17604722]

Puthalakath H, Villunger A, O'Reilly LA, Beaumont JG, Coultas L, Cheney RE, Huang DC, Strasser A. Bmf: a proapoptotic BH3-only protein regulated by interaction with the myosin $\mathrm{V}$ actin motor complex, activated by anoikis. Science. 2001; 293:1829-1832. [PubMed: 11546872]

Qiao H, Sonoda KH, Ikeda Y, Yoshimura T, Hijioka K, Jo YJ, Sassa Y, Tsutsumi-Miyahara C, Hata Y, Akira S, Ishibashi T. Interleukin-18 regulates pathological intraocular neovascularization. J Leukoc Biol. 2007; 81:1012-1021. [PubMed: 17234681]

Qin H, Yeh WI, De Sarno P, Holdbrooks AT, Liu Y, Muldowney MT, Reynolds SL, Yanagisawa LL, Fox TH 3rd, Park K, Harrington LE, Raman C, Benveniste EN. Signal transducer and activator of transcription-3/suppressor of cytokine signaling-3 (STAT3/SOCS3) axis in myeloid cells regulates neuroinflammation. Proc Natl Acad Sci U S A. 2012; 109:5004-5009. [PubMed: 22411837]

Rattner A, Nathans J. The genomic response to retinal disease and injury: evidence for endothelin signaling from photoreceptors to glia. J Neurosci. 2005; 25:4540-4549. [PubMed: 15872101]

Ravagnan L, Gurbuxani S, Susin SA, Maisse C, Daugas E, Zamzami N, Mak T, Jaattela M, Penninger JM, Garrido C, Kroemer G. Heat-shock protein 70 antagonizes apoptosis-inducing factor. Nat Cell Biol. 2001; 3:839-843. [PubMed: 11533664]

Ravichandran KS. Beginnings of a good apoptotic meal: the find-me and eat-me signaling pathways. Immunity. 2011; 35:445-455. [PubMed: 22035837]

Ravikumar B, Berger Z, Vacher C, O’Kane CJ, Rubinsztein DC. Rapamycin pre-treatment protects against apoptosis. Human molecular genetics. 2006; 15:1209-1216. [PubMed: 16497721]

Ravikumar B, Duden R, Rubinsztein DC. Aggregate-prone proteins with polyglutamine and polyalanine expansions are degraded by autophagy. Human molecular genetics. 2002; 11:11071117. [PubMed: 11978769]

Read R, Savelieva K, Baker K, Hansen G, Vogel P. Histopathological and neurological features of Atg4b knockout mice. Veterinary pathology. 2011; 48:486-494. [PubMed: 20634410]

Reimertz C, Kogel D, Rami A, Chittenden T, Prehn JH. Gene expression during ER stress-induced apoptosis in neurons: induction of the BH3-only protein Bbc3/PUMA and activation of the mitochondrial apoptosis pathway. J Cell Biol. 2003; 162:587-597. [PubMed: 12913114]

Reme CE. Autography in visual cells and pigment epithelium. Invest Ophthalmol Vis Sci. 1977; 16:807-814. [PubMed: 302253]

Reme CE, Grimm C, Hafezi F, Marti A, Wenzel A. Apoptotic cell death in retinal degenerations. Prog Retin Eye Res. 1998; 17:443-464. [PubMed: 9777646]

Reme CE, Knop M. Autophagy in frog visual cells in vitro. Invest Ophthalmol Vis Sci. 1980; 19:439_ 456. [PubMed: 6966276]

Reme CE, Wolfrum U, Imsand C, Hafezi F, Williams TP. Photoreceptor autophagy: effects of light history on number and opsin content of degradative vacuoles. Invest Ophthalmol Vis Sci. 1999; 40:2398-2404. [PubMed: 10476808]

Reme CE, Young RW. The effects of hibernation on cone visual cells in the ground squirrel. Invest Ophthalmol Vis Sci. 1977; 16:815-840. [PubMed: 893032]

Ricker LJ, Kijlstra A, de Jager W, Liem AT, Hendrikse F, La Heij EC. Chemokine levels in subretinal fluid obtained during scleral buckling surgery after rhegmatogenous retinal detachment. Invest Ophthalmol Vis Sci. 2010; 51:4143-4150. [PubMed: 20335622]

Riedl SJ, Renatus M, Schwarzenbacher R, Zhou Q, Sun C, Fesik SW, Liddington RC, Salvesen GS. Structural basis for the inhibition of caspase-3 by XIAP. Cell. 2001; 104:791-800. [PubMed: 11257232]

Rosenbaum DM, Degterev A, David J, Rosenbaum PS, Roth S, Grotta JC, Cuny GD, Yuan J, Savitz SI. Necroptosis, a novel form of caspase-independent cell death, contributes to neuronal damage

Prog Retin Eye Res. Author manuscript; available in PMC 2014 November 01. 
in a retinal ischemia-reperfusion injury model. J Neurosci Res. 2010; 88:1569-1576. [PubMed: 20025059]

Roychowdhury S, McMullen MR, Pisano SG, Liu X, Nagy LE. Absence of receptor interacting protein kinase 3 prevents ethanol-induced liver injury. Hepatology. 2012

Sacca F, Marsili A, Quarantelli M, Brescia Morra V, Brunetti A, Carbone R, Pane C, Puorro G, Russo CV, Salvatore E, Tucci T, De Michele G, Filla A. A randomized clinical trial of lithium in multiple system atrophy. Journal of neurology. 2013; 260:458-461. [PubMed: 22932748]

Sanges D, Comitato A, Tammaro R, Marigo V. Apoptosis in retinal degeneration involves crosstalk between apoptosis-inducing factor (AIF) and caspase-12 and is blocked by calpain inhibitors. Proc Natl Acad Sci U S A. 2006; 103:17366-17371. [PubMed: 17088543]

Sarkar S, Floto RA, Berger Z, Imarisio S, Cordenier A, Pasco M, Cook LJ, Rubinsztein DC. Lithium induces autophagy by inhibiting inositol monophosphatase. J Cell Biol. 2005; 170:1101-1111. [PubMed: 16186256]

Saunders JW Jr. Death in embryonic systems. Science. 1966; 154:604-612. [PubMed: 5332319]

Scaffidi C, Schmitz I, Krammer PH, Peter ME. The role of c-FLIP in modulation of CD95-induced apoptosis. J Biol Chem. 1999; 274:1541-1548. [PubMed: 9880531]

Scaffidi P, Misteli T, Bianchi ME. Release of chromatin protein HMGB1 by necrotic cells triggers inflammation. Nature. 2002; 418:191-195. [PubMed: 12110890]

Schocket LS, Witkin AJ, Fujimoto JG, Ko TH, Schuman JS, Rogers AH, Baumal C, Reichel E, Duker JS. Ultrahigh-resolution optical coherence tomography in patients with decreased visual acuity after retinal detachment repair. Ophthalmology. 2006; 113:666-672. [PubMed: 16581427]

Schotte P, Declercq W, Van Huffel S, Vandenabeele P, Beyaert R. Non-specific effects of methyl ketone peptide inhibitors of caspases. FEBS Lett. 1999; 442:117-121. [PubMed: 9923616]

Schweichel JU, Merker HJ. The morphology of various types of cell death in prenatal tissues. Teratology. 1973; 7:253-266. [PubMed: 4807128]

Schworer CM, Mortimore GE. Glucagon-induced autophagy and proteolysis in rat liver: mediation by selective deprivation of intracellular amino acids. Proc Natl Acad Sci U S A. 1979; 76:31693173. [PubMed: 290994]

Seglen PO, Gordon PB. 3-Methyladenine: specific inhibitor of autophagic/lysosomal protein degradation in isolated rat hepatocytes. Proc Natl Acad Sci U S A. 1982; 79:1889-1892. [PubMed: 6952238]

Shembade N, Ma A, Harhaj EW. Inhibition of NF-kappaB signaling by A20 through disruption of ubiquitin enzyme complexes. Science. 2010; 327:1135-1139. [PubMed: 20185725]

Shiffman ML, Pockros P, McHutchison JG, Schiff ER, Morris M, Burgess G. Clinical trial: the efficacy and safety of oral PF-03491390, a pancaspase inhibitor - a randomized placebocontrolled study in patients with chronic hepatitis C. Aliment Pharmacol Ther. 2010; 31:969978. [PubMed: 20163376]

Sieving PA, Chaudhry P, Kondo M, Provenzano M, Wu D, Carlson TJ, Bush RA, Thompson DA. Inhibition of the visual cycle in vivo by 13-cis retinoic acid protects from light damage and provides a mechanism for night blindness in isotretinoin therapy. Proc Natl Acad Sci U S A. 2001; 98:1835-1840. [PubMed: 11172037]

Sotelo J, Briceno E, Lopez-Gonzalez MA. Adding chloroquine to conventional treatment for glioblastoma multiforme: a randomized, double-blind, placebo-controlled trial. Annals of internal medicine. 2006; 144:337-343. [PubMed: 16520474]

Stanger BZ, Leder P, Lee TH, Kim E, Seed B. RIP: a novel protein containing a death domain that interacts with Fas/APO-1 (CD95) in yeast and causes cell death. Cell. 1995; 81:513-523. [PubMed: 7538908]

Sumimoto H. Structure, regulation and evolution of Nox-family NADPH oxidases that produce reactive oxygen species. FEBS J. 2008; 275:3249-3277. [PubMed: 18513324]

Sun L, Wang H, Wang Z, He S, Chen S, Liao D, Wang L, Yan J, Liu W, Lei X, Wang X. Mixed lineage kinase domain-like protein mediates necrosis signaling downstream of RIP3 kinase. Cell. 2012; 148:213-227. [PubMed: 22265413]

Sun X, Lee J, Navas T, Baldwin DT, Stewart TA, Dixit VM. RIP3, a novel apoptosis-inducing kinase. J Biol Chem. 1999; 274:16871-16875. [PubMed: 10358032] 
Sun X, Yin J, Starovasnik MA, Fairbrother WJ, Dixit VM. Identification of a novel homotypic interaction motif required for the phosphorylation of receptor-interacting protein (RIP) by RIP3. J Biol Chem. 2002; 277:9505-9511. [PubMed: 11734559]

Susin SA, Lorenzo HK, Zamzami N, Marzo I, Snow BE, Brothers GM, Mangion J, Jacotot E, Costantini P, Loeffler M, Larochette N, Goodlett DR, Aebersold R, Siderovski DP, Penninger JM, Kroemer G. Molecular characterization of mitochondrial apoptosis-inducing factor. Nature. 1999; 397:441-446. [PubMed: 9989411]

Suzuki M, Youle RJ, Tjandra N. Structure of Bax: coregulation of dimer formation and intracellular localization. Cell. 2000; 103:645-654. [PubMed: 11106734]

Suzuki T, Nakagawa M, Yoshikawa A, Sasagawa N, Yoshimori T, Ohsumi Y, Nishino I, Ishiura S, Nonaka I. The first molecular evidence that autophagy relates rimmed vacuole formation in chloroquine myopathy. Journal of biochemistry. 2002; 131:647-651. [PubMed: 11983070]

Szamier RB, Berson EL. Retinal ultrastructure in advanced retinitis pigmentosa. Invest Ophthalmol Vis Sci. 1977; 16:947-962. [PubMed: 908648]

Tait SW, Green DR. Mitochondria and cell death: outer membrane permeabilization and beyond. Nat Rev Mol Cell Biol. 2010; 11:621-632. [PubMed: 20683470]

Takahashi N, Duprez L, Grootjans S, Cauwels A, Nerinckx W, Duhadaway JB, Goossens V, Roelandt R, Van Hauwermeiren F, Libert C, Declercq W, Callewaert N, Prendergast GC, Degterev A, Yuan J, Vandenabeele P. Necrostatin-1 analogues: critical issues on the specificity, activity and in vivo use in experimental disease models. Cell Death Dis. 2012; 3:e437. [PubMed: 23190609]

Tanida I, Minematsu-Ikeguchi N, Ueno T, Kominami E. Lysosomal turnover, but not a cellular level, of endogenous LC3 is a marker for autophagy. Autophagy. 2005; 1:84-91. [PubMed: 16874052]

Tarallo V, Hirano Y, Gelfand BD, Dridi S, Kerur N, Kim Y, Cho WG, Kaneko H, Fowler BJ, Bogdanovich S, Albuquerque RJ, Hauswirth WW, Chiodo VA, Kugel JF, Goodrich JA, Ponicsan SL, Chaudhuri G, Murphy MP, Dunaief JL, Ambati BK, Ogura Y, Yoo JW, Lee DK, Provost P, Hinton DR, Nunez G, Baffi JZ, Kleinman ME, Ambati J. DICER1 loss and Alu RNA induce age-related macular degeneration via the NLRP3 inflammasome and MyD88. Cell. 2012; 149:847-859. [PubMed: 22541070]

Tata JR. Requirement for RNA and protein synthesis for induced regression of the tadpole tail in organ culture. Dev Biol. 1966; 13:77-94. [PubMed: 5923195]

Tenev T, Bianchi K, Darding M, Broemer M, Langlais C, Wallberg F, Zachariou A, Lopez J, MacFarlane M, Cain K, Meier P. The Ripoptosome, a signaling platform that assembles in response to genotoxic stress and loss of IAPs. Mol Cell. 2011; 43:432-448. [PubMed: 21737329]

Terni B, Rey MJ, Boluda S, Torrejon-Escribano B, Sabate MP, Calopa M, van Leeuwen FW, Ferrer I. Mutant ubiquitin and p62 immunoreactivity in cases of combined multiple system atrophy and Alzheimer's disease. Acta neuropathologica. 2007; 113:403-416. [PubMed: 17237936]

Thanos A, Morizane Y, Murakami Y, Giani A, Mantopoulos D, Kayama M, Roh MI, Michaud N, Pawlyk B, Sandberg M, Young LH, Miller JW, Vavvas DG. Evidence for baseline retinal pigment epithelium pathology in the Trp1-Cre mouse. Am J Pathol. 2012; 180:1917-1927. [PubMed: 22429967]

Thome M, Schneider P, Hofmann K, Fickenscher H, Meinl E, Neipel F, Mattmann C, Burns K, Bodmer JL, Schroter M, Scaffidi C, Krammer PH, Peter ME, Tschopp J. Viral FLICE-inhibitory proteins (FLIPs) prevent apoptosis induced by death receptors. Nature. 1997; 386:517-521. [PubMed: 9087414]

Thoreen CC, Kang SA, Chang JW, Liu Q, Zhang J, Gao Y, Reichling LJ, Sim T, Sabatini DM, Gray NS. An ATP-competitive mammalian target of rapamycin inhibitor reveals rapamycin-resistant functions of mTORC1. J Biol Chem. 2009; 284:8023-8032. [PubMed: 19150980]

Tinel A, Tschopp J. The PIDDosome, a protein complex implicated in activation of caspase-2 in response to genotoxic stress. Science. 2004; 304:843-846. [PubMed: 15073321]

Townsend KN, Hughson LR, Schlie K, Poon VI, Westerback A, Lum JJ. Autophagy inhibition in cancer therapy: metabolic considerations for antitumor immunity. Immunological reviews. 2012; 249:176-194. [PubMed: 22889222]

Trichonas G, Murakami Y, Thanos A, Morizane Y, Kayama M, Debouck CM, Hisatomi T, Miller JW, Vavvas DG. Receptor interacting protein kinases mediate retinal detachment-induced

Prog Retin Eye Res. Author manuscript; available in PMC 2014 November 01. 
photoreceptor necrosis and compensate for inhibition of apoptosis. Proc Natl Acad Sci U S A. 2010; 107:21695-21700. [PubMed: 21098270]

Trompouki E, Hatzivassiliou E, Tsichritzis T, Farmer H, Ashworth A, Mosialos G. CYLD is a deubiquitinating enzyme that negatively regulates NF-kappaB activation by TNFR family members. Nature. 2003; 424:793-796. [PubMed: 12917689]

Tsujimoto Y, Cossman J, Jaffe E, Croce CM. Involvement of the bcl-2 gene in human follicular lymphoma. Science. 1985; 228:1440-1443. [PubMed: 3874430]

Tsukada M, Ohsumi Y. Isolation and characterization of autophagy-defective mutants of Saccharomyces cerevisiae. FEBS Lett. 1993; 333:169-174. [PubMed: 8224160]

Ueda H, Fujita R, Yoshida A, Matsunaga H, Ueda M. Identification of prothymosin-alpha1, the necrosis-apoptosis switch molecule in cortical neuronal cultures. J Cell Biol. 2007; 176:853-862. [PubMed: 17353361]

Ueki Y, Le YZ, Chollangi S, Muller W, Ash JD. Preconditioning-induced protection of photoreceptors requires activation of the signal-transducing receptor gp130 in photoreceptors. Proc Natl Acad Sci U S A. 2009; 106:21389-21394. [PubMed: 19948961]

Upton JW, Kaiser WJ, Mocarski ES. Cytomegalovirus M45 cell death suppression requires receptorinteracting protein (RIP) homotypic interaction motif (RHIM)-dependent interaction with RIP1. J Biol Chem. 2008; 283:16966-16970. [PubMed: 18442983]

Upton JW, Kaiser WJ, Mocarski ES. Virus inhibition of RIP3-dependent necrosis. Cell Host Microbe. 2010; 7:302-313. [PubMed: 20413098]

Vahsen N, Cande C, Briere JJ, Benit P, Joza N, Larochette N, Mastroberardino PG, Pequignot MO, Casares N, Lazar V, Feraud O, Debili N, Wissing S, Engelhardt S, Madeo F, Piacentini M, Penninger JM, Schagger H, Rustin P, Kroemer G. AIF deficiency compromises oxidative phosphorylation. Embo J. 2004; 23:4679-4689. [PubMed: 15526035]

Valentino KL, Gutierrez M, Sanchez R, Winship MJ, Shapiro DA. First clinical trial of a novel caspase inhibitor: anti-apoptotic caspase inhibitor, IDN-6556, improves liver enzymes. Int J Clin Pharmacol Ther. 2003; 41:441-449. [PubMed: 14703949]

van Raam BJ, Salvesen GS. Proliferative versus apoptotic functions of caspase-8 Hetero or homo: the caspase-8 dimer controls cell fate. Biochim Biophys Acta. 2012; 1824:113-122. [PubMed: 21704196]

Vandenabeele P, Galluzzi L, Vanden Berghe T, Kroemer G. Molecular mechanisms of necroptosis: an ordered cellular explosion. Nat Rev Mol Cell Biol. 2010; 11:700-714. [PubMed: 20823910]

Vanlangenakker N, Vanden Berghe T, Bogaert P, Laukens B, Zobel K, Deshayes K, Vucic D, Fulda S, Vandenabeele P, Bertrand MJ. cIAP1 and TAK1 protect cells from TNF-induced necrosis by preventing RIP1/RIP3-dependent reactive oxygen species production. Cell Death Differ. 2010; 18:656-665. [PubMed: 21052097]

Varfolomeev E, Goncharov T, Fedorova AV, Dynek JN, Zobel K, Deshayes K, Fairbrother WJ, Vucic D. c-IAP1 and c-IAP2 are critical mediators of tumor necrosis factor alpha (TNFalpha)-induced NF-kappaB activation. J Biol Chem. 2008; 283:24295-24299. [PubMed: 18621737]

Varfolomeev EE, Schuchmann M, Luria V, Chiannilkulchai N, Beckmann JS, Mett IL, Rebrikov D, Brodianski VM, Kemper OC, Kollet O, Lapidot T, Soffer D, Sobe T, Avraham KB, Goncharov T, Holtmann H, Lonai P, Wallach D. Targeted disruption of the mouse Caspase 8 gene ablates cell death induction by the TNF receptors, Fas/Apo1, and DR3 and is lethal prenatally. Immunity. 1998; 9:267-276. [PubMed: 9729047]

Vaux DL, Cory S, Adams JM. Bcl-2 gene promotes haemopoietic cell survival and cooperates with cmyc to immortalize pre-B cells. Nature. 1988; 335:440-442. [PubMed: 3262202]

Vercammen D, Beyaert R, Denecker G, Goossens V, Van Loo G, Declercq W, Grooten J, Fiers W, Vandenabeele P. Inhibition of caspases increases the sensitivity of L929 cells to necrosis mediated by tumor necrosis factor. J Exp Med. 1998a; 187:1477-1485. [PubMed: 9565639]

Vercammen D, Brouckaert G, Denecker G, Van de Craen M, Declercq W, Fiers W, Vandenabeele P. Dual signaling of the Fas receptor: initiation of both apoptotic and necrotic cell death pathways. J Exp Med. 1998b; 188:919-930. [PubMed: 9730893]

Prog Retin Eye Res. Author manuscript; available in PMC 2014 November 01. 
Verhagen AM, Ekert PG, Pakusch M, Silke J, Connolly LM, Reid GE, Moritz RL, Simpson RJ, Vaux DL. Identification of DIABLO, a mammalian protein that promotes apoptosis by binding to and antagonizing IAP proteins. Cell. 2000; 102:43-53. [PubMed: 10929712]

Vince JE, Wong WW, Gentle I, Lawlor KE, Allam R, O’Reilly L, Mason K, Gross O, Ma S, Guarda G, Anderton H, Castillo R, Hacker G, Silke J, Tschopp J. Inhibitor of apoptosis proteins limit RIP3 kinase-dependent interleukin-1 activation. Immunity. 2012; 36:215-227. [PubMed: 22365665]

Wakabayashi T, Oshima Y, Fujimoto H, Murakami Y, Sakaguchi H, Kusaka S, Tano Y. Foveal microstructure and visual acuity after retinal detachment repair: imaging analysis by Fourierdomain optical coherence tomography. Ophthalmology. 2009; 116:519-528. [PubMed: 19147231]

Wang CY, Mayo MW, Korneluk RG, Goeddel DV, Baldwin AS Jr. NF-kappaB antiapoptosis: induction of TRAF1 and TRAF2 and c-IAP1 and c-IAP2 to suppress caspase- 8 activation. Science. 1998; 281:1680-1683. [PubMed: 9733516]

Wang AL, Lukas TJ, Yuan M, Du N, Tso MO, Neufeld AH. Autophagy and exosomes in the aged retinal pigment epithelium: possible relevance to drusen formation and age-related macular degeneration. PLoS One. 2009; 4:e4160. [PubMed: 19129916]

Wang H, Bloom O, Zhang M, Vishnubhakat JM, Ombrellino M, Che J, Frazier A, Yang H, Ivanova S, Borovikova L, Manogue KR, Faist E, Abraham E, Andersson J, Andersson U, Molina PE, Abumrad NN, Sama A, Tracey KJ. HMG-1 as a late mediator of endotoxin lethality in mice. Science. 1999; 285:248-251. [PubMed: 10398600]

Wang T, Lao U, Edgar BA. TOR-mediated autophagy regulates cell death in Drosophila neurodegenerative disease. J Cell Biol. 2009; 186:703-711. [PubMed: 19720874]

Wang Z, Jiang H, Chen S, Du F, Wang X. The mitochondrial phosphatase PGAM5 functions at the convergence point of multiple necrotic death pathways. Cell. 2012; 148:228-243. [PubMed: 22265414]

Weaver JG, Tarze A, Moffat TC, Lebras M, Deniaud A, Brenner C, Bren GD, Morin MY, Phenix BN, Dong L, Jiang SX, Sim VL, Zurakowski B, Lallier J, Hardin H, Wettstein P, van Heeswijk RP, Douen A, Kroemer RT, Hou ST, Bennett SA, Lynch DH, Kroemer G, Badley AD. Inhibition of adenine nucleotide translocator pore function and protection against apoptosis in vivo by an HIV protease inhibitor. J Clin Invest. 2005; 115:1828-1838. [PubMed: 15937550]

Welz PS, Wullaert A, Vlantis K, Kondylis V, Fernandez-Majada V, Ermolaeva M, Kirsch P, SternerKock A, van Loo G, Pasparakis M. FADD prevents RIP3-mediated epithelial cell necrosis and chronic intestinal inflammation. Nature. 2011; 477:330-334. [PubMed: 21804564]

Wenzel A, Grimm C, Samardzija M, Reme CE. Molecular mechanisms of light-induced photoreceptor apoptosis and neuroprotection for retinal degeneration. Prog Retin Eye Res. 2005; 24:275-306. [PubMed: 15610977]

Wertz IE, O'Rourke KM, Zhou H, Eby M, Aravind L, Seshagiri S, Wu P, Wiesmann C, Baker R, Boone DL, Ma A, Koonin EV, Dixit VM. De-ubiquitination and ubiquitin ligase domains of A20 downregulate NF-kappaB signalling. Nature. 2004; 430:694-699. [PubMed: 15258597]

Williams A, Jahreiss L, Sarkar S, Saiki S, Menzies FM, Ravikumar B, Rubinsztein DC. Aggregateprone proteins are cleared from the cytosol by autophagy: therapeutic implications. Current topics in developmental biology. 2006; 76:89-101. [PubMed: 17118264]

Wong WT, Dresner S, Forooghian F, Glaser T, Doss L, Zhou M, Cunningham D, Shimel K, Harrington M, Hammel K, Cukras CA, Ferris FL, Chew EY. Treatment of geographic atrophy with subconjunctival sirolimus: results of a phase I/II clinical trial. Invest Ophthalmol Vis Sci. 2013; 54:2941-2950. [PubMed: 23548622]

Wright A, Reiley WW, Chang M, Jin W, Lee AJ, Zhang M, Sun SC. Regulation of early wave of germ cell apoptosis and spermatogenesis by deubiquitinating enzyme CYLD. Dev Cell. 2007; 13:705716. [PubMed: 17981138]

Wright AF, Chakarova CF, Abd El-Aziz MM, Bhattacharya SS. Photoreceptor degeneration: genetic and mechanistic dissection of a complex trait. Nat Rev Genet. 2010; 11:273-284. [PubMed: 20212494]

Prog Retin Eye Res. Author manuscript; available in PMC 2014 November 01. 
Wright KM, Linhoff MW, Potts PR, Deshmukh M. Decreased apoptosome activity with neuronal differentiation sets the threshold for strict IAP regulation of apoptosis. J Cell Biol. 2004; 167:303-313. [PubMed: 15504912]

Xu Y, Huang S, Liu ZG, Han J. Poly(ADP-ribose) polymerase-1 signaling to mitochondria in necrotic cell death requires RIP1/TRAF2-mediated JNK1 activation. J Biol Chem. 2006; 281:8788-8795. [PubMed: 16446354]

Yakovlev AG, Ota K, Wang G, Movsesyan V, Bao WL, Yoshihara K, Faden AI. Differential expression of apoptotic protease-activating factor-1 and caspase-3 genes and susceptibility to apoptosis during brain development and after traumatic brain injury. J Neurosci. 2001; 21:74397446. [PubMed: 11567033]

Yamamoto A, Tagawa Y, Yoshimori T, Moriyama Y, Masaki R, Tashiro Y. Bafilomycin A1 prevents maturation of autophagic vacuoles by inhibiting fusion between autophagosomes and lysosomes in rat hepatoma cell line, H-4-II-E cells. Cell structure and function. 1998; 23:33-42. [PubMed: 9639028]

Yang H, Ochani M, Li J, Qiang X, Tanovic M, Harris HE, Susarla SM, Ulloa L, Wang H, DiRaimo R, Czura CJ, Roth J, Warren HS, Fink MP, Fenton MJ, Andersson U, Tracey KJ. Reversing established sepsis with antagonists of endogenous high-mobility group box 1. Proc Natl Acad Sci U S A. 2004a; 101:296-301. [PubMed: 14695889]

Yang L, Bula D, Arroyo JG, Chen DF. Preventing retinal detachment-associated photoreceptor cell loss in Bax-deficient mice. Invest Ophthalmol Vis Sci. 2004b; 45:648-654. [PubMed: 14744910]

Yang P, Peairs JJ, Tano R, Zhang N, Tyrell J, Jaffe GJ. Caspase-8-mediated apoptosis in human RPE cells. Invest Ophthalmol Vis Sci. 2007; 48:3341-3349. [PubMed: 17591907]

Yaung J, Jin M, Barron E, Spee C, Wawrousek EF, Kannan R, Hinton DR. alpha-Crystallin distribution in retinal pigment epithelium and effect of gene knockouts on sensitivity to oxidative stress. Mol Vis. 2007; 13:566-577. [PubMed: 17438522]

Yaung J, Kannan R, Wawrousek EF, Spee C, Sreekumar PG, Hinton DR. Exacerbation of retinal degeneration in the absence of alpha crystallins in an in vivo model of chemically induced hypoxia. Exp Eye Res. 2008; 86:355-365. [PubMed: 18191123]

Yazdanpanah B, Wiegmann K, Tchikov V, Krut O, Pongratz C, Schramm M, Kleinridders A, Wunderlich T, Kashkar H, Utermohlen O, Bruning JC, Schutze S, Kronke M. Riboflavin kinase couples TNF receptor 1 to NADPH oxidase. Nature. 2009; 460:1159-1163. [PubMed: 19641494]

Yeh WC, Itie A, Elia AJ, Ng M, Shu HB, Wakeham A, Mirtsos C, Suzuki N, Bonnard M, Goeddel DV, Mak TW. Requirement for Casper (c-FLIP) in regulation of death receptor-induced apoptosis and embryonic development. Immunity. 2000; 12:633-642. [PubMed: 10894163]

Yeh WC, Pompa JL, McCurrach ME, Shu HB, Elia AJ, Shahinian A, Ng M, Wakeham A, Khoo W, Mitchell K, El-Deiry WS, Lowe SW, Goeddel DV, Mak TW. FADD: essential for embryo development and signaling from some, but not all, inducers of apoptosis. Science. 1998; 279:1954-1958. [PubMed: 9506948]

Yoshida T, Ohno-Matsui K, Ichinose S, Sato T, Iwata N, Saido TC, Hisatomi T, Mochizuki M, Morita I. The potential role of amyloid beta in the pathogenesis of age-related macular degeneration. $\mathrm{J}$ Clin Invest. 2005; 115:2793-2800. [PubMed: 16167083]

Yoshimura T, Sonoda KH, Sugahara M, Mochizuki Y, Enaida H, Oshima Y, Ueno A, Hata Y, Yoshida $\mathrm{H}$, Ishibashi T. Comprehensive analysis of inflammatory immune mediators in vitreoretinal diseases. PLoS One. 2009; 4:e8158. [PubMed: 19997642]

Yoshizawa K, Kiuchi K, Nambu H, Yang J, Senzaki H, Kiyozuka Y, Shikata N, Tsubura A. Caspase-3 inhibitor transiently delays inherited retinal degeneration in $\mathrm{C} 3 \mathrm{H}$ mice carrying the rd gene. Graefes Arch Clin Exp Ophthalmol. 2002; 240:214-219. [PubMed: 11935279]

You Z, Savitz SI, Yang J, Degterev A, Yuan J, Cuny GD, Moskowitz MA, Whalen MJ. Necrostatin-1 reduces histopathology and improves functional outcome after controlled cortical impact in mice. J Cereb Blood Flow Metab. 2008; 28:1564-1573. [PubMed: 18493258]

Yu JW, Shi Y. FLIP and the death effector domain family. Oncogene. 2008; 27:6216-6227. [PubMed: 18931689]

Prog Retin Eye Res. Author manuscript; available in PMC 2014 November 01. 
Yu L, Alva A, Su H, Dutt P, Freundt E, Welsh S, Baehrecke EH, Lenardo MJ. Regulation of an ATG7-beclin 1 program of autophagic cell death by caspase-8. Science. 2004; 304:1500-1502. [PubMed: 15131264]

Yu L, Wan F, Dutta S, Welsh S, Liu Z, Freundt E, Baehrecke EH, Lenardo M. Autophagic programmed cell death by selective catalase degradation. Proc Natl Acad Sci U S A. 2006a; 103:4952-4957. [PubMed: 16547133]

Yu SW, Andrabi SA, Wang H, Kim NS, Poirier GG, Dawson TM, Dawson VL. Apoptosis-inducing factor mediates poly(ADP-ribose) (PAR) polymer-induced cell death. Proc Natl Acad Sci U S A. 2006b; 103:18314-18319. [PubMed: 17116881]

Yu SW, Wang H, Poitras MF, Coombs C, Bowers WJ, Federoff HJ, Poirier GG, Dawson TM, Dawson VL. Mediation of poly(ADP-ribose) polymerase-1-dependent cell death by apoptosis-inducing factor. Science. 2002; 297:259-263. [PubMed: 12114629]

Yuan J, Shaham S, Ledoux S, Ellis HM, Horvitz HR. The C. elegans cell death gene ced-3 encodes a protein similar to mammalian interleukin-1 beta-converting enzyme. Cell. 1993; 75:641-652. [PubMed: 8242740]

Zacks DN, Boehlke C, Richards AL, Zheng QD. Role of the Fas-signaling pathway in photoreceptor neuroprotection. Arch Ophthalmol. 2007; 125:1389-1395. [PubMed: 17923548]

Zacks DN, Han Y, Zeng Y, Swaroop A. Activation of signaling pathways and stress-response genes in an experimental model of retinal detachment. Invest Ophthalmol Vis Sci. 2006; 47:1691-1695. [PubMed: 16565410]

Zacks DN, Hanninen V, Pantcheva M, Ezra E, Grosskreutz C, Miller JW. Caspase activation in an experimental model of retinal detachment. Invest Ophthalmol Vis Sci. 2003; 44:1262-1267. [PubMed: 12601057]

Zacks DN, Zheng QD, Han Y, Bakhru R, Miller JW. FAS-mediated apoptosis and its relation to intrinsic pathway activation in an experimental model of retinal detachment. Invest Ophthalmol Vis Sci. 2004; 45:4563-4569. [PubMed: 15557468]

Zeiss CJ, Neal J, Johnson EA. Caspase-3 in postnatal retinal development and degeneration. Invest Ophthalmol Vis Sci. 2004; 45:964-970. [PubMed: 14985318]

Zhang DW, Shao J, Lin J, Zhang N, Lu BJ, Lin SC, Dong MQ, Han J. RIP3, an energy metabolism regulator that switches TNF-induced cell death from apoptosis to necrosis. Science. 2009a; 325:332-336. [PubMed: 19498109]

Zhang H, Zhou X, McQuade T, Li J, Chan FK, Zhang J. Functional complementation between FADD and RIP1 in embryos and lymphocytes. Nature. 2011; 471:373-376. [PubMed: 21368761]

Zhang Y, Xing D, Liu L. PUMA promotes Bax translocation by both directly interacting with Bax and by competitive binding to Bcl-X L during UV-induced apoptosis. Mol Biol Cell. 2009b; 20:3077-3087. [PubMed: 19439449]

Zheng L, Anderson RE, Agbaga MP, Rucker EB 3rd, Le YZ. Loss of BCL-XL in rod photoreceptors: Increased susceptibility to bright light stress. Invest Ophthalmol Vis Sci. 2006; 47:5583-5589. [PubMed: 17122152]

Zhu C, Wang X, Deinum J, Huang Z, Gao J, Modjtahedi N, Neagu MR, Nilsson M, Eriksson PS, Hagberg H, Luban J, Kroemer G, Blomgren K. Cyclophilin A participates in the nuclear translocation of apoptosis-inducing factor in neurons after cerebral hypoxia-ischemia. J Exp Med. 2007; 204:1741-1748. [PubMed: 17635954]

Zhu S, Zhang Y, Bai G, Li H. Necrostatin-1 ameliorates symptoms in R6/2 transgenic mouse model of Huntington's disease. Cell Death Dis. 2011; 2:e115. [PubMed: 21359116]

Zitvogel L, Kepp O, Kroemer G. Decoding cell death signals in inflammation and immunity. Cell. 2010; 140:798-804. [PubMed: 20303871]

Prog Retin Eye Res. Author manuscript; available in PMC 2014 November 01. 
A

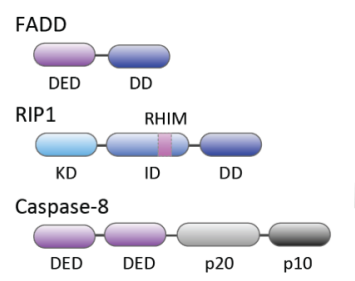

Apaf-1

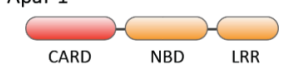

Caspase-9
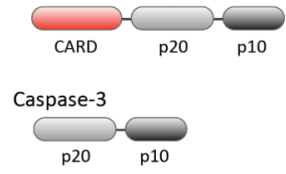

NLRP3

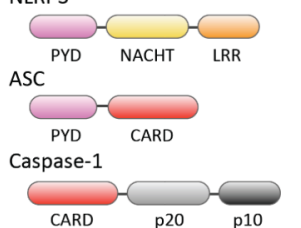

B

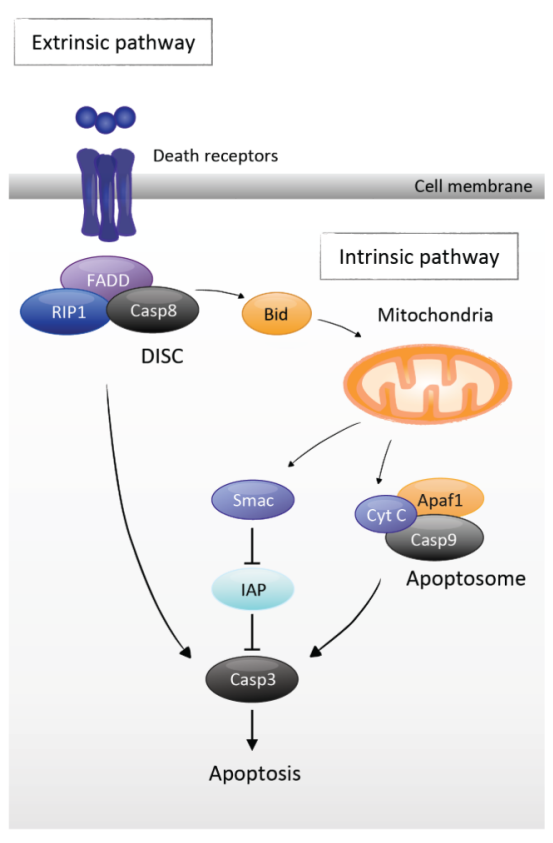

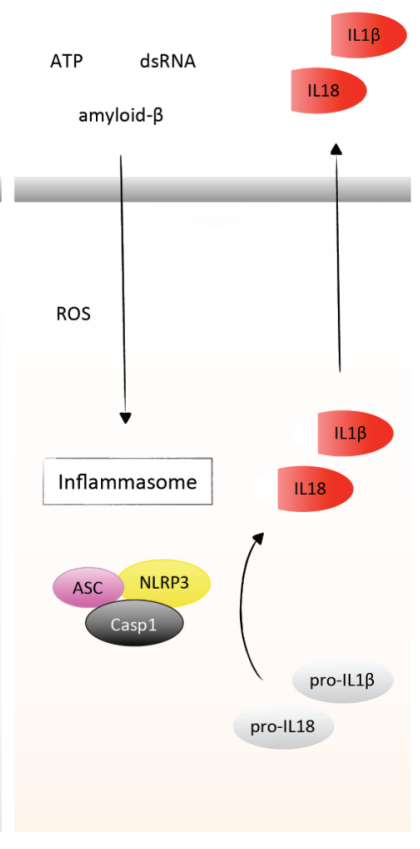

Figure 1. Caspase signaling

A. The structure of caspase family proteins and components of DISC and apoptosome. DED, Death effector domain; DD, Death domain; KD, Kinase domain; ID, Intermediate domain; RHIM, RIP homotypic interaction motif; p20, p20 subunit; p10, p10 subunit; CARD, Caspase activation and recruit domain; NBD, Nucleotide binding domain; LRR, Leucine rich repeats; PYD, Pyrin domain; NACHT, NAIP (neuronal apoptosis inhibitory protein), CIITA (MHC class II transcription activator), HET-E (incompatibility locus protein from Podospora anserina) and TP1 (telomerase-associated protein) domain.

B. The extrinsic pathway is initiated by the biding of death ligands to their cell-surface death receptors. The death domains of these receptors recruit adaptor molecules such as FADD and caspase-8. Multimerization of caspase- 8 in the DISC leads to its activation and cleavage of the downstream effector caspases such as caspase-3. On the other hand, the intrinsic pathway is triggered by the release of pro-apoptotic proteins from the mitochondria. Released cytochrome $c$ forms the apoptosome with Apaf-1 and caspase-9. Additionally, released Smac enhances caspase activation through the neutralization of IAP proteins. Of note, there is a cross-talk between the extrinsic and intrinsic pathways. Active caspase- 8 cleaves the $\mathrm{BH} 3$-only protein $\mathrm{Bid}$, which in turn initiates the release of mitochondrial proapoptotic proteins.

C. The inflammasome is formed in response to diverse danger signals such as ROS, ATP, amyloid- $\beta$ and dsRNA. Activation of caspase- 1 in the inflammasome leads to the cleavage of pro-IL $\beta$ and pro-IL18 into their mature pro-inflammatory forms and promotes their secretion. 
A
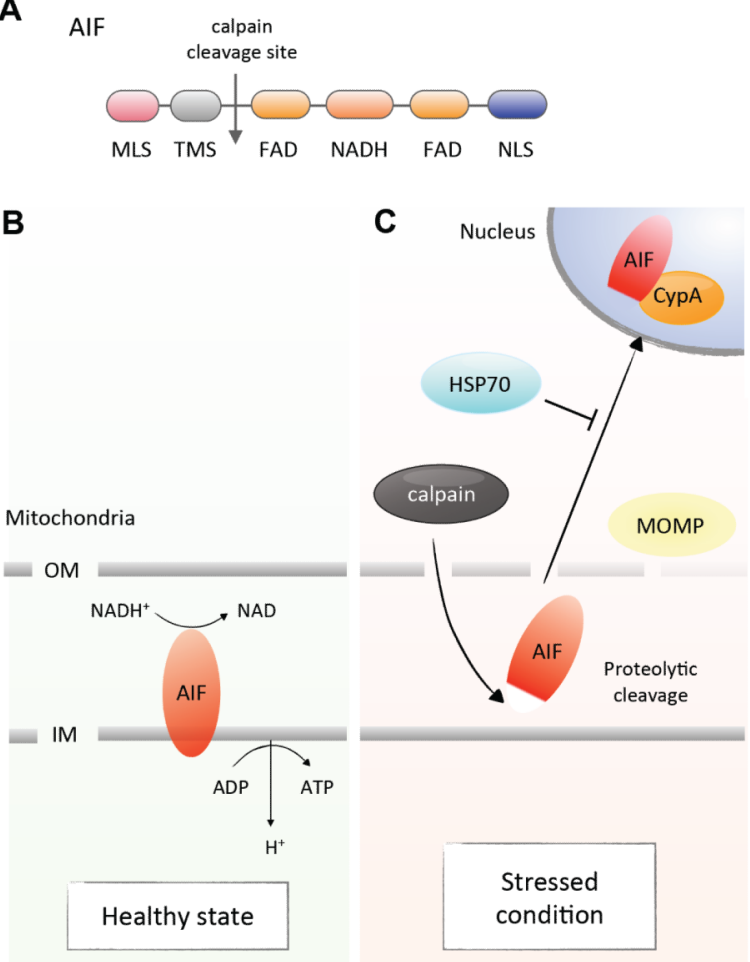

Figure 2. AIF signaling

A. The structure of AIF protein. MLS, mitochondrial localization sequence; TMS, transmembrane segment; FAD, flavin adenine dinucleotide-binding domain; NADH, nicotinamide adenine dinucleotide hydride-binding domain; NLS, nuclear localization sequence.

B. In healthy state, AIF is located in the mitochondrial inner membrane and modulates the vital mitochondrial function. AIF regulates the complex I activity, and thus is critical for the mitochondrial oxidative phosphorylation and cell survival.

C. In contrast, under stressed condition, AIF translocates from the mitochondria into the nucleus, where it functions as a caspase-independent inducer of cell death. The mitochondrial release of AIF proceeds by a two-step process: MOMP and proteolytic cleavage. Released AIF interacts with a number of proteins such as cyclophilin A and binds directly to DNA and RNA in the nucleus, thereby inducing chromatinolysis. 
A

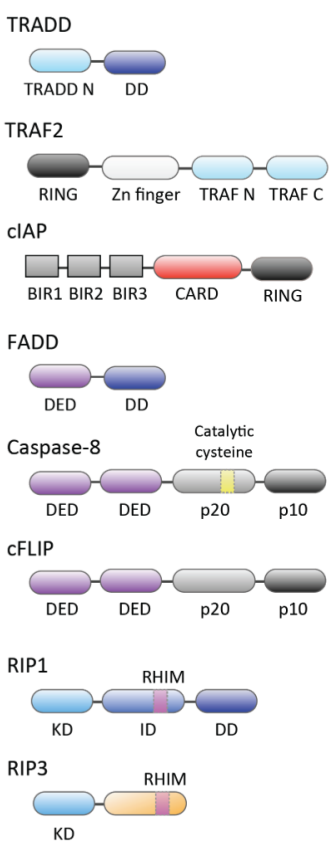

B

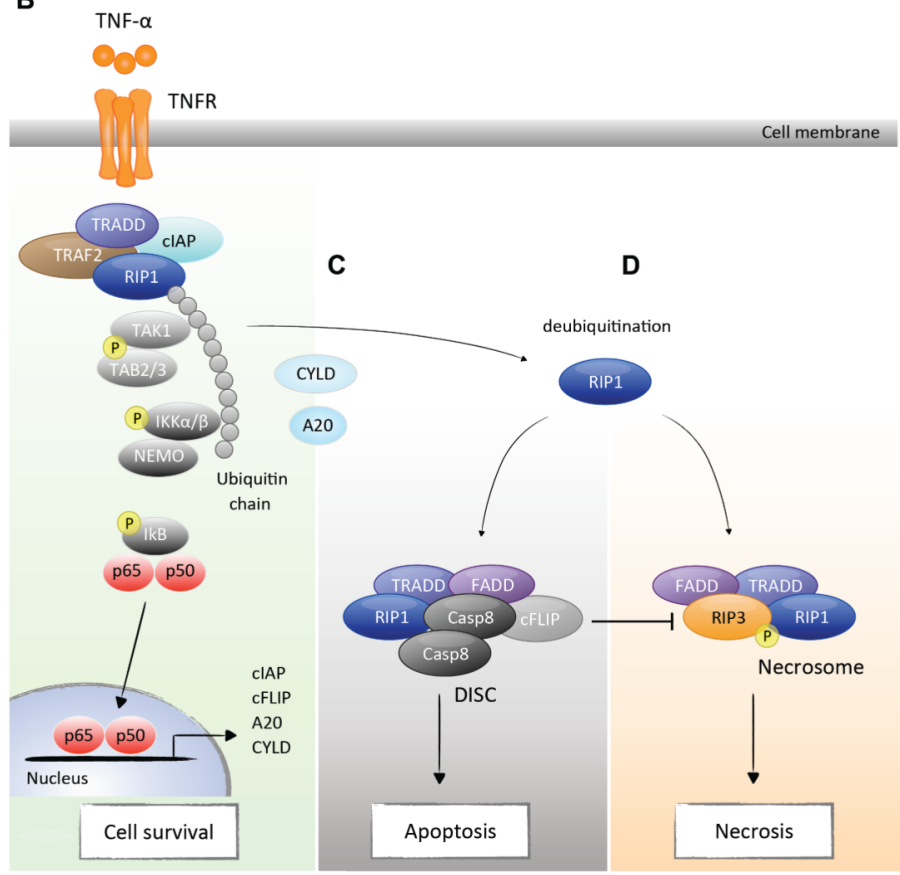

Figure 3. RIP signaling

A. The structure of RIP signaling components. TRADD N, TRADD N-terminal domain; DD, Death domain; RING, really interesting new gene domain; Zn finger, Zinc finger domain; TRAF N, TRAF N-terminal domain; TRAF C, TRAF C-terminal domain; BIR, Baculovirus IAP repeat domain; CARD, Caspase activation and recruit domain; DED, Death effector domain; p20, p20 subunit; p10, p10 subunit; KD, Kinase domain; ID, Intermediate domain; RHIM, RIP homotypic interaction motif.

B. In response to TNF-a stimulation, RIP1 is recruited to TNFR and forms a membrane associated complex with TRADD, TRAF2 and cIAPs. cIAPs ubiquitinate RIP1, which in turn mediate NF- $\kappa$ B activation. Nuclear translocation of $\mathrm{p} 65 / \mathrm{p} 50$ subunits promotes the production of pro-survival genes such as cIAPs and c-FLIPs as well as deubiquitinating enzymes such as CYLD and A20, which act as a negative feedback loop in NF- $\kappa \mathrm{B}$ signaling.

$\mathrm{C}$ and D. RIP1 switches its function to a regulator of cell death when it is deubiquitinated by CYLD or A20. Deubiquitination of RIP1 abolishes its ability to activate NF- $\kappa \mathrm{B}$, and leads to the formation of cytosolic pro-death complexes. These complexes contain TRADD, FADD, RIP1, caspase-8, c-FLIP and/or RIP3, and mediates either apoptosis or necrosis depending on cellular conditions. Multimerization of caspase- 8 in the DISC mediates a conformational change to its active form, thereby inducing apoptosis (C). The catalytic activity of caspase-8-c-FLIP heterodimer complex cleaves and inactivates RIP1 and RIP3. In conditions where caspases/c-FLIPs are inhibited or cannot be activated efficiently, RIP1 forms the necrosome with RIP3, thereby promoting necrosis (D). 


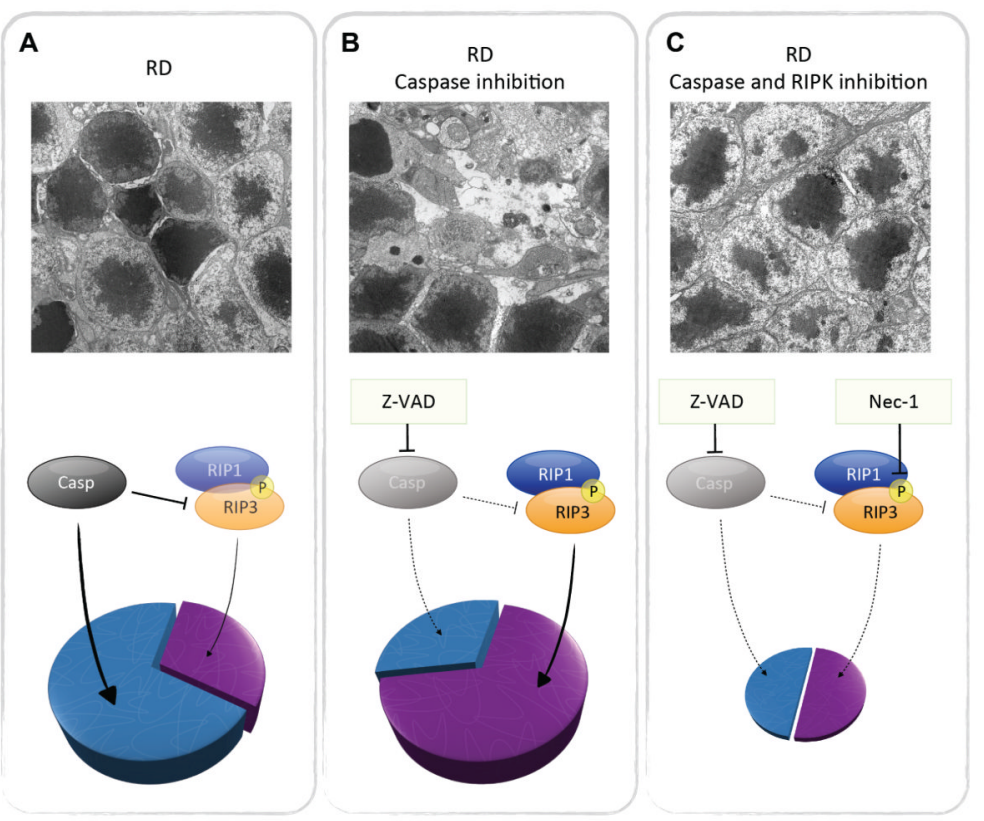

Figure 4. TEM findings and proposed mechanisms of photoreceptor cell death after RD A-C. TEM microphotographs show the outer nuclear layer of the mouse retina 3 days after RD. The eyes were treated with vehicle (A), Z-VAD (B) or Z-VAD plus Nec-1 (C). A: apoptotic cell. N: Necrotic cell. Scale bar, $5 \mu \mathrm{m}$. After RD, photoreceptor cell death occurs mainly through apoptosis (A). Caspase inhibition by the pan-caspase inhibitor Z-VAD decreases apoptosis but increases RIP kinase-dependent necrosis (B). Simultaneous blockade of both caspase and RIP kinase pathways provides efficient protection against photoreceptor cell loss (C). 


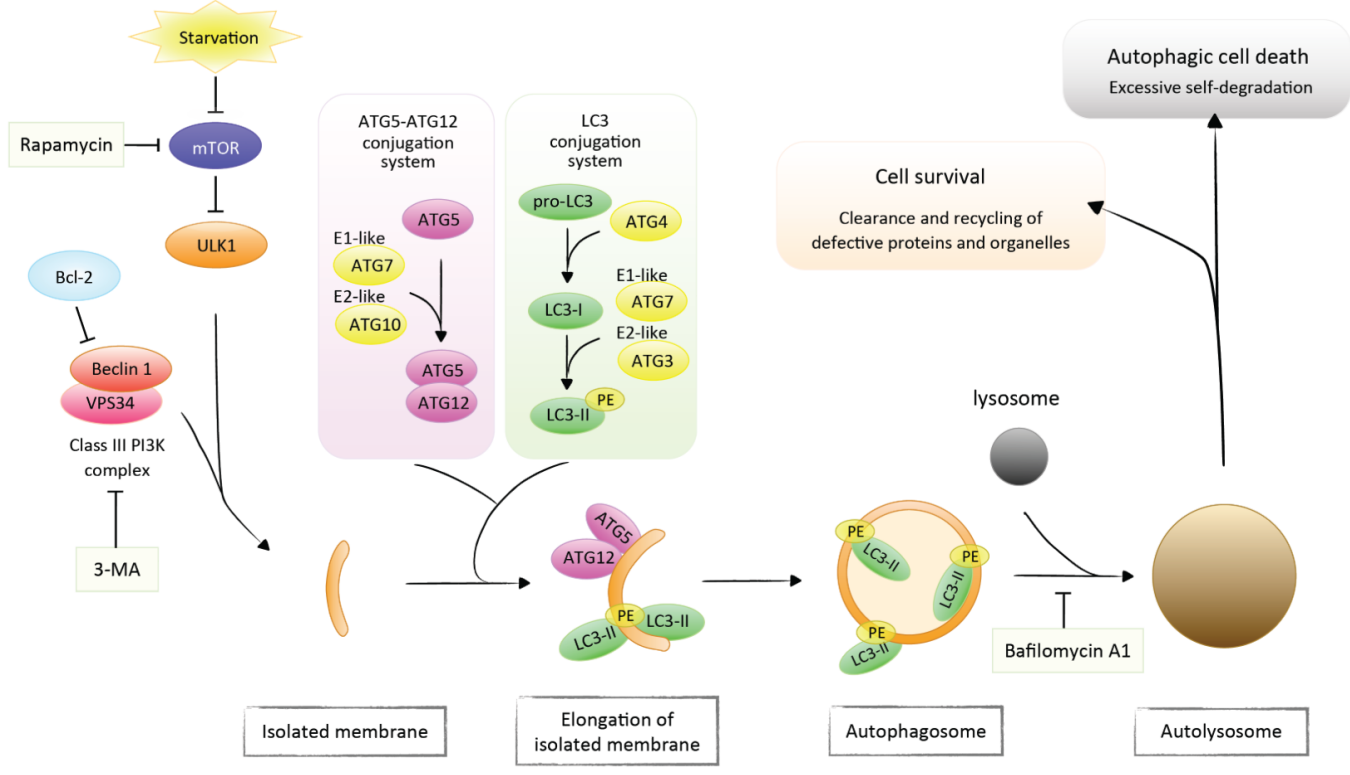

Figure 5. Autophagy signaling

Starvation activates autophagy through inhibition of mTOR, which negatively regulates ULK1 and Class III PI3-kinase. Activation of Class III PI3-kinase in the Beclin-1interacting complex is a key step in the formation of isolation membrane. Elongation of isolation membrane requires two ubiquitin-like conjugation systems: the Atg-5-Atg12 conjugation system and the LC3 conjugation system. Atg5-Atg12 complex and PEconjugated LC3 (LC3-II) are recruited to isolation membrane, and facilitate the formation of autophagosome. After fusion with lysosome, the autophagosomal content is degraded in the autolysosome. Autophagy is critical for cell survival by mediating the clearance and recycling of defective proteins and organelles. Nonetheless, autophagy also induces cell death via excessive self-degradation. 
A

Pro-survival Bcl-2 proteins (Bcl-2, Bcl-xL, etc.)

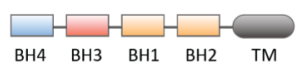

BH3-only Bcl-2 proteins (Bid, Bim, PUMA, Bmf, etc.)

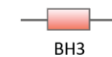

Multidomain pro-death $\mathrm{Bcl}-2$ proteins (Bax, Bak, etc.)

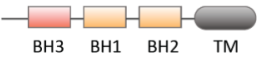

B

B

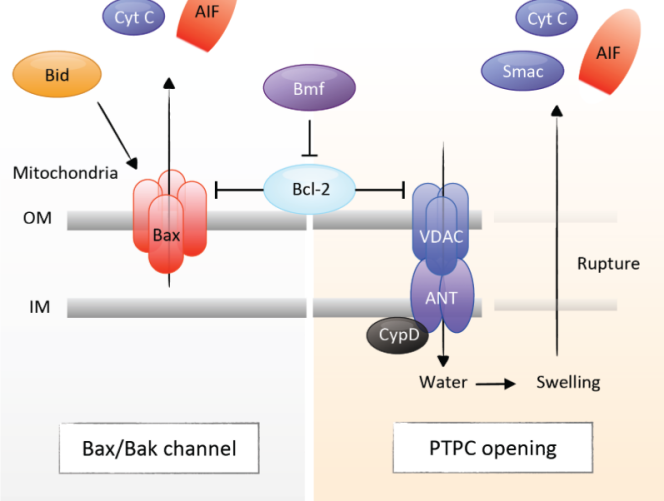

Figure 6. Regulation of MOMP

A. The structure of $\mathrm{Bcl}-2$ family proteins. $\mathrm{BH}, \mathrm{Bcl}-2$ homology domain; TM, transmembrane domain.

B. Bax/Bak are localized in the cytosol in normal conditions. However, on activation by BH3 only proteins, Bax and Bak undergo conformational change, leading to the oligomerization and translocation to the mitochondrial outer membrane. The formation of Bax/Bak channels allow for the release of cytochrome $c$ and other IMS proteins. C. PTPC is a polyprotein complex composed of VDAC, ANT and cyclophilin D. PTPC opening induces an influx of fluid into the matrix, which results in mitochondrial swelling and the rupture of mitochondrial outer membrane, thereby facilitating the non-selective release of mitochondrial proteins. 


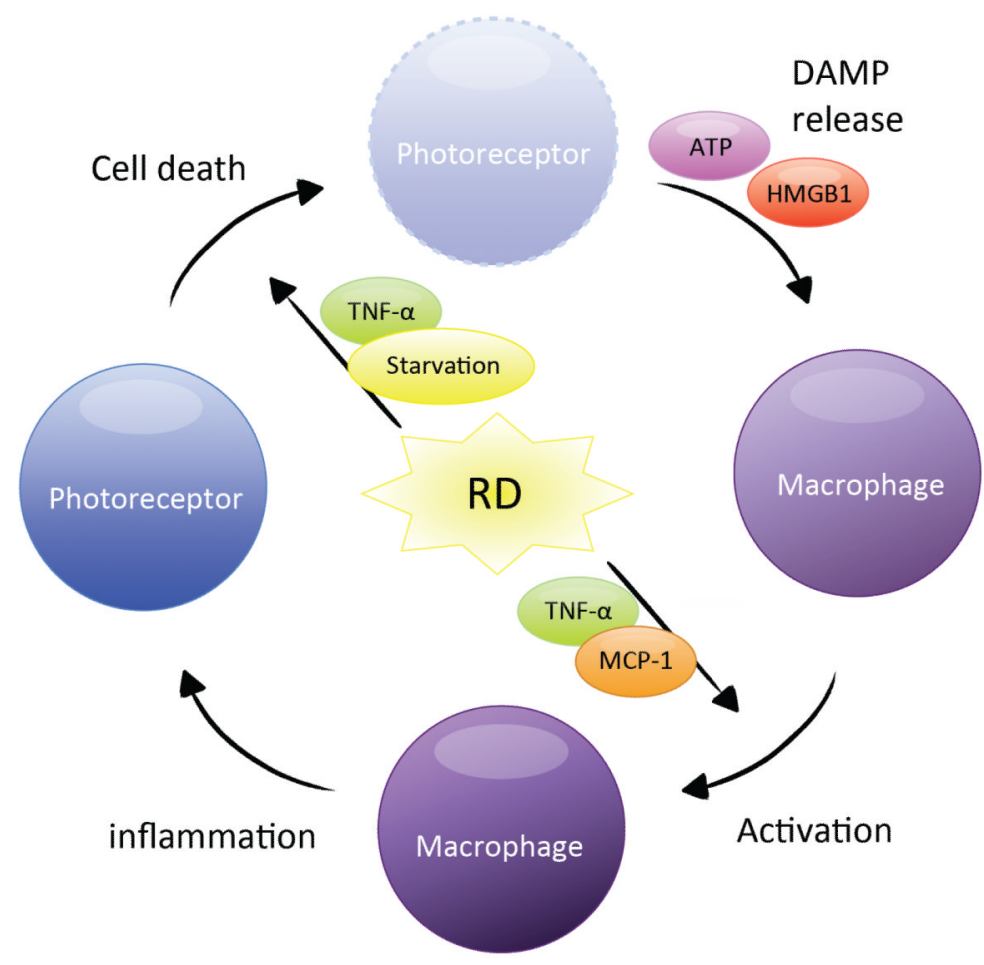

Figure 7. Inflammation and photoreceptor cell death

Cell death and Inflammation are interconnected. RD induces the production of cytokines and chemokines such as TNF-a and MCP-1, which mediate the activation of macrophages and microglial cells. Activated inflammatory cells infiltrate into the outer nuclear layer of the retina and stimulate photoreceptor cell death. Concomitantly, dying photoreceptor cells release numerous molecules such as ATP and HMGB1. These molecules are known as DAMPs, and amplify inflammatory response through the binding to TLRs and other cell surface receptors on inflammatory cells. 